\title{
A gyulladásos bélbetegségek patogenezisében szerepet játszó gének és mikroRNS-ek azonosítása módosított mintagyüjtéssel
}

Doktori értekezés

Boros Éva

Témavezető: Dr. Nagy István

Biológia Doktori Iskola

MTA SZBK Biokémiai Intézet

SZTE TTIK

2018.

Szeged 


\section{TARTALOMJEGYZÉK}

\section{RÖVIDÍTÉSEK JEGYZÉKE}

2. IRODALMI ÁTTEKINTÉS

2.1. A veleszületett immunitás 8

2.1.1. A veleszületett immunválasz aktiválása 8

2.1.2. A veleszületett immunrendszer végrehajtóinak toborzása 11

2.1.3. A veleszületett immunválasz sejtes komponensei 11

2.1.4. A veleszületett immunválasz szabályozása 13

2.1.5. A tápcsatorna immunrendszere 15

2.2. Immunmediált gyulladásos betegségek 18

2.3. A gyulladásos bélbetegségek - IBD 18

2.4. A gyulladásos bélbetegségek és a vastagbélrák kialakulása közötti összefüggés 19

2.4.1. Az epiteliális-mezenhimális tranzíció 21

2.5. A mikroRNS-ek szabályozó szerepe 23

2.5.1. A miRNS-ek biogenezise 23

2.5.2. A miRNS-ek biogenezisének kapcsolata a daganatokkal 25

2.5.3. miRNS-ek a daganatos megbetegedésekben és az EMT-ben 25

2.5.4. miRNS-ek a gyulladásos folyamatok szabályozásában 26

2.5.5. miRNS-ek alkalmazása a gyógyászatban 28

3. CÉLKITÜZÉSEK 30

4. ANYAGOK ÉS MÓDSZEREK

4.1. In vivo kísérleti modell és mintagyújtés 31

4.2. IBD-s betegek 31

4.3. RNS tisztítás 32

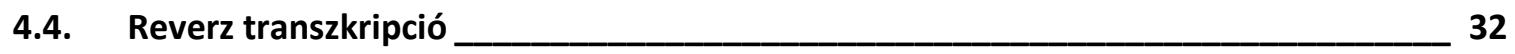

4.5. Valós idejü kvantitatív polimeráz láncreakció____ 33

4.6. miRNS valós idejü kvantitatív polimeráz láncreakció ____ 36

4.7. Teljes transzkriptóma szekvenálás (RNS szekvenálás; RNS-Seq) ___ 38

4.8. A RNS-Seq bioinformatikai kiértékelése ___ 38

4.9. Az RNS-Seq funkcionális analízise Ingenuity Pathway analysis (IPA) alkalmazással __ 39

4.10. Metszetkészítés és immunfluoreszcens festés___ 39 
4.11. Statisztikai analízis és ábrázolás

5. EREDMÉNYEK

5.1. A gyulladásos bélbetegségek vizsgálatára alkalmazott rendszerek 41

5.1.1. In vivo TNBS indukált patkány IBD modell 41

5.1.2. IBD-s betegek vastagbélmintáinak vizsgálata 42

5.2. TNBS által kiváltott in vivo IBD modell teljes transzkriptóma analízise 43

5.2.1. RNS-Seq és annak bioinformatikai feldolgozása 43

5.2.2. A teljes transzkripciós változások funkcionális analízise 45

5.3. A gyulladásos válasz szabályozása a vastagbélgyulladás in vivo modelljében és IBD-s betegek vastagbelében 50

5.3.1. Mintázat felismerő receptorok aktiválódása a gyulladt vastagbélben 50

5.3.2. A veleszületett immunitás sejtes komponenseinek toborzása 53

5.3.3. Az immunválasz negatív szabályozása 55

5.3.4. A nyálkahártya védelme 57

5.4. Az epiteliális-mezenhimális átmenet aktiválása a gyulladt szövetekben 63

5.5. A miRNS-ek szerepe a kísérletesen előidézett vastagbélgyulladásban és IBD-ben szenvedő betegek vastagbelében 67

5.5.1. Az immunválasz posztranszkripcionális szabályozása miRNS-ek által 70

5.5.2. Az IBD során indukálódott EMT szabályozása miRNS-ek által 73

6. DISZKUSSZIÓ 76

7. ÖSSZEFOGLALÓ 86

8. SUMMARY 90

9. KÖSZÖNETNYILVÁNÍTÁS 93

10. IRODALOMJEGYZÉK 94

11. FÜGGELÉK 102 


\section{RÖVIDÍTÉSEK JEGYZÉKE}

18S rRNA 18S ribosomal RNA (18S riboszómális RNS)

A4GNT $\quad \alpha 1,4-\mathrm{N}$-acetylgucosaminyltransferase ( $\alpha 1,4-\mathrm{N}$-acetilglükózamin transzferáz)

$\mathrm{AB} / \mathrm{AM} \quad$ antibiotic/antimycotic (antibiotikum/antimikotikum)

ABCA1 ATP binding cassette subfamily A member 1 (ATP kötő kazetta A1)

AGO2 argonaute 2, RISC catalytic component (RISC katalítikus alegység)

AIM2 absent in melanoma 2

AKT

AKT serine/threonine kinase (AKT szerin/treonin kináz)

ALR

AIM-like receptor (AIM - szerü receptor)

AXL

AXL receptor tyrosine kinase (AXL receptor tirozin kináz)

B4GALNT2 beta-1,4-N-acetyl-galactosaminyltransferase 2 (béta-1,4-N-acetilgalaktózamin transzferáz)

BCL2 BCL2, apoptosis regulator (BCL2 apoptózis szabályozó)

BMDM bone marrow-derived macrophages (csontvelői sejtekből differenciáltatott makrofágok)

CCL C-C motif chemokine ligand (CC kemokin ligand)

CD Crohn-disease (Crohn betegség)

$\mathrm{CDH} \quad$ cadherin (kadherin)

cDNS complementary DNA (komplementer DNS)

CXCL C-X-C motif chemokine ligand (CXC kemokin ligand)

CYP1B1 cytochrome P450 family 1 subfamily B member 1 (citokróm P450 1-es család B alcsalád 1)

DAMP danger-associated molecular pattern (veszély asszociált molekuláris mintázat)

DAPI 4,6-diamidino-2-phenylindole (4,6 diamidino-2-fenilindol)

DC dendritic cell (dendritikus sejt)

DGCR8 DGCR8, microprocessor complex subunit (DGCR8, mikroprocesszor komplex alegység)

DICER dicer 1, ribonuclease III (dicer1, 3-as típusú ribonukleáz)

DMBT1 deleted in malignant brain tumors 1

DNA deoxyribonucleic acid (dezoxiribonukleinsav, DNS)

DROSHA drosha ribonuclease III (drosha, 3-as típusú ribonukleáz)

ds double-stranded (kettős szálú)

ECM extracellular matrix (extracelluláris mátrix)

EGFR epidermal growth factor receptor (epidermális növekedési faktor receptor) 


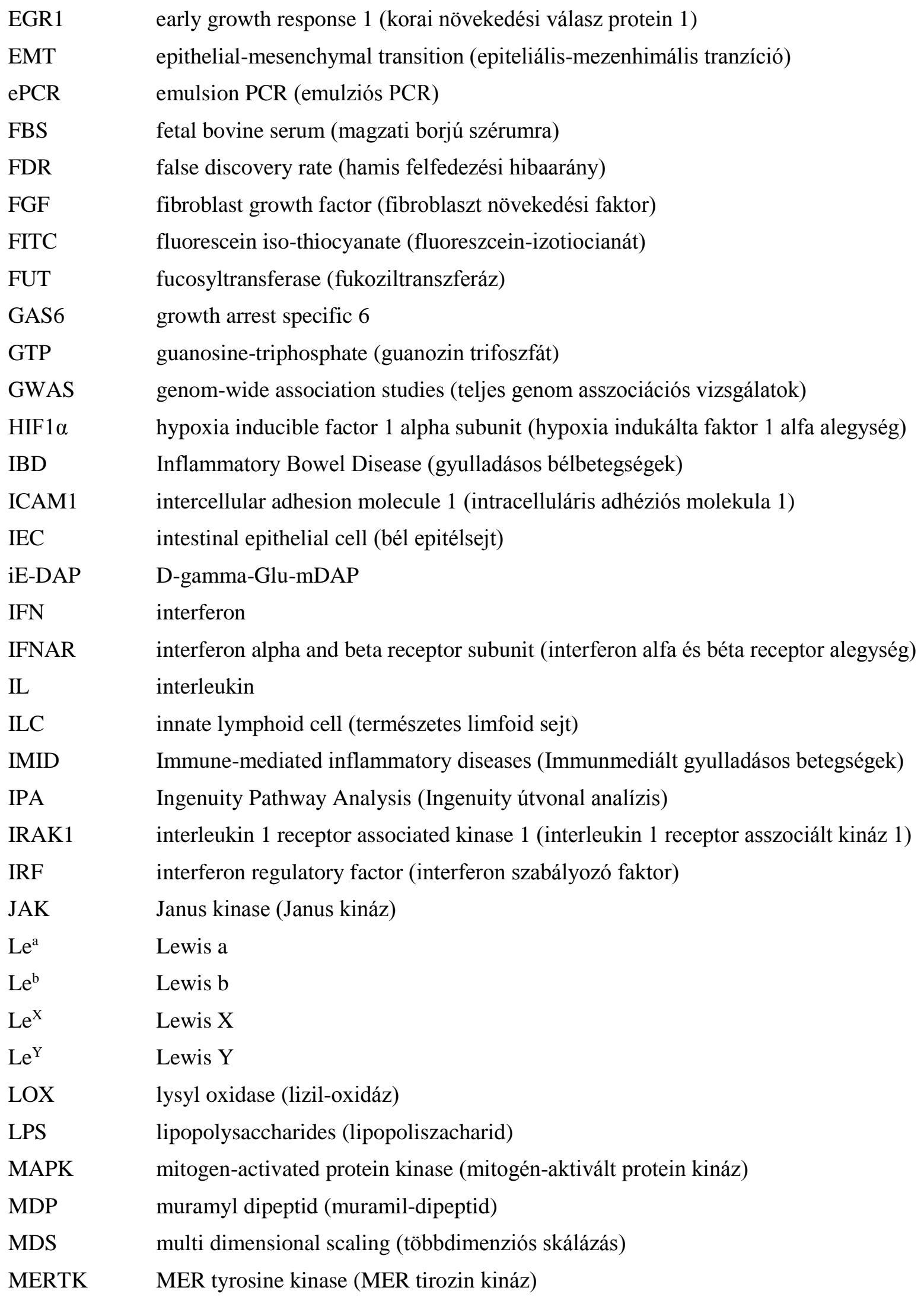




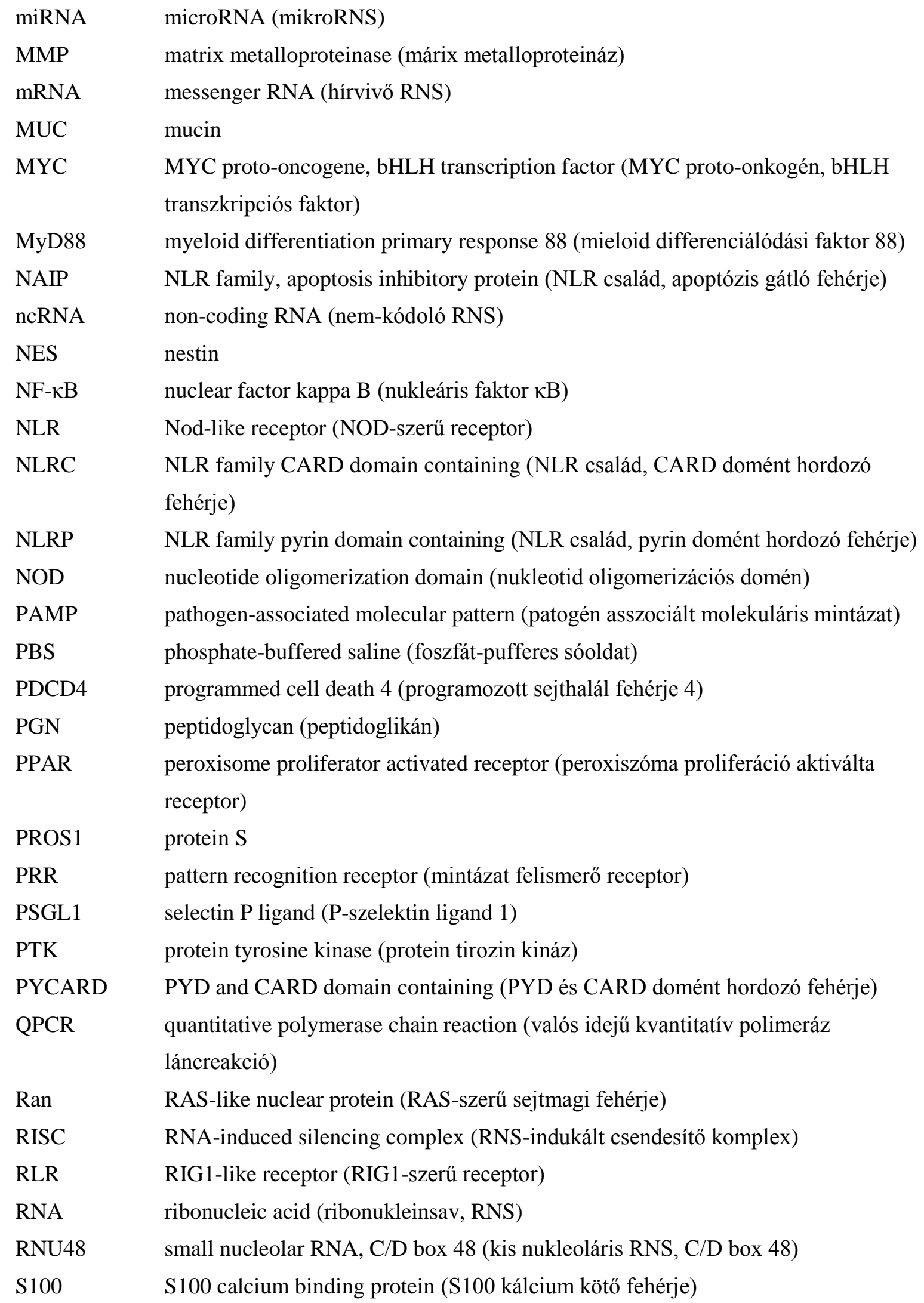




\begin{tabular}{|c|c|}
\hline $\mathrm{SD}$ & Standard deviation (szórás) \\
\hline SEM & standard error of the mean (átlag szórása) \\
\hline SHIP1 & INPP5D inositol polyphosphate-5-phosphatase D \\
\hline $\mathrm{sLe}^{\mathrm{a}}$ & szialil-Lewis a \\
\hline $\operatorname{sLe}^{\mathrm{X}}$ & szialil-Lewis $\mathrm{X}$ \\
\hline SNAI & snail family transcriptional repressor (snail család, transzkripció gátló faktor) \\
\hline SOCS & suppressor of cytokine signaling (citokin jelátvitelt szuppresszáló fehérje) \\
\hline ss & single-stranded (egyszálú) \\
\hline STAT & $\begin{array}{l}\text { signal transducer and activator of transcription (jeltovábbító és transzkripciós } \\
\text { aktivátor) }\end{array}$ \\
\hline TAM & $\begin{array}{l}\text { TYRO3-AXL-MERTK protein tyrosine kinase (TYRO3-AXL-MERTK protein } \\
\text { tirozin kináz) }\end{array}$ \\
\hline TGF $\beta$ & transforming growth factor beta 1 (transzformáló növekedési faktor- $\beta$ ) \\
\hline TIRAP & TIR domain containing adaptor protein (TIR domént hordozó adaptor fehérje) \\
\hline TLR & Toll-like receptor (Toll-szerü receptor) \\
\hline TME & tumour microenvironment (tumor mikrokörnyezet) \\
\hline TNBS & 2,4,6-trinitrobenzenesulfonic acid (2,4,6 - trinitrobenzén szulfon sav) \\
\hline TNF $\alpha$ & tumor necrosis factor alpha (tumor nekrózis faktor alfa) \\
\hline TP53 & tumor protein p53 (tumor fehérje p53) \\
\hline TRAF6 & TNF receptor associated factor 6 (TNF receptor asszociált faktor 6) \\
\hline TREM1 & triggering receptor expressed on myeloid cells 1 \\
\hline TRIF & TLR adaptor molecule 1 (TLR adaptor molekula 1) \\
\hline TWIST & twist family bHLH transcription factor (twist család bHLH transzkripciós faktor) \\
\hline TYRO3 & TYRO3 protein tyrosine kinase 3 (TYRO3 protein tirozin kináz 3) \\
\hline U6 & U6 small nuclear RNA (U6 kis nukleoláris RNS) \\
\hline $\mathrm{UC}$ & Ulcerative colitis (colitis ulcerosa) \\
\hline UTR & untranslated region (nem-transzlálódó régió) \\
\hline VHL & von Hippel-Lindau tumor suppressor (von Hippel-Lindau tumor szuppresszor) \\
\hline VIM & vimentin \\
\hline ZEB & zinc finger E-box binding homeobox (cinkujj E-box-kötő homeobox fehérje) \\
\hline
\end{tabular}




\section{IRODALMI ÁTTEKINTÉS}

\subsection{A veleszületett immunitás}

A veleszületett immunrendszer az első védelmi vonal a szervezetet érő káros behatásokkal szemben, mely a saját és nem-saját struktúrák megkülönböztetése révén gyulladás indukálásával valósul meg. Az immunválasz aktiválása és kivitelezése számos molekuláris és sejtes komponens hálózatszerü interakcióján keresztül zajlik. Együttmüködésük eredménye az akut gyulladás, mely fontos szerepet tölt be a szöveti homeosztázis fenntartásában. Összetettsége miatt azonban a szabályozás bármely szintjén bekövetkező hiba az immunválasz túlzott müködéséhez, elnyúlásához, krónikus gyulladás kialakulásához vezet/het [1].

\subsubsection{A veleszületett immunválasz aktiválása}

A veleszületett immunitás egyik elsődleges feladata a szervezetet érő káros hatások érzékelése: utóbbiakat változatos molekuláris mintázatok jellemezik, amelyeket specifikus mintázat felismerő receptorok (pattern recognition receptor, PRR) ismernek fel. Az immunválaszt aktiváló molekuláris mintázatok származhatnak akár egy patogén baktériumból (pathogen-associated molecular pattern/patogén asszociált molekuláris mintázat, PAMP) vagy a szervezet károsodása folytán létrejövő saját molekulából (dangerassociated molecular pattern/veszély asszociált molekuláris mintázat, DAMP) [2]. A sejtbeli lokalizációjuk alapján többféle PRR csoportot különböztethetünk meg: C-típusú lektinek, Toll-szerü receptorok (Toll-like receptor, TLR), RIG1-szerü receptorok (RIG1-like receptor, RLR), NOD-szerü receptorok (NOD-like receptor, NLR) és AIM-szerü receptorok (AIMlike receptor, ALR) [3].

A TLR-ek a sejtfelszínen (pl.: TLR-1, 2, 4, 5, 6 és 10), vagy az endoszómák felszínén (pl.: TLR-3, 7, 8 és 9) elhelyezkedő transzmembrán fehérjék, melyek a PAMP/DAMP felismerését követően molekuláris kaszkád beindításával gyulladáskeltő molekulák, például citokinek és kemokinek kifejeződését indukálják (1. ábra). 


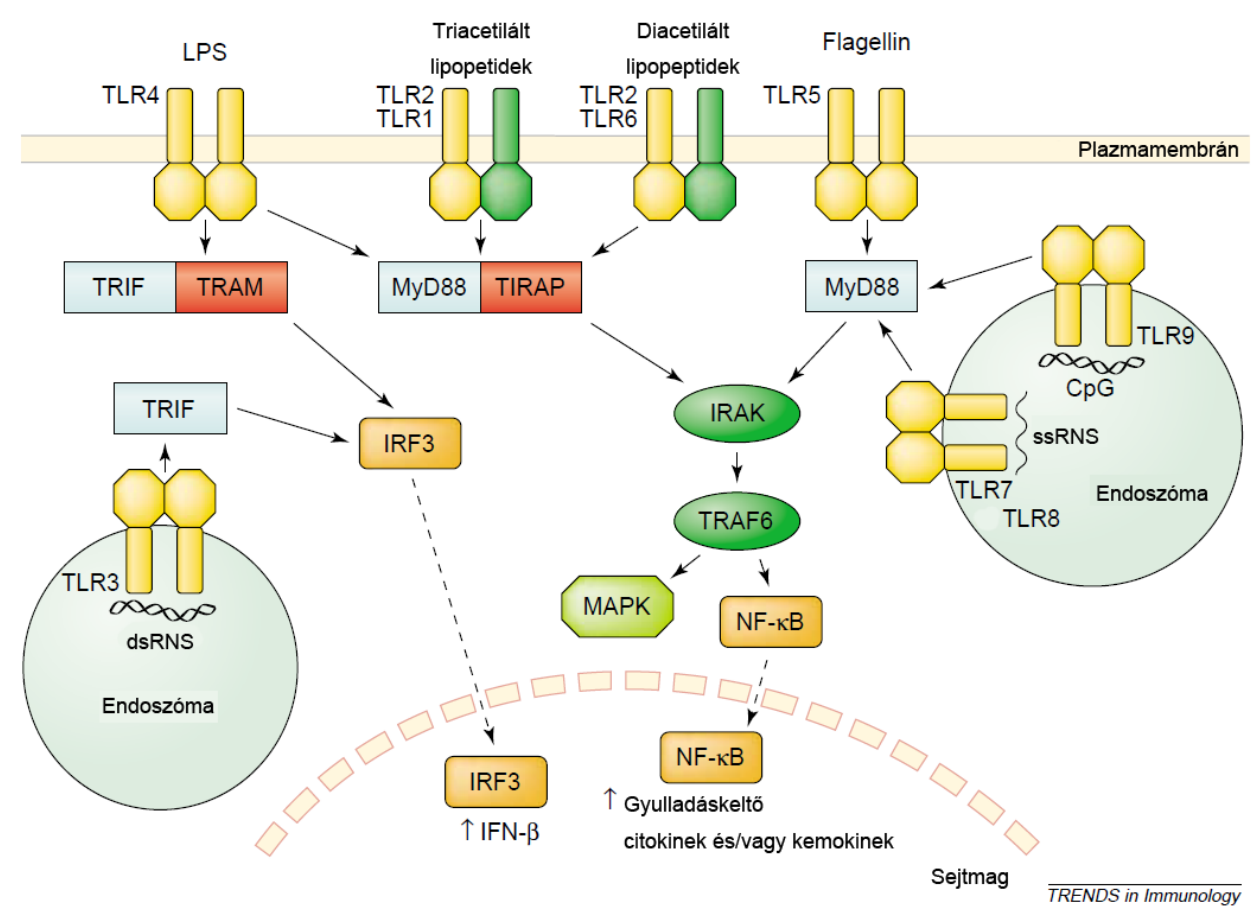

1. ábra A TLR jelátvitel áttekintése. Az extracelluláris vagy endoszómákban tárolt ligandok kötését követően a TLR receptorok jelátviteli kaszkádot indítanak be, ami gyulladáskeltő citokinek és kemokinek expresszióját eredményezi. A TLR3 kivételével, mindegyik TLR jelátvitel történhet MyD88 adaptor molekulán keresztül is. A TLR1/2/4/6 receptorok ezen kívül transzmembrán doménjük révén a TIRAP fehérjével is interakcióba léphetnek. A TLR3 a TRIF jeltovábbító molekulát aktiválja, ami a TLR4 jelátvitelben a TRAM fehérjével kapcsolódva MyD88 független útvonal aktiválást teszi lehetővé. A jelátvitel utolsó lépéseként az IRF3/7, NFkB stb. beindítják a gyulladáskeltő gének transzkripcióját ([4] alapján módosítva).

A TLR-ek által szabályozott immunválasz célja a betolakodó mikroorganizmusok elpusztítása illetve a szöveti homeosztázis helyreállítása. Jellegzetes TLR2 ligand a peptidoglikán (PGN), mely a Gram-pozitív baktériumok sejtfalalkotója; ezzel ellentétben a legtöbb Gram-negatív baktériumra jellemző lipopoliszacharid (LPS) felismerése TLR4-en keresztül történik [5] (1. ábra).

Az NLR receptorok népes családjába citoplazmatikusan elhelyezkedő PRR-ek tartoznak, melyek osztályozása hasonló NATCH doménjük és leucinban gazdag ismétlődő szekvenciáik alapján történik [6]. Változatos szubsztrát specificitással és funkcióval rendelkeznek; többek között nélkülözhetetlenek az antimikrobiális és antivirális válasz végrehajtásában (2. ábra) [7, 8]. 


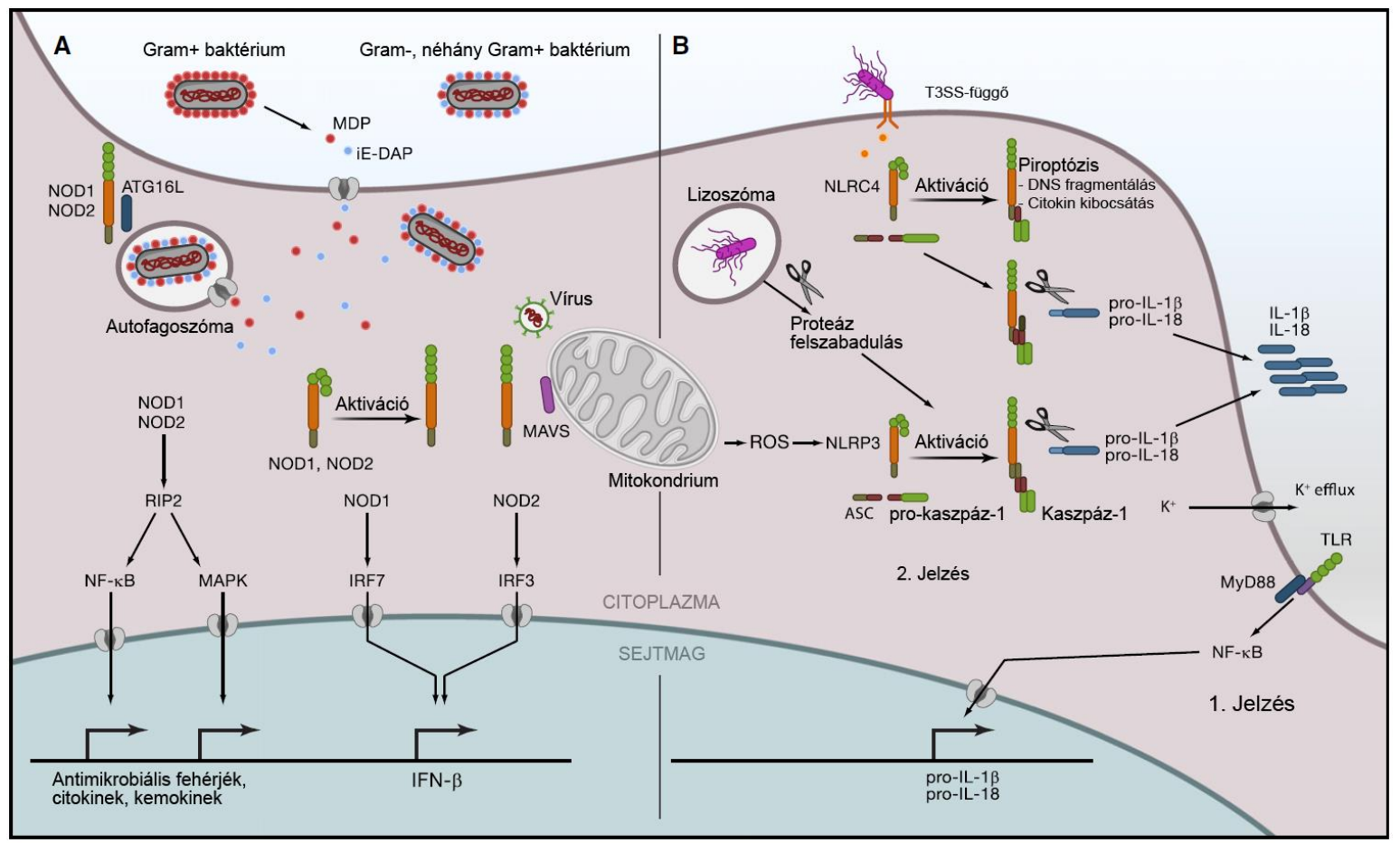

2. ábra: Az NLR receptorok mikrobiális ágensek általi aktivációja. (A) $\mathrm{Az}$ extra/intracelluláris baktériumokból vagy vezikulumokból származó MDP és iE-DAP ligandok NOD1/2 általi felismerése NFкB vagy MAPK jelátvitelt aktivál, ami antimikrobiális fehérjék és gyulladáskeltő citokinek/kemokinek expresszióját indukálja. (B) Az inflammaszóma alkotó NLR receptorok aktiválását számos exogén vagy endogén eredetü ligand kiválthatja, mely a komplex összeszerelődését eredményezi. Az inflammaszóma a prokaszpáz-1 enzimatikus hasításával funkcióképes kaszpáz-1-et hoz létre, ami a citoplazmában inaktív formában tárolt citokinek (pl.: IL1 $\beta$ ) érését segíti elö ([7] alapján módosítva).

A sejtbe bejutó PAMP-ok felismerésén kívül az NLR-ek fontos feladatot látnak el a gyulladáskeltő interleukinek (IL; pl.: IL1 $\beta$, IL18 és IL33) aktív konformációjának kialakításában inflammaszóma komplexekként [9]. Az inflammaszómát alkotó NLR-ek az NLRP3, NLRP6, NLRP12, NLRC4, NLRC5 és az NLR-szerü AIM2, a ligand kötését követően az PYCARD (vagy ASC) adaptor fehérje segítségével a citoplazmatikus prokaszpáz-1 hasítását végzik, ami végrehajtó kaszpázként a citokin prekurzorok érését segíti elő (2B. ábra) [9, 10]. Ismert ligandjaik a mikrobiális eredetű PAMP-ok mellett a saját sejtekből származó DAMP-ok, mint például az S100A8 és S100A9 [11]. Egyes NLR-ek, például az NLRP6, negatívan szabályozzák a gyulladást és hatással vannak a bél mikrobiomjának összetételére [12, 13]. Ezzel szemben mások, például a NOD2, kiemelkedően fontosak a bél homeosztázisának fenntartásában, ami a muramil dipeptid 
(MDP) felismerésén keresztül képes az NF-kB által szabályozni a gyulladás-keltő és/vagy gátló effektor molekulák kifejeződését (2A. ábra). Az NLR-ek hibás müködését összefüggésbe hozták az immunsejtek abnormális aktiválódásával, továbbá a NOD2-t kódoló genomi lókuszban létrejött mutációk hajlamosító tényezők a tápcsatorna gyulladásos és daganatos elváltozásaiban [14-16].

\subsubsection{A veleszületett immunrendszer végrehajtóinak toborzása}

A PRR-ek aktiválása számos jelátviteli utat indít be, melyek gyulladásos effektor molekulák, föként citokinek és kemokinek kifejeződését indukálják. Ezen kis molekulasúlyú, szekretált kemotaktikus fehérjék alapvető szerepe az immunválasz sejtes komponenseinek az érintett szöveti régióba való toborzása. A folyamat során megkülönböztethetünk gyulladás-keltő, másnéven proinflammatorikus és -gátló, azaz antiinflammatorikus citokineket és kemokineket. Jellegzetes gyulladás-keltő citokinek többek között a TNFa (tumor necrosis factor $\alpha$ ), az IL6 és az IL1 $\beta$; ezzel szemben gyulladás-gátló például az IL10 [17]. A proinflammatorikus kemokinek közé tartozik az CXCL8 (Chemokine (C-X-C motif) ligand; korábban IL8), melynek rágcsálókban a CXCL1 (Chemokine (C-X-C motif) ligand 1) felel meg [18].

Az immunválasz hatékony és gyors kialakítása érdekében a gyulladáskeltő TNF $\alpha$ és IL1 $\beta$ inaktív pro-TNF $\alpha$ és pro-IL1 $\beta$ formában halmozódik fel a sejtekben. Az immunválasz aktiválódását követően a de novo citokin expresszió fokozásán kívül, a pro-TNF $\alpha$ és proIL1 $\beta$ érése is megvalósul. Az NLR fehérjékből felépülő inflammaszóma komplex enzimatikus hasítás útján hozza létre az aktív IL1 $\beta$-t [9], míg a funkcióképes TNF $\alpha$ érését mátrix metalloproteinázok (MMP-k), például MMP13 segíti elő [19].

\subsubsection{A veleszületett immunválasz sejtes komponensei}

A gyulladásos válasz végrehajtói az immunsejtek, melyek a szervezet védelmére és a homeosztázis fenntartására specializálódott sejttípusok. A veleszületett immunitás sejtjei közé tartoznak a mieloid sejtek és a limfoid eredetü ILC sejtek (innate lymphoid cells, ILCs) [20]. A szerzett immunitásban szerepet játszó T- és B-sejtekhez hasonlóan, az ILC-k közös limfoid progenitor sejtből fejlödnek, azonban nem expresszálnak antigén specifikus 
receptorokat. Az egy-sejt izolálási módszerek fejlődésének köszönhetően az ILC-k további három alcsoportját írták le a különbözö sejtfelszíni markerek és eltérő génexpressziós mintázatuk alapján, aminek megfelelően az ILC szubpopulációk (ILC1, ILC2, ILC3) eltérő feladatok ellátására specializálódtak [21]. Az ILC1 sejtek az intracelluláris paraziták érzékelését követően TNF $\alpha$ és IFN $\gamma$ termelésével mieloid sejteket toboroznak, míg az ILC2 sejtek féreg fertőzés esetén IL13 révén fokozzák a simaizom kontrakciót és a goblet sejtek nyák szekrécióját. Az ILC3 típus képviselöi IL17 és IL22 termelésével a neutrofil granulociták toborzásával és antimikrobiális fehérjék kifejeződésének növelésével szállnak szembe a patogén gombákkal és extracelluláris baktériumokkal [20]. A mieloid sejtek közé tartoznak a monociták, makrofágok, dendritikus sejtek és granulociták, melyek aktiválódását a PAMP-ok és DAMP-ok széles skálája képes előidézni. Ezek a sejttípusok többek között részt vesznek a betolakodók elpusztításában, fagocitózisában, a sérült sejtekböl származó törmelékek eltakarításában, a szöveti homeosztázis helyreállításában [22].

Az immunreakció során elengedhetetlen más szövetalkotók, többek között a vérerek belső falát alkotó endotél sejtek és a felszíneket borító epitélsejtek közremüködése is. A szöveti homeosztázis felborulása során aktiválódott, gyulladt endoltél sejtek az immunsejtek véráramból való kihorgonyzására alkalmas molekulákat expresszálnak a felszínükön és nő a vérerek áteresztőképessége. Az endotél sejtek és leukociták adhézios molekulákat (szelektinek, integrinek) és kemokin receptorokat expresszálnak, melyekhez mint kihorgonyzó struktúrához kapcsolódnak ligandjaik (szelektin ligandok pl.: PSGL1; immunoglobulinok pl.: ICAM1; és kemokinek pl.: CCL2) [23]. A szelektinek és ligandjaik közötti kapcsolat kialakításában nélkülözhetetlenek a ligandok szénhidrát egységei. A funkcióképes szelektin ligandok és más glikoproteinekre jellemző szénhidrát antigének kialakításáért többek között a fukoziltranszferázok (FUT) a felelősek. Leukocitákban például az a1,3/4-FUT alcsaládba tartozó FUT4, FUT7 és FUT9 végzik a Lewis antigének közül a sLe $^{\mathrm{x}}$ antigén szintézisét $[24,25]$. Emellett még a Lewis antigének közé tartoznak a Lewis$\mathrm{X} /-\mathrm{Y} /-\mathrm{a} /-\mathrm{b}\left(\mathrm{Le}^{\mathrm{X}}, \mathrm{Le}^{\mathrm{Y}}, \mathrm{Le}^{\mathrm{a}}, \mathrm{Le}^{\mathrm{b}}\right)$ és az ún. szialil-Lewis-X/a tetraszacharid antigének ( $\mathrm{sL}^{\mathrm{x}}$, $\mathrm{sLe}^{\mathrm{a}}$ ) is [24]. A létrejövő adhéziós molekula/ligand interakció segíti elő az agranulociták (pl.: monociták) és granulociták (pl.: neutrofil granulociták) aktiválását és infiltrációját a gyulladt szöveti állományba [26]. 
A veleszületett immunválasz sejtes komponensei közül kulcsfontosságúak az epitélsejtek is, melyek a közöttük kialakuló sejt-sejt kapcsolatok révén egy szorosan záródó védőréteget, egy elhatároló struktúrát, az epitéliumot alakítják ki. Szöveti elhelyezkedésüknek megfelelően képesek további funkciók ellátására is adaptálódni. Speciális felszíni struktúrák kialakításával például növelhetik a felszínt, mely hatékonyabb felszívódást tesz lehetővé a tápcsatornában, de ezen kívül szekrécióra képes sejttípussá is differenciálódhatnak. A sejteket összekötő horgonyzó struktúrák összekapcsolják a sejtek citoszkeletonját és az extracelluláris mátrix alkotóhoz is csatlakoznak, ezzel segítik az epitél sejtekre jellemző apikális-bazális polaritás kialakítását. Ennek köszönhetően az epitélium egy szigorúan szabályozott kommunikációs csatornának is tekinthetö a külvilág és a belső, szöveti környezet között. Az epitélsejtek a veszély jel érzékelése révén, vagy sérülésük következtében maguk is képesek gyulladáskeltő fehérjéket szekretálni, amivel aktiválhatják az immunválaszt [27].

\subsubsection{A veleszületett immunválasz szabályozása}

Negatív regulátorok: a TAM receptorok

A TAM receptor család tagjai a TYRO3, az AXL és a MERTK, sejtfelszíni receptorok, melyek konzervált KWIAIES szekvencia motívumuk alapján külön családba sorolhatóak a protein-tirozin-kinázok (PTK) csoportján belül [28]. Ligandjaik a Growth arrest-specific (GAS6) és a Protein S (PROS1), melyek kötődésükkel a receptorok dimerizációját ezáltal aktivációját idézik elő. A TAM receptoroknak és ligandjaiknak fontos szerepe van az apoptótikus sejtek fagocitózisában, ezen kívül az immun-, ideg- és reproduktív-rendszer megfelelő müködésében nélkülözhetetlen szignalizációs útvonalakat aktiválnak (3. ábra). Ismert továbbá, hogy a TAM receptorok dendritikus sejtekben és makrofágokban a TLR-indukált gyulladásos válasz inhibítorai. A gátlás az I. típusú IFN receptor (IFNAR) aktiválásával, SOCS1 és SOCS3 (Suppressor of cytokine signaling-1, -3) molekulákon keresztül valósul meg [29, 30]. A TYRO3 gyulladás gátló hatása allergiás reakciókban és a paraziták elleni 2-es típusú immunválaszban is igazolt [31]. 


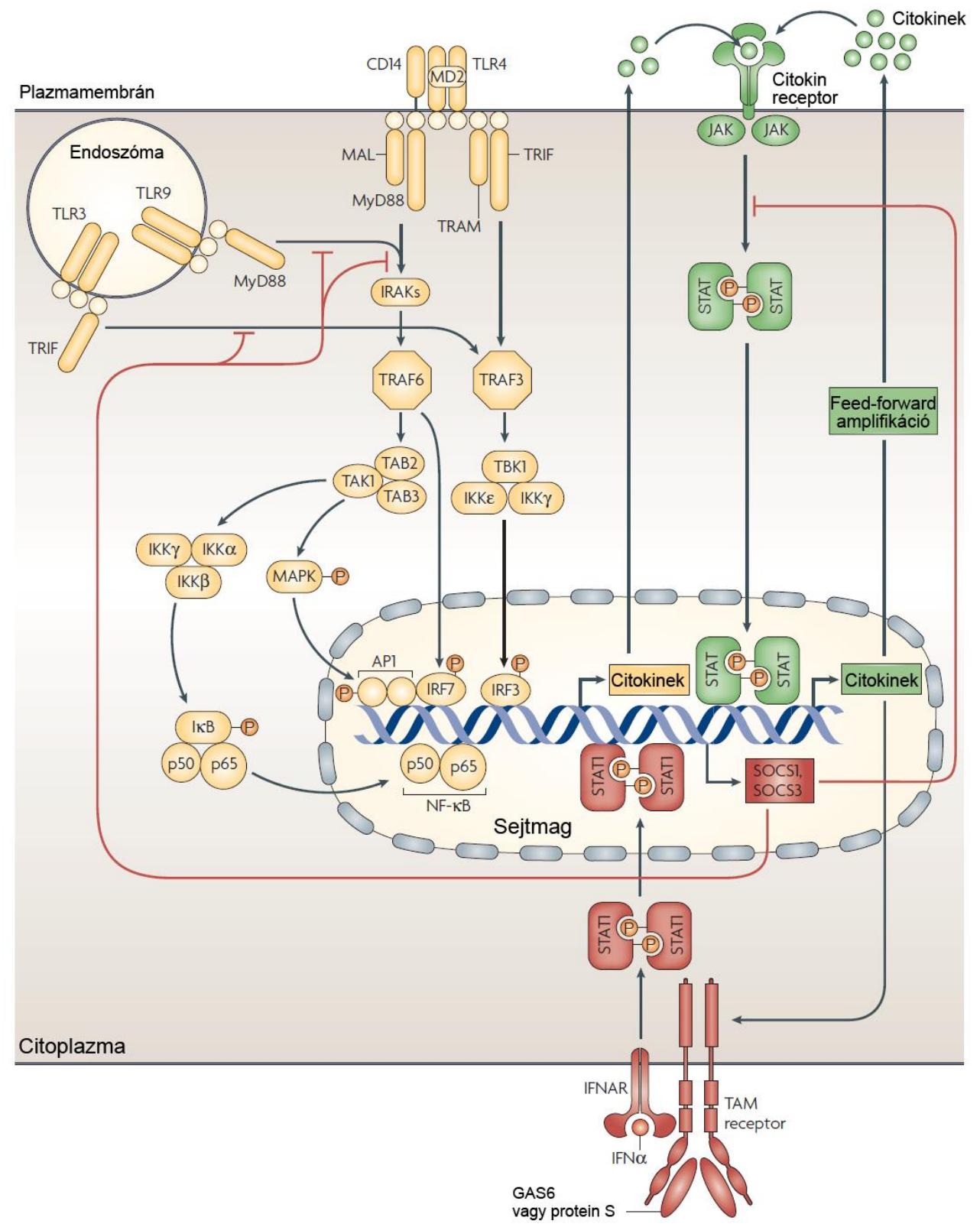

3. ábra: A TAM receptorok szerepe a gyulladásos folyamatok szabályozásában. A TLR és citokin receptorok aktiválódása a TAM receptorok expresszióját indukálja, melyek STAT1 jeltovábbító molekula segítségével - többek között - a gyulladás-gátló SOCS1 és SOCS3 transzkripcióját idézik elő. A SOCS fehérjék a TLR és citokin jelátviteli kaszkádban szerepet játszó molekulák degradációja által csökkentik a gyulladásos választ ([32] alapján módosítva).

A TAM receptorok funkciójának vizsgálatára használt in vivo egér knock-out rendszerekben az autoimmun betegségekre jellemző tüneteket figyelték meg mint például a perifériás limfoid szervek, a lép, a nyirokcsomók és az ízületek duzzanatát, valamint a 
dendritikus sejtek és makrofágok fokozott proinflammatorikus citokin termelését [32]. Ezen kívül a TAM jelátvitelben fontos molekulákat kódoló génekben bekövetkező mutációkat kapcsolatba hozták több autoimmun betegséggel is, mint például a reumatoid artritisz és a szisztémás lupus erythematosusz, melyekre szintén krónikus gyulladás jellemző [33].

\section{Mátrix metalloproteinázok}

A mátrix metalloproteinázok, mint azt nevük is tükrözi, az extracelluláris mátrix (ECM) dinamikus formálásban, az ECM alkotóinak lebontásában vesznek részt, ezen kívül a citoplazmában inaktív formában tárolt citokinek és kemokinek enzimatikus hasítását végzik. Emlősökben 24 metalloproteináz tartozik az MMP családba: léteznek membránkötött (pl.: MMP-14, -15, -16, -17, -23, -24, -25) és szekretált (pl: MMP-1, -2, -3, -7, -8, -9, -10, 11, -12, -13, -20, -21 -26, -28 ) MMP-k, míg további csoportosításuk domain szerkezetük és szubsztrát specifitásuk alapján történik. Az MMP-k részt vesznek többek között az ECM alkotó és sejt-sejt kapcsolatok kialakításáért felelős fehérjék, például a kollagének, az Ecadherin és fibrin bontásában. Ismert szubsztrátjaik még a CCL2, -7, -8, -13, a CXCL1, a CXCL11 kemokinek valamint az IL1 $\beta$ és TNF $\alpha$ citokinek $[34,35]$.

\subsubsection{A tápcsatorna immunrendszere}

Az emésztőszervrendszer feladata a táplálék felvétele, emésztése és a tápanyagok felszívódásának lebonyolítása. Mindeközben számos mikroorganizmus, köztük baktériumok, vírusok és gombák is bekerülnek a bélbe, melyek egy része a szervezet számára értékes funkciókat ellátó közösséget formál, a bél mikrobiótáját. A mikrobióta vagy más néven normál flóra alkotói a szervezet számára hasznos, kommenzalista mikroorganizmusok, melyek segítik a káros, patogén baktériumok féken tartását. A tápcsatornát bélelő epitélsejtek (intestinal epithelial cells, IECs) fizikai illetve kémiai barrierek létrehozásával hozzájárulnak a mikrobiom és a gazda szervezet közötti szimbiotikus egyensúly fenntartásához. Ezek a sejtek a nyálkahártya alkotóiként egyrészt fizikai határt szabnak a betolakodókkal szemben, másrészt a mikrobiom összetételétől függően citokineket és kemokineket szekretálva tartják a kapcsolatot az immunrendszerrel [36]. 
Fizikai határt jelentenek a szoros sejt-sejt kapcsolatok, az abszorbtív sejtek mikrovillusait borító glikokalix, továbbá a goblet sejtek által termelt viszkózus réteget alkotó glikoproteinekben gazdag „,mucus-nyák” réteg [37]. A vékonybélhez képest a vastagbélben nagyságrendekkel több mikroorganizmus kolonizál, továbbá a goblet sejtek száma is sokkal magasabb, ami lehetővé teszi egy sürübb belső és egy lazább külső rétegből felépülő bevonat létrehozását a vastagbél felszínén (4. ábra). A gél-formáló mucin 2 (MUC2) erősen Oglikolizált fehérje, polimerizációja révén kialakítja a tömör belső réteget, ami a külsővel ellentétben mikroorganizmusoktól mentes és távol tartja a bél lumenében élő kommenzalistákat és patogéneket a nyálkahártyától [38].

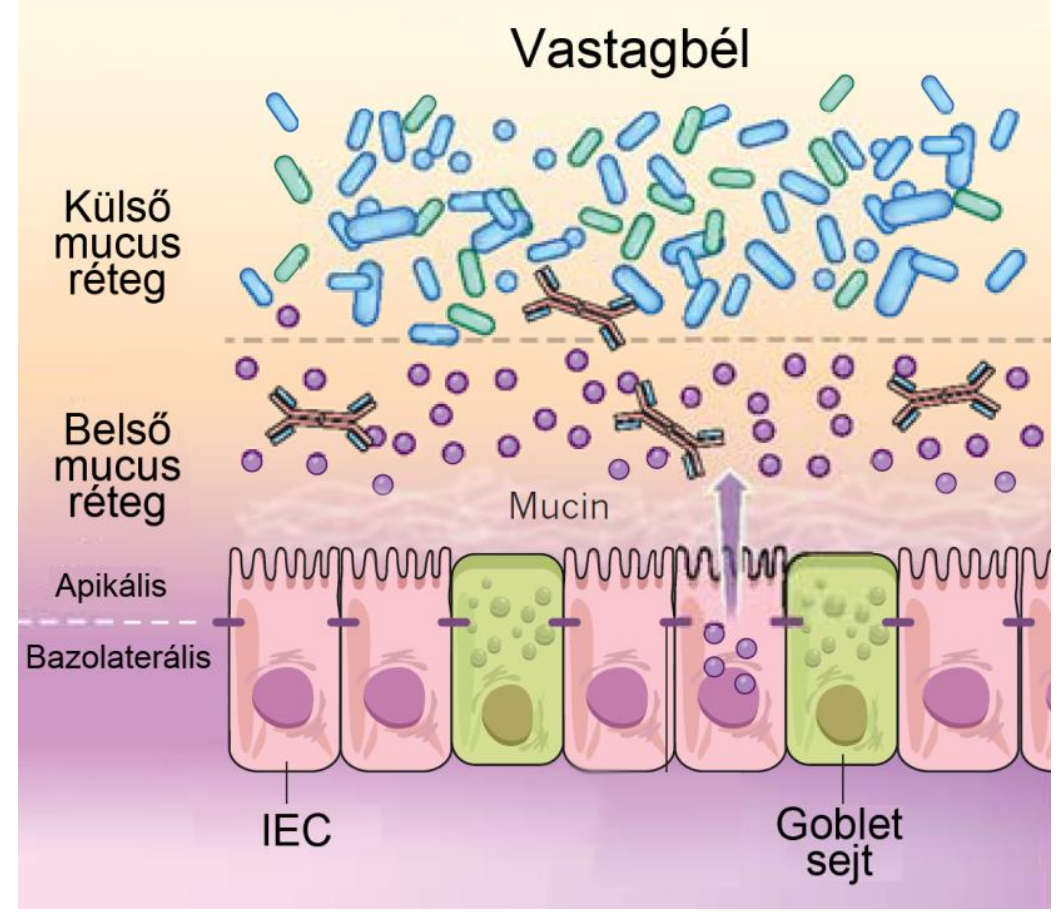

4. ábra: A vastagbél epitélium barrier szerepe. Az epitélium kialakításában résztvevő különböző IEC alpopulációk a sejtek között létrejövő szoros kapcsolatok által egy folytonos, apikális-bazális polaritású sejtréteget hoznak létre. Az abszorptív sejtek a tápanyagok felvétele mellett, a mikrobióta összetételére reagálva antimikrobiális fehérjéket szekretálnak. A goblet sejtek által kiválasztott mucin alakítja ki a keresztkötésekben gazdag proteoglikán gél réteget az IEC-k felszínén, melynek belső sürübb polimer rétege távol tartja a mikroorganizmusokat, míg a lazább külső réteg átjárható a mikrobiom számára ([39] alapján módosítva).

A mucinok két fö csoportja a membrán kötött, apikális felszínhez horgonyzott és a szekretált/gél-formáló típusok, melyeket nagymértékű glikolizáltság jellemez. A vastagbél 
krónikus gyulladásával járó colitis ulcerosaban szenvedők esetén, például a MUC2 glikolizációjának változását figyelték meg: az összetettebb glikán származékok helyett a rövidebb láncok voltak jellemzőek, ami fokozott gyulladással társult a vastagbélben [40].

A sejtek felszíni tulajdonságait meghatározó és a nyálkahártya védelmét biztosító glikokalix kialakítása a glikoziltranszferázok, köztük fukoziltranszferázok bonyolult együttmüködésének az eredménye [37]. A IEC sejtek által expresszált fukoziltranszferáz 2 (Fut2) a gazda-kommenzalista közötti szimbiózis fenntartása érdekében részt vesz a fizikai barrier kialakításában [41]. Ezen kívül a Fut2 kulcsfontosságú a bakteriális virulenciáért felelős gének kifejeződésének szabályozásában is, azáltal hogy az általa fukozilált, a bél lumenébe szekretált fehérjék fukóz egységeinek emésztése során megváltoztatja az ott kolonizáló baktériumok metabolikus folyamatait, így csökkentve a virulenciát [42]. Az IEC sejtek Fut2 termelését az ILC3 sejtek által expresszált IL22 idézi elö, amit a kommenzalista baktériumok indukálnak. Ismert továbbá, hogy egér modellben a Fut2 hiánya növeli a patogének által kiváltott gyulladást a tápcsatornában [41].

A szövetek védelmére az IEC-k által termelt antimikrobiális peptidek kémiai barriert képeznek - amik főként a vékonybélben fejeződnek ki - ezen kívül a mintázat felismerő receptoraik és az általuk szekretált citokinek riadóztatják az immunsejteket és immunreakciót váltanak ki a betolakodók elpusztítása céljából.

A fizikai és kémiai barrierek mellett elengedhetetlen, hogy a szervezet számára hasznos mikroorganizmusokkal szemben tolerancia alakuljon ki. A tolerancia egy aktív folyamat, ami megakadályozza, hogy immunválasz induljon a kommenzalistákkal szemben, így azok a tápanyagokért való versengés során visszaszorítják a patogén mikroorganizmusokat [39]. A normál flóra a veleszületett immunitással együttmüködve hozzájárul a homeosztázis fenntartásához és a sebgyógyulás elősegítéséhez, így többek között védelmet nyújt a vastagbélgyulladás kialakulása ellen [41].

A veleszületett immunrendszer müködésében fontos géneket érintő mutációk felborítják ezt az egyensúlyt, hatással vannak az epitélsejtek képződésére és a nyálkahártya regenerálódására, ami növeli a krónikus gyulladás kialakulását és a karcinogenezist a bélben. 
A gyulladás negatív regulátorainak mutációjával csökken vagy megszünik a tolerancia a kommenzalista mikrobiommal szemben, ami felerősíti a gyulladásos választ [43].

\subsection{Immunmediált gyulladásos betegségek}

Az immunmediált gyulladásos betegségek (Immune-mediated inflammatory diseases, IMIDs) csoportjába olyan defektusok tartoznak, melyek közös jellemzője a szervezet valamely szövetét érintő, vagy akár a teljes szervrendszerre kiterjedő krónikus gyulladás. Ide sorolható többek között a pikkelysömör (psoriasis), a reumatoid artritisz és a gyulladásos bélbetegségek (Inflammatory Bowel Disease; IBD). Habár különböző szervrendszereket érintő krónikus gyulladás jellemzi őket (bőr, ízületek, tápcsatorna), patomechanizmusuk hátterében azonos, a gyulladás szabályozásában fontos jelátviteli útvonalak hibás müködése és/vagy a gyulladásos citokinek egyensúlyának felborulása áll. Kezelésükre újabban a leggyakrabban TNF $\alpha$ gátló készítményeket használnak, de az IMID betegségek multifaktoriális jellegéből adódóan, a betegek csak bizonyos hányadánál értek el javulást ezzel a terápiával [44]. Az IMID csoportba sorolt betegségek előfordulása föként a nyugati társadalmakra jellemző, ahol a populáció 5-7 \% érintett [45].

\subsection{A gyulladásos bélbetegségek - IBD}

A gyulladásos bélbetegségek (Inflammatory Bowel Disease; IBD) két fô típusa a Crohn-betegség (Crohn-disease; CD) és a colitis ulcerosa (ulcerative colitis; UC). Közös jellemzőjük a krónikus gyulladás, mely $\mathrm{CD}$ esetén a szájüregtől a végbélnyílásig a tápcsatorna bármely szakaszán, míg colitis ulcerosaban szenvedő betegeknél föként a vastagbélben kialakuló léziók, fekélyek megjelenésével jár. Az IBD élethosszig tartó betegség, mely során aktív és remissziós periódusok követik egymást. Föbb tünetei: az időszakosan visszatérő hasi fájdalom, a hasmenés, véres széklet, valamint az ezek következtében fellépő felszívódási zavarok, melyek vérszegénységhez, fáradtsághoz, súlyvesztéshez vezetnek. UC esetén a gyulladás a mukózát és szubmukózát, CD esetén mélyebb szöveti rétegeket is érinthet; jellemzö, hogy a gyulladt szakaszokat látszólag érintetlen, nem-gyulladt területek váltják [46]. Habár némely jellegzetesség alapján általában elkülöníthető a két betegség típus, azonban jelentős átfedés tapasztalható klinikai, kórtani 
megjelenésükben, tüneteikben, valamint genetikai hátterükben. A teljes genom asszociációs vizsgálatok (genom-wide association studies; GWAS) segítségével már több mint 160 IBDre hajlamosító lókuszt azonosítottak, melyek jelentős része azonos CD-ben és UC-ben [47]. A genetikai faktorok mellett, fontos szerepe van a környezeti, immunológiai és mikrobiális tényezőknek, melyek komplex interakciója idézi elő a heterogén tünetekkel megnyilvánuló gyulladásos bélbetegségek kialakulását [48].

Az IBD elöfordulásának gyakorisága világszerte folyamatos növekedést mutat, a legmagasabb előfordulási arány az észak-európai és észak-amerikai országokban élőkre jellemző [49]. Hazai tanulmányok szerint, a magyarországi lakosság esetén is folyamatos emelkedés tapasztalható az IBD-s betegek számában [50, 51]. Habár a halálozási ráta IBD-s betegeknél nem tér el nagy mértékben a normál populációtól, a vastag- és végbélrák kockázatát jelentősen növeli az IBD-re jellemző krónikus, elhúzódó gyulladás és az immunszuppresszív készítményekkel történő kezelés [52].

\subsection{A gyulladásos bélbetegségek és a vastagbélrák kialakulása közötti összefüggés}

Napjainkban a keringési rendszert érintő megbetegedések mellett, a rosszindulatú daganatok jelentik messze a leggyakoribb halálokot. A legtöbb daganat három fơbb csoportba sorolható a kiindulási sejttípus alapján. Az epitélsejt eredetü karcinómák, a tumoros elváltozások 90 \%-áért felelősek, ezzel ellentétben a kötőszöveti eredetủ szarkómák ritkán fordulnak elő. A harmadik csoporthoz tartoznak a limfómák, amelyek a vér sejtes alkotóinak, elsősorban az immunsejteknek a rosszindulatú megbetegedése.

A tumorgenezis egy összetett folyamat, mely legtöbbször egyetlen osztódó sejtből indul, ami elkerüli a differenciálódást végül sejthalált és kialakít egy sejttömeget, melyben a daganatsejtek egyre több mutációt halmoznak fel. A daganat a bazális lamina átlépését követően megtámadja a környező szöveteket, fokozott tápanyagszükséglete miatt új vérerek kialakulását indukálja, ez pedig elősegíti a szervezet távolabbi pontjaiba való áttétképzést, a metasztázist. A tumor mikrokörnyezetének (tumour microenvironment, TME) kialakítása a daganatképződés elengedhetetlen feltétele, mely effektor molekulák (citokinek, kemokinek, transzkripciós faktorok) és sejtes komponensek együttmüködésével valósul meg [53]. 
A daganatok kialakulásának csupán $10 \%$-át okozzák csíravonalban megjelenő mutációk, a fennmaradó nagyobb hányadot olyan szomatikus mutációk idézik elö, melyek környezeti tényezők hatására alakulnak ki. Sok esetben krónikus fertőzés, UV sugárzás, elhízás, szélsőséges étkezési szokások, belélegzett szennyezö anyagok, dohányzás vagy autoimmun folyamatok állnak a karcinogenezis hátterében. Ezen faktorok közös vonása, hogy krónikus gyulladást idéznek elö, és ez az abnormális védekező mechanizmus felborítja a szöveti homeosztázist [54]. Az első megfigyelés, ami a krónikus gyulladás és a tumorgenezis közötti kapcsolatot írja le, Rudolf Virchow nevéhez füződik, aki 1863-ban az immunsejtek fokozott infiltrációját figyelte meg a tumor mikrokörnyezetében [55]. Az 1990es években számos tanulmány igazolta a gyulladásban kulcsfontosságú immunsejtek, citokinek, kemokinek és növekedési faktorok jelentőségét a rákos elváltozások kialakulásában [56].

Nem minden krónikus gyulladással járó kórkép vezet tumorgenezishez, fontos az érintett szövet típusa. Míg a vastagbél és a máj hosszantartó gyulladása jelentősen növeli a rák kockázatot, addig az ízületi és izomszöveti gyulladás ritkán vezet daganatos elváltozáshoz. Másrészt maga a tumor is előidézi a gyulladást az iniciációs fázisban, a nem megfelelő vérellátás miatt nekrózissal elpusztuló sejtekből felszabaduló DAMP-ok által, ami tovább fokozza a daganatképződést azáltal, hogy a sérült szövetek helyreállítása során kialakítja a megfelelö mikrokörnyezetet és fokozza az angiogenezist [57]. A TME kialakításában résztvevő sejtes komponensek elsősorban az immunsejtek, köztük tumor asszociált makrofágok, DC-k, mieloid-eredetủ sejtek, továbbá elengedhetetlenek a fibroblasztok és az endotélsejtek is [58].

A gyulladt szövetben felhalmozódó immunsejtek citokineket és kemokineket szekretálnak, melyek az NF-אB transzkripciós faktor aktiválása révén számos jelátviteli utat

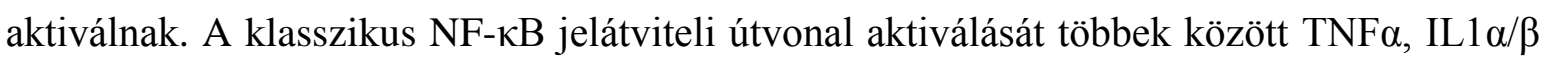
és TLR ligandok idézik elő és ezáltal a gyulladásban, sejtosztódásban, epiteliálismezenhimális tranzícióban, angiogenezisben és metasztázisban szerepet játszó gének expresszálást indukálják [58]. 
Az immunválasz a daganat fejlődésének minden stádiumában, így a primer tumor iniciációjában, az invázióban és a metasztázisban is jelentős szereppel bír. Klinikai szempontból a legkritikusabb aspektus, a bazális membrán áttörésére képes invazív tumor kialakulása, melyben az epiteliális-mezenhimális tranzíció kulcsfontosságú lépés [57].

\subsubsection{Az epiteliális-mezenhimális tranzíció}

Az epiteliális-mezenhimális tranzíció (epithelial-mesenchymal transition, EMT) során az epitélsejtek elveszítik apikális-bazális polaritásukat, fellazulnak közöttük a sejt-sejt kapcsolatok és epiteliális markerek helyett, mezenhimális markereket kezdenek expresszálni. A sejtek mozgékonnyá válnak, mátrix metalloproteinázok termelése által lebontják az extracelluláris mátrix alkotóit és invazív mezenhimális sejtekké alakulnak, melyek ellenállóak az öregedéssel és apoptózissal szemben. A folyamat ellenkező irányba is végbemehet, amit mezenhimális-epiteliális tranzíciónak nevezünk, és végeredményeként visszaáll az epiteliális fenotípus. Az EMT fiziológiás körülmények között elengedhetetlen az embriogenezisben és a szövetregenerációban, de jelentős szerepe van a daganatos elváltozások kialakulásában, a metasztázis képzésben [59].

Az EMT során a sejt-sejt kapcsolatok fellazulása a claudin és occludin kifejeződésének csökkenésével, továbbá a plazmamembránban található E-cadherin (epithelial cadherin / cadherin1, CDH1) lebontásával valósul meg [59]. Az epiteliális markerek kifejeződésének csökkenése és a mezenhimális markerek fokozott expresszálása, a SNAI (snail family transcriptional repressor, SNAI1/2), a TWIST (twist family bHLH transcription factor 1, TWIST1) és a ZEB (zinc finger E-box binding homeobox, ZEB1/2) transzkripciós faktorok által szabályozott [59]. Az EMT során a mezenhimális marker MMP9 az ECM újrarendezésével növeli a sejtek motilitását [59].

Az EMT-ben számos jelátviteli útvonal érintett, melyek a gyulladásos válasz szabályozásában is fontosak. Ilyenek a JAK-STAT és NOTCH útvonalak, a TGF $\beta$ által indukált MAPK kaszkád és a tirozin kináz receptorokon (receptor tyrosin kinase, RTK) keresztül szabályozott növekedési faktorok [59]. Az FGF-ek (fibroblast growth factor) mezenhimális irányba tolják a tranzíciót, a dezmoszómákat destabilizálják és fokozzák az integrinek és az MMP13 kifejeződését [59]. Míg az EGR1 (early growth respons 1) a SNAI 
promoterét aktiválva segíti az átmenetet, addig a jellemzően hipoxiás gyulladt szövetekben kifejeződő HIF1 $\alpha$, a TWIST aktiválása által idézi elő az EMT-t [59].

A korábban bemutatott TAM receptorok gyulladás gátló hatásuk mellett, jelentős szerepet töltenek be a daganatos elváltozások kialakulásában. Közülük az AXL fokozott kifejeződését írták le több daganat típusban is, mint például tüdő, mell, fej, nyak és vastagbél rákban is [28]. Továbbá, az AXL kifejeződésének szintje fordítottan korrelál az élettartammal és emelkedett szintje a rossz klinikai kimenetel elörejelzöje lehet daganatos megbetegedések, például mellrák esetén [60,61]. Az AXL megnevezés, a görög eredetü „anexelekto” szóból származik, ami kontrollálatlant jelent [62]. Az AXL által szabályozott jelátviteli útvonalak, mint az NF-kB és a JAK-STAT, befolyásolhatják az immunválaszt, gátolják a gyulladást és az antivirális reakciót. Másrészt az AXL fontos szerepet tölt be a tumor fejlődésben: a SNAI1/2, ZEB2 vagy TWIST transzkripciós faktorok aktiválásán keresztül epiteliális-mezenhimális tranzíciót indukál és az MMP9 által fokozza a sejtek motilitását és invázióját [63, 64]. A gyulladt szövetekre és a tumor mikrokörnyezetére jellemző limitált oxigén ellátás emelkedett HIF $1 \alpha$ termelődéshez vezet, ami nemcsak a NOTCH jelátviteli úton át, hanem az AXL szabályozásán keresztül is előidézheti az EMT-t [65-67] 


\subsection{A mikroRNS-ek szabályozó szerepe}

A tumoros elváltozások molekuláris hátterének kutatásában az elmúlt két évtizedben jelentős figyelmet kaptak a nem-kódoló RNS-ek csoportjába tartozó mikroRNS-ek (miRNS), melyek megváltozott kifejezödését írták le számos daganatféleség, többek között vastagbélrák esetén is [68]. A miRNS-ek olyan nem-kódoló RNS-ek, amelyek közvetlen funkciója a mRNS-ek poszttranszkripcionális szabályozása, ezáltal közvetett szerepük van a sejtek differenciálódásában, osztódásában és fennmaradásában [69].

\subsubsection{A miRNS-ek biogenezise}

A miRNS-ek olyan 21-23 nukleotid (nt) hosszúságú, evolúciósan konzervált molekulák, melyek vagy saját génről vagy egy fehérjét kódoló gén introni régiójából íródnak át. Az elsődleges transzkriptum, a pri-miRNS (primary-miRNA) néhány ezer nukleotid hosszú és jellemzőek rá a hajtü-szerủ másodlagos struktúrák. A pri-miRNS kifejeződése, az mRNS-ekéhez hasonlóan sok szinten szabályozott, többek között transzkripciós faktorok és kromatin módosítások által. A pri-miRNS-eket a sejtmagban egy fehérje komplex, a másodlagos struktúrák határán található egyes és kettős szálú RNS régióknál hasítja, ezzel létrehozva a pre-miRNS-eket. A komplex föbb alkotói az RNáz III típusú DROSHA, amely az RNS hasítását végzi, míg a DGCR8 felelős az ssDNS-dsDNS (single-stranded DNAdouble-stranded DNA) határ felismeréséért. A pre-miRNS 70-100 nt hosszúságú hajtü-szerü struktúra, melynek dsRNS részét alkotó szálai között nem tökéletes a komplementaritás. A pre-miRNS-ek a sejtmagból a citoplazmába a Ran-GTP-függő exportin 5 segítségével kerülnek, ahol egy újabb RNáz III típusú enzim, a DICER lehasítja róla a loop régiót, így létrehozva a 21-23 nt hosszúságú miRNS-miRNS duplexet. A duplexet a RISC komplex (RNA-induced silencing complex) veszi fel és az AGO2 segítségével széttekeri a két szálat, melyek közül a vezető szál (guide) a RISC-ben marad, a passanger szál pedig a citoplazmában degradálódik. Az érett miRNS-t tartalmazó RISC ezután az mRNS-ek 3' UTR (untranslated region) régiójában hibridizál a miRNS komplementer szekvenciájához (5. ábra). Amennyiben tökéletes az illeszkedés, a komplex kettévágja az mRNS-t, ami RNázok által lebomlik. Ha nem teljes a komplementaritás az mRNS deadenilálása előzi meg a degradációt, vagy a transzláció gátlásán keresztül valósul meg a poszt-transzkripcionális gátlás [70,71]. 


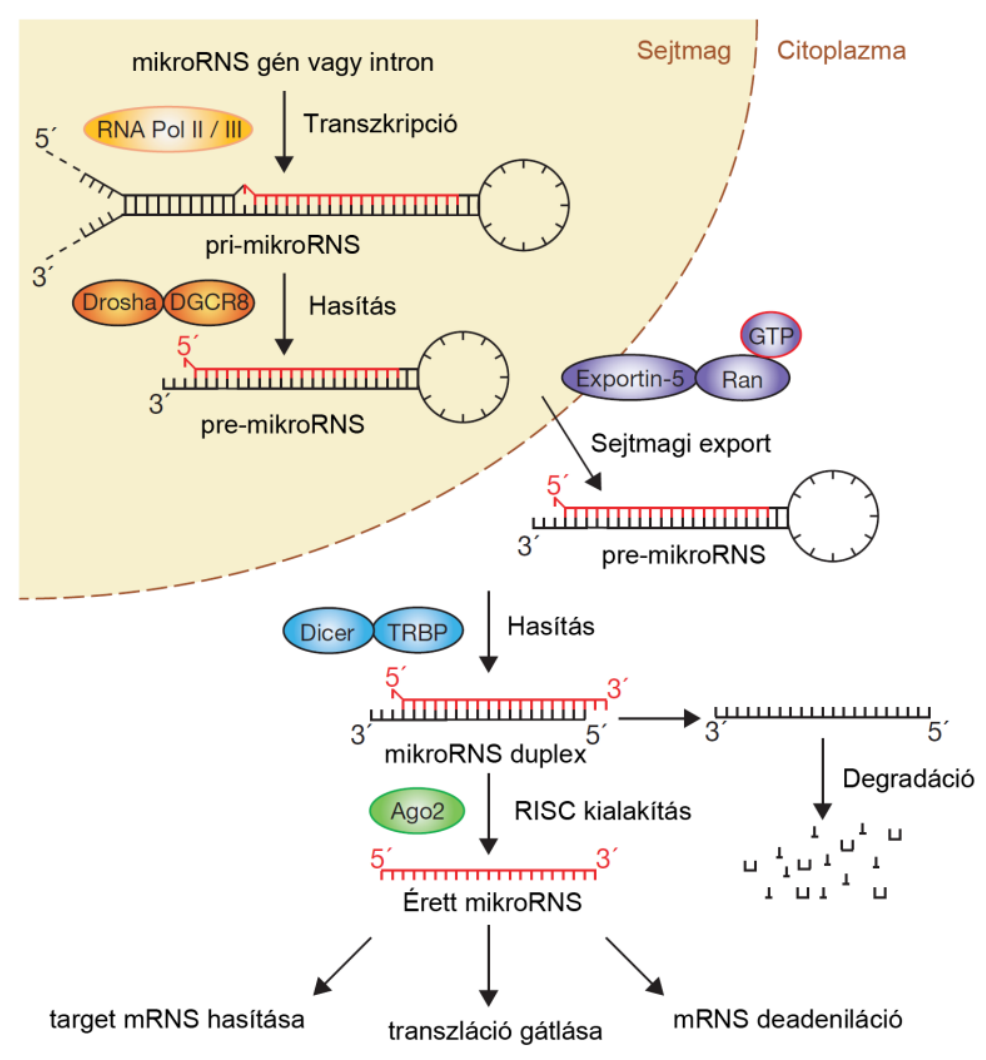

5. ábra: A mikroRNS-ek biogenezise. A sejtmagban saját génről vagy egy fehérje kódoló gén introni régiójából átíródó elsődleges transzkriptum a pri-miRNS, mely másodlagos struktúrákban gazdag. Az RNáz III típusú DROSHA hozza létre a pri-miRNS-ből a premiRNS-t, amit az exportin5 szállít a sejtmagból a citoplazmába, ahol újabb enzimatikus hasítás után létrejön a 21-23 nt hosszúságú miRNS duplex. Ezt a RISC komplex veszi fel és széttekeri a szálakat: míg a vezető szál a RISC-ben marad, addig a másik szál citoplazmatikus RNázok által degradálódik. Az érett miRNS-t tartalmazó RISC a miRNS-sel komplementer szekvenciájú mRNS 3' UTR régiójához hibridizál. Tökéletes komplementartiás esetén a komplex hasítja az mRNS-t, ami ezután lebomlik. Ha nem teljes a komplementaritás a RISC az mRNS deadenilációját indukálja és gátolja a transzlációt ([72] alapján módosítva).

A miRNS-ek target felismeréséért első sorban a seed régió felelős, mely a miRNS 27 nt pozícióiban elhelyezkedő 6 nt-os, erősen konzervált szekvenciája. A seed szekvenciák alapján a miRNS-ek miRNS gén családokba sorolhatók, melyek hasonló szekvenciájukból adódóan hasonló vagy azonos mRNS állomány célzott gátlásában vesznek részt. Számos miRNS klaszterekbe rendeződve helyezkedik el a genomban, melyek közös pri-miRNS-ként íródnak át, így kifejeződésük szabályozása is párhuzamosan zajlik. A miRNS-ek hatása redundáns, hiszen egy mRNS csendesítésében több miRNS is részt vehet, ugyanakkor egy miRNS-nek számtalan mRNS lehet a célpontja. A miRNS-ek általi szabályozás tehát nem kapcsoló jellegü, hanem inkább a génexpresszió finomhangolását teszi lehetővé [73]. 


\subsubsection{A miRNS-ek biogenezisének kapcsolata a daganatokkal}

A miRNS-ek biogenezisében résztvevő enzimek jelentősége a tumorok fejlődésében vitathatatlan. A DROSHA és DICER kifejezödésének csökkenése és a betegség rossz kimenetele közötti egyértelmü párhuzam figyelhető meg [74]. A tumor onkogénként funkcionáló transzkripciós faktor MYC csökkenti a Drosha kifejeződését és így a pri-miRNS hasítást, míg a tumor szupresszor TAp63 transzkripciós faktor hibája esetén elmarad a DICER promóterének aktivációja, így a DICER nem képes ellátni a feladatát a miRNS érésben $[75,76]$. A DICER és AGO2 epigenetikus csendesítését is megfigyelték a hipoxiás, daganatos szövetekben, tehát a miRNS biogenezis folyamata a daganatos sejtekben több szinten érintett [77].

\subsection{3. miRNS-ek a daganatos megbetegedésekben és az EMT-ben}

A tumor szuppresszor miRNS-ek kifejeződésének gátlása, míg az oncomiR-ek, azaz onkogén hatású miRNS-ek fokozott expressziója is jellemző a daganatokra. A tumor szupresszor miRNS-ek egyik legjobban jellemzett családja a miR-34 család, melynek tagjai, a miR-34a/b/c kritikus szerepet töltenek be a sejtciklus szabályozásában, a metasztázis folyamatában és a kemoterápiás szerek elleni rezisztencia kialakulásában [77]. A miR-34a expresszióját a p53 transzkripciós faktor szabályozza, közösen hozzájárulnak az apoptózis fokozásához. A miR-34 tumor gátló szerepe az általa szabályozott mRNS expresszióján keresztül érvényesül, például az anti-apoptótikus BCL2, illetve a Notch1 és Notch2 direkt gátlásán át, melyek kulcsfontosságúak az EMT szabályozásában. A miR-34 továbbá csökkenti a tumorfejlődésben kritikus szerepet betöltő c-Myc és c-Met kifejeződését [78]. A proto-onkogénként is ismert, azaz a tumor fejlődést serkentő AXL szabályozásában a miR34a mellett, a vele azonos seed régióval rendelkező, erősen konzervált miR-199a is részt vesz [79-81]. A tumorszuppresszor PPAR $\gamma$ által aktivált miR-92b fibroblaszt sejtekben csökkenti az AXL mRNS és ezáltal fehérje szintjét is $[82,83]$.

Ismert továbbá, hogy az EMT-ben jelentős szerepe van a MIR-8 család tagjainak (miR-200a/b/c,-141,-429), melyek a ZEB1 és ZEB2 transzkripciós faktorok gátlásán keresztül lassítják a tranzíció folyamatát [84]. Negatív visszacsatolás figyelhető meg 
közöttük, ugyanis a ZEB2 képes gátolni a miR-200b promoterén keresztül a transzkripciót [85]. Más tumor-szuppresszor miRNS-ek, például a miR-let-7 család tagjainak, továbbá a miR-143-nak és miR-145-nek a csökkent kifejeződését írták le többek között tüdö-, hasnyálmirigy, prosztata-, petefészek-, mell- és vastagbélrákban [77].

A daganatos megbetegedések vizsgálata során az egyik legtöbbet tanulmányozott oncomiR, a miR-155, mely például a VHL (von Hippel-Lindau tumor supressor) gátlásán keresztül fokozza az angiogenezist és a rákos sejtek túlélését [86]. Ezen kívül ismert oncomiR-ek még például a miR-10b, a miR-221 és a miR-222 [77].

\subsection{4. miRNS-ek a gyulladásos folyamatok szabályozásában}

Ahogy a fehérje kódoló mRNS-ek esetén, úgy a miRNS-ek csoportosítása során sem lehet szigorú határt húzni a tumoros és gyulladásos folyamatok szabályozásában résztvevő molekulák között. A gyulladás és az epiteliális-mezenhimális tranzíció molekuláris komponensei között átfedés és együttmüködés figyelhető meg. Az EMT-t aktiváló transzkripciós faktor, a TWIST1 a mir-192 gátlásával fokozza annak targetje, az EGR1 kifejeződését, ami gyulladáskeltő citokinek és növekedési faktorok, pl. az IL6, IL8, CXCL1 és FGF2 szintjének emelkedéséhez vezet [87]. Az IL6 ezután tovább erősíti a gyulladásos választ azáltal, hogy a MIR-8 géncsaládba tartozó mir-200c csökkent expresszióját idézi elő [88]. Az EMT-t aktiváló másik transzkripciós faktor, a SNAI1 a miR-375 gátlásával növeli a gyulladáskeltő jelátvitel kulcsszereplőinek, a JAK2, MAP3K8 és TP53 kifejeződését [8992]. Ennek a kaszkád mechanizmusnak a következő lépésében, a TP53 a miR-107 inhibítoraként, fokozza a NOTCH2, NES és MMP12 gének expresszióját [93-95]. Végül a miR-199a a SNAI1 és NFKB1 transzkripciós faktorok mellett, a HIF1 $\alpha$ és az N-cadherin $(\mathrm{CDH} 2)$ gátlásban is részt vesz, ezzel zárja a számtalan visszacsatolással finomhangolt szabályozó hálózatot [96-103].

A TLR receptorok által közvetített immunválasz során nemcsak a gyulladásos gének expressziója, hanem számos miRNS kifejeződése is megváltozik. Közülük a legtöbbet tanulmányozott miRNS-ek, a már korábban említett miR-155, valamint a miR-146a és miR21 megváltozott kifejeződését számos gyulladással összefüggő állapotban megfigyelték [104]. A miR-155 fokozza az immunválaszt, elsősorban a gyulladás negatív regulátorainak 
gátlásán keresztül. Targetjei pl. a SHIP1 és a SOCS1, melyek az AKT és az IFN válasz inhibítorai és a sejtek túlélését, növekedését, mozgékonyságát szabályozzák, valamint kulcsfontosságúak az antivirális válaszban. A miR-155 túltermelődése tehát krónikus gyulladáshoz vezet, míg gátlásával enyhül az immunválasz [104].

A miR-155-tel ellentétben, a miR-146a és miR-21 gátolják az immunválaszt aktiváló molekulák kifejeződését. A miR-146a a gyulladásos válasz negatív regulátora, amit a TLR jelátvitelben kulcsfontosságú TRAF6 és IRAK1 poszttranszkripcionális gátlásával ér el. A miR-146a expresszióját csakúgy, mint számos proinflammatórikus citokin kifejeződését NF-

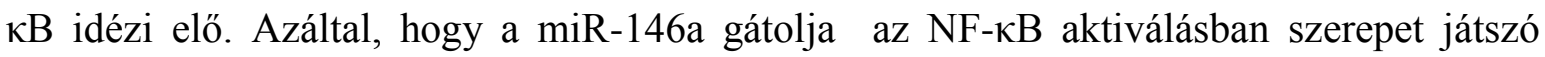
TRAF6 és IRAK1 szignál továbbító molekulák transzlációját, meggátolja a további NF-kB által kiváltott proinflammatórikus citokin termelést [104]. Ez a negatív visszacsatolás a gyulladásos válasz késleltetett csökkenését eredményezi. A miR-21 a miR-146a-hoz hasonlóan NF-אB hatására indukálódik, targetje a proinflammatórikus PDCD4, ami önmaga is képes az NF-kB aktiválására [104]. Ebben az esetben is egy késleltetett visszaható gátló mechanizmus figyelhető meg az PDCD4 - NF-אB - miR-21 - PDCD4 tengely mentén.

A veleszületett immunválasz kialakításában kulcsfontosságú TLR2/TLR4 jelátviteli útvonal gátlásában számos miRNS vesz részt, ilyenek például a teljesség igénye nélkül, a miR-145-t és miR-let7i-t [105], valamint a TNF $\alpha$ és az IL6 inhibítorai a miR-125b és a miRlet7 [104]. A gyulladásos folyamatok szabályozásának fontos résztvevője még a miR-223. A csontvelőből származó makrofágok (bone marrow-derived macrophages, BMDM) LPS illetve IL4 stimulációját követöen a miR-223 gátolja a proinflammatórikus TNF $\alpha$ és IL1 $\beta$ kifejeződését, így a makrofágok polarizációja a klasszikus M1 típus helyett a gyulladás-gátló alternatív M2 típus irányába tolódik el [106]. Szívmütétek során a megemelkedett TNF $\alpha$, IL6 és IL8 expresszió mellett a vérben jelentősen megnő a miR-223 tartalmú exoszómák mennyisége: a belölük izolált miR-223 monocitákban képes az IL6 és a TNFa, valamint az IL8 érésében fontos szerepet játszó NLRP3 expressziójának visszaszorítására [107].

Összességében elmondható, hogy a miRNS-ek szabályozó szerepe végigkövethető az immunválasz folyamatának minden egyes lépésében kezdve a gyulladás aktiválásától egészen a sejtek differenciálódásáig és motilitásáig. 


\subsection{5. miRNS-ek alkalmazása a gyógyászatban}

A mikroRNS-ekkel kapcsolatos terápiás elképzelések azon az elven alapulnak, mely szerint a miRNS-ek mennyiségének befolyásolásával megváltoztatható a cél mRNS-ek kifejeződésének mértéke. Ez kétféleképpen valósítható meg; egyrészt a miRNS-ek szintetikusan létrehozott másolatainak bejuttatásával (miRNA mimics), vagy az endogén módon, a szervezetben termelődő miRNS-ek gátlásával (AntimiRs). A miRNS-ek gyógyászati felhasználásához elengedhetetlen a potenciális miRNS-mRNS jelöltek felkutatása és funkcionális kapcsolatuk jellemzése. Ennek érdekében a beteg és egészséges mintapopulációk vizsgálta mellett szükséges in vivo rendszerek és in vitro sejtkultúrák alkalmazása, mellyel definiálhatók a miRNS-ek és targetjeik közötti interakciók [73, 77].

A klasszikus terápiás készítményekkel szemben, a miRNS-ek kifejeződésének megváltoztatása alternatív megoldásnak tekinthető, hiszen azok a szervezetben természetes körülmények között is jelen vannak, így az immunrendszer nem érzékeli őket betolakodóként. A miRNS-ek további elönye, hogy egyszerre több target molekula célzott szabályozására is képes lehet egyetlen miRNS, így párhuzamosan akár több szignalizációs útvonal aktivitása is befolyásolható általuk.

A miRNS-ek terápiás alkalmazását célzó kutatások az alapkutatás illetve a klinikai tesztelés különböző fázisaiban tartanak. A rendkívül alaposan jellemzett miR-34 tumor szupresszor exogén túltermeltetését például lipid nanopartikulumokba zárt, szintetikusan előállított miRNS-ek bejuttatásával már sikeresen tesztelték máj-, prosztata- és tüdőrákos egér modell rendszerekben, és jelenleg a fázis 1. klinikai vizsgálatok elvégzésénél tart a módszer tesztelése [77]. Másrészt az EGFR receptort célzó exogén miR-16 kezelés szignifikánsan csökkentette a tumor növekedést rágcsálókban, klinikai tesztelése szintén első fázisban tart [77].

A daganatos megbetegedések kezelése mellett, a mikroRNS-ek más kórképek, például 2-es típusú diabétesz, gomba és vírus fertőzések gyógyítására is alkalmas lehet [77]. Cukorbetegség esetén az antimiR-103/107 kezelés az inzulin jelátvitelben és érzékenységben szerepet játszó caveolin 1 szintjének emelkedését, így fokozott inzulin érzékenységet eredményezhet, amit egér modellben már sikeresen igazoltak is [77]. 
Emellett, a hepatitisz C fertőzések kezelésére is több miRNS alapú terápiás módszer irányul. A miRNS-ek jól ismert mRNS gátló hatásával ellentétben, a miR-122 képes fokozni a hepatitisz C vírus RNS genomjának replikációját [108]. Tehát a fertőzés visszaszorítása érdekében a miR-122 gátlását antimiR-122 bejuttatásával érik el, mellyel csökkenthető a vírus terjedése [77]. 


\section{CÉLKITÜZÉSEK}

Az immunmediált gyulladásos betegségek multifaktoriális eredetü kórképek, kialakulásukban szerepe van a környezeti, mikrobiális, immunológiai és genetikai faktoroknak és az ezek között létrejövő interakcióknak. A tápcsatorna krónikus gyulladásával járó, gyulladásos bélbetegségek (IBD) összes kiváltó okát mindezidáig nem sikerült feltárni, ami elsősorban a betegség komplex jellegéből adódhat. Az IBD egy élethosszig tartó betegség, melynek tünetei jelentősen csökkentik az életminőséget. A betegség kezelését és a tünetek enyhítését célzó új terápiás lehetőségek kifejlesztéséhez elengedhetetlen a betegség molekuláris hátterének minél pontosabb megértése in vivo és in vitro rendszerek, valamint IBD-s páciensekből származó minták vizsgálatán keresztül.

A fentieket szem elött tartva, a következő célokat tüztük ki:

1. A gyulladásos bélbetegségek tanulmányozására alkalmas in vivo rendszer finomhangolását, melyben az IBD-s betegeknél tapasztalt állapot pontosabb modellezése a cél.

2. Az in vivo modellből származó mintacsoportok teljes transzkriptóma vizsgálatát, majd az azonosított megváltozott kifejeződésủ és az IBD patogeneziségen releváns fehérje kódoló mRNS-ek és miRNS prekurzorok validálását QPCR módszerrel; valamint fehérje szinten immunfluoreszcens festéssel.

3. A transzkriptóma analízis során azonosított transzkriptumok között funkcionális kapcsolatok vizsgálatát, a gyulladásra jellemző molekuláris mintázatok és jelátviteli útvonalak meghatározását útvonal elemző szoftver segítségével.

4. A patológiás folyamtokban potenciálisan szerepet játszó gének és az azokat szabályozó miRNS-ek azonosítását és vizsgálatát IBD-s betegekben. 


\section{ANYAGOK ÉS MÓDSZEREK}

\subsection{In vivo kísérleti modell és mintagyüjtés}

Az IBD-s betegek vastagbelében fennálló gyulladás modellezésére hím Wistar patkányok (250-300 g) egyik csoportjának vastagbelében gyulladást indukáltunk trinitrobenzén szulfon sav (TNBS) rektális befecskendezése által, míg a kontroll csoporthoz tartozó állatok semmilyen kezelésben nem részesültek. 72 órával a kezelés után a patkányokat feláldoztuk, a disztális vastagbél szakaszokat eltávolítottuk. A belek jéghideg fiziológiás sóoldattal történt átmosása után, a TNBS kezelt állatok esetében mintát gyüjtöttünk a gyulladt (léziós) és az attól legalább $1 \mathrm{~cm}$ távolságra elhelyezkedő nemgyulladt területekből; míg a kontroll állatok esetében véletlenszerủen történt a mintavétel a vastagbélböl. A mintákat TRIzol (Thermo Fischer) reagensbe helyeztük és a további feldolgozásig $-80{ }^{\circ} \mathrm{C}$-on tároltuk.

\subsection{IBD-s betegek}

A humán minták begyüjtése az Egészségügyi Tudományos Tanács, Tudományos és Kutatásetikai Bizottság (ETT TUKEB) által kiadott 427-1/2012/EKU (13/PI/12.) ügyiratszámú szakmai-etikai engedélyben foglaltak szerint történt.

A humán vastagbél biopsziákat a Pécsi Tudományegyetemen, a Klinikai Központ I.sz. Belgyógyászati Klinikáján tapasztalt gasztroenterológusok gyüjtötték be a Magyar Egészségügyi Tudományos Tanács iránymutatásainak megfelelően és a további feldolgozásig $-80{ }^{\circ} \mathrm{C}$-on tárolták.

A vastagbél minták 15 IBD-s páciensből származnak (átlag \pm SD életkor $41 \pm 10 ; 10$ nő, 5 férfi). A minták gyüjtése és csoportosítása a betegség aktuális státusza, vagyis aktív/relapszáló vagy inaktív/remissziós fázis szerint történt. A szövet állapotának megfelelően, az aktív fázisban lévő betegek esetén a gyulladt/léziós és a nem-gyulladt/ép vastagbél régiókból is származnak minták. 


\subsection{RNS tisztítás}

A TRIzol reagensben tárolt patkány vastagbél mintákat ULTRA-TURRAX T-18 (IKA) homogenizátor segítségével homogenizáltuk. A homogenizátumból 0,3 ml-t 0,1 ml kloroformmal alaposan összekevertünk, majd 13000 rpm-en $4{ }^{\circ} \mathrm{C}$-on 10 percig centrifugáltunk. A felső, vizes fázisból RNeasy Plus Mini Kit (Qiagen) segítségével tisztítottunk totál RNS-t. Ehhez, a kloroformos kicsapást követően fennmaradó vizes fázist elegyítettük RLT pufferrel. A genomi DNS-t oszlopos módszerrel távolítottuk el, majd etanol hozzáadását követően RNeasy oszlopon kötöttük meg az RNS-t, amit RW1 és RPE pufferekkel mostunk, végül kétszer $10 \mu$ l nukleáz mentes vízzel eluáltuk a totál RNS-eket.

A humán izolátumokból a totál RNS izolálása Macherey-Nagel NucleoSpin RNA (Macherey-Nagel GmbH) kit felhasználásával történt a gyártó leírásának megfelelően.

Az RNS-ek mennyiségének és minőségének meghatározása 2 eszközzel történt: a) TapeStation 2200-as berendezéssel RNA Screen Tape-ek és reagensek használatával (mind Agilent) illetve b) Qubit Fluorometer készülékkel a Quant-iT RNA Assay kit (mind Thermo Fisher) használatával.

\subsection{Reverz transzkripció}

A cDNS szintézist reverz transzkripció során SuperScript VILO Master Mix (Thermo Fisher) segítségével hajtottuk végre a gyártó által javasolt protokollt betartva Veriti Thermal Cycler (Thermo Fisher) PCR berendezés segítségével az 1. táblázatban feltüntettet hőprofil szerint.

\section{1. táblázat: Reverz transzkripció hőprofilja}

Höfok

\begin{tabular}{llc}
\hline Primer hibridizáció & $25^{\circ} \mathrm{C}$ & 10 perc \\
\hline Reverz transzkripció & $42^{\circ} \mathrm{C}$ & 60 perc \\
\hline Enzim inaktiváció & $85^{\circ} \mathrm{C}$ & 5 perc \\
\hline
\end{tabular}




\subsection{Valós idejü kvantitatív polimeráz láncreakció}

Az mRNS-ek és pri-miRNS-ek kifejeződését valós idejü kvantitatív polimeráz láncreakcióval (real-time/quantitative polymerase chain reaction, QPCR) mértük StepOne és StepOnePlus PCR Systems (Thermo Fisher) berendezések segítségével. SybrGreen technológia alapú QPCR reakciók esetén SYBR Select Master Mix-et (Thermo Fisher) alkalmaztunk a 2. táblázatban feltüntetett hőprofil szerint az exon-exon határra tervezett specifikus primer párok használatával, melyeket a 3. táblázat tartalmaz.

\section{2. táblázat: SybrGreen alapú QPCR reakciók hőprofilja}

\begin{tabular}{llcc} 
& Hőfok & Inkubációs idő & Ismétlés \\
\cline { 1 - 3 } UDG aktiváció & $50{ }^{\circ} \mathrm{C}$ & 2 perc & \multirow{2}{*}{$1 \mathrm{x}$} \\
\cline { 1 - 3 } AmpliTaq DNS polimeráz UP aktiváció & $95^{\circ} \mathrm{C}$ & 2 perc & \\
\hline Denaturáció & $95{ }^{\circ} \mathrm{C}$ & 15 másodperc & \\
\cline { 1 - 4 } Primer hibridizáció és szintézis & $60{ }^{\circ} \mathrm{C}$ & 1 perc & \\
\hline Denaturáció & $95{ }^{\circ} \mathrm{C}$ & 15 másodperc & $1 \mathrm{x}$ \\
\hline Olvadáspont görbe felvétele & $60{ }^{\circ} \mathrm{C}$-tól $90{ }^{\circ} \mathrm{C}$-ig $0,5{ }^{\circ} \mathrm{C}$-onként & $1 \mathrm{x}$ \\
\hline
\end{tabular}




\section{3. táblázat: SybrGreen alapú QPCR során használt patkány (A.) és humán (B.) primerpárok}

A.

\begin{tabular}{|c|c|c|c|}
\hline Gén & Forward primer (5' - 3') & Reverse primer (5' - 3') & $\begin{array}{c}\text { Termék mérete } \\
\text { (nt) }\end{array}$ \\
\hline A4gnt & AATACCAGCAGCTACCCAGC & CCAGATAATAGCCAGGCGGG & 186 \\
\hline Cdh1 & CCACCAGATGACGATACCCG & GAATCACTTCCGGTCTGGCA & 124 \\
\hline Cxcl1 & CATTAATATTTAACGATGTGGATGCGTTTCA & GCCTACCATCTTTAAACTGCACAAT & 75 \\
\hline Dmbt1 & ATCTTGTACAGAGGCTCTTGGGTA & CCTGAACCCTGACCAAACCAA & 137 \\
\hline Egr1 & AACAACCCTACGAGCACCTG & AAAGGGGTTCAGGCCACAAA & 183 \\
\hline Fgf2 & GCGACCCACACGTCAAACTA & CCGTGACCGGTAAGTGTTGTA & 188 \\
\hline Fgf7 & TGTGGCAATCAAAGGGGTGG & AAGGCCACGAACATTTCCCC & 180 \\
\hline Fut1 & AGGACCCGTTTCTCAAGCTG & CTATCCGGAGCCCACTCAAC & 141 \\
\hline Fut2 & АСТTCСАССАТСАТССАССТС & CTCTGGGCTTTCTGTGTTTCC & 111 \\
\hline Fut4 & AAGCTACAGCATGAGAGCCG & AGAGGAGGTCCGGGGTAATC & 147 \\
\hline Fut9 & CAACAAATCCCATGCGGTCC & CAATGCCACTCTTTTGGGGG & 146 \\
\hline Hif1a & CTCATCCAAGGAGCCTTAACCT & TAACGTTCCAATTCCTGCTGC & 161 \\
\hline II1及 & CAGGAAGGCAGTGTCACTCA & AGACAGCACGAGGCATTTTT & 231 \\
\hline Il6 & TCTCCGCAAGAGACTTCCAG & CTGGTCTGTTGTGGGTGGTAT & 123 \\
\hline Jak2 & AGTGTGCTACAGTGCTGGTC & TTCCTTGTTGCCAGATCCCG & 198 \\
\hline Lox & AGGGCGGATGTCAGAGACTA & CATCCAGCAGGTCGTAGTGG & 175 \\
\hline Mmp13 & ACCCAGCCCTATCCCTTGAT & TCTCGGGATGGATGCTCGTA & 178 \\
\hline Mmp9 & GCCGGGAACGTATCTGGAAA & GGTTGTGGAAACTCACACGC & 177 \\
\hline Muc2 & ACCTACGGAGTCCACTACCC & TTGGCCCTGTTGTGGTCTTT & 194 \\
\hline Naip6 & GCATGGAGAATTGGAAGGAA & CAGACTCCTGGCCTCTTGAC & 247 \\
\hline Nlrc4 & GCGAAACCTGAAGAAGATGC & AACGCTCAGCTTGACCAAAT & 195 \\
\hline Nlrp3 & GCTGCTCAGCTCTGACCTCT & AGGTGAGGCTGCAGTTGTCT & 164 \\
\hline Nlrp6 & TACCTGGTCATTGTGCTCCA & TCAGAGGCTGAGGATGTGTG & 249 \\
\hline Nod1 & GCTCATCCGGACCAAAACTA & CTGCCCAGGTTTTCATTGTT & 188 \\
\hline Nod2 & TCCTTGCACACAAGCAGAAC & TGATCAGCCACAACTTCAGC & 180 \\
\hline Notch1 & ACAGTGCAACCCCCTGTATG & CCAGTCCATCCCACTCACAC & 101 \\
\hline Notch2 & ААCTGCACСТCСТCACTTCG & CTCCTCGTTGTTGCATCCCT & 186 \\
\hline Snai1 & CGGAAGCCCAACTATAGCGA & AGAGTCCCAGATGAGGGTGG & 147 \\
\hline Tnfo & ATGGGCTCCСTCTCATCAGT & GCTTGGTGGTTTGCTACGAC & 106 \\
\hline Vim & CATGCGGCTGCGAGAAAAAT & GGTCAAGACGTGCCAGAGAA & 113 \\
\hline Zeb2 & AAAGCAGTTCCCTTCTGCGA & AGGAGCCCGAGTGTGAAAAG & 180 \\
\hline pre-miR-27b & ССТСТCTAACAAGGTGCAGAGC & GCAGAACTTAGCCACTGTGAAC & 80 \\
\hline pri-miR-27b & TCACATTGCCAGGGATTACCA & AGCTAAGCTCTGCACCTTGTT & 210 \\
\hline
\end{tabular}


B.

\begin{tabular}{|c|c|c|c|}
\hline Gén & Forward primer (5' - 3') & Reverse primer (5' - 3') & $\begin{array}{c}\text { Termék mérete } \\
\text { (nt) }\end{array}$ \\
\hline CDH1 & AGCCTGTCGAAGCAGGATTG & AGTCCTGGTCCTCTTCTCCG & 204 \\
\hline EGR1 & ACCTGACCGCAGAGTCTTTT & GAGTGGTTTGGCTGGGGTAA & 84 \\
\hline FGF2 & GCAAAAACGGGGGCTTCTTC & AACGGTTAGCACACACTCCT & 144 \\
\hline FGF7 & TGGCAATCAAAGGGGTGGAA & CCCTCCGTTGTGTGTCCAT & 161 \\
\hline HIF1a & GCCGCTGGAGACACAATCAT & CGTTTCAGCGGTGGGTAATG & 168 \\
\hline JAK2 & GGAGTATGTGTCTGTGGAGACG & GCCCATGCCAACTGTTTAGC & 140 \\
\hline LOX & ACTGCACACACACAGGGATT & AGCTGGGGTTTACACTGACC & 130 \\
\hline MMP13 & AGGAGCATGGCGACTTCTAC & AGACCTAAGGAGTGGCCGAA & 181 \\
\hline MMP9 & TCTATGGTCCTCGCCCTGAA & GCACAGTAGTGGCCGTAGAA & 198 \\
\hline MUC2 & CTGCTATGTCGAGGACACCC & GAGTTGGTACACACGCAGGA & 84 \\
\hline NOTCH2 & GGATGGGCTGGTGCCTATTG & ACAGTAATGCGTGTTGCCAG & 132 \\
\hline pre-miR-192 & AGGGCTCTGACCTATGAATTGAC & CATTGAGGCGAACATACCTGTG & 88 \\
\hline pre-miR-223 & CGCTCCGTGTATTTGACAAGC & TGACAAACTGACACTCTACCACA & 60 \\
\hline pre-miR-27b & ССТСТСТAACAAGGTGCAGAGC & GCAGAACTTAGCCACTGTGAAC & 80 \\
\hline pri-miR-27b & TCACATTGCCAGGGATTACCA & AGCTAAGCTCTGCACCTTGTT & 210 \\
\hline SNAI1 & ACCCCAATCGGAAGCCTAAC & GGACAGAGTCCCAGATGAGC & 159 \\
\hline VIM & GGACCAGCTAACCAACGACA & AAGGTCAAGACGTGCCAGAG & 178 \\
\hline ZEB2 & CCAAGGAGCAGGTAATCGCA & ACGTTTCTTGCAGTTTGGGC & 133 \\
\hline
\end{tabular}

TaqMan alapú reakciók esetén TaqMan Fast Advanced Master Mix-et (Thermo Fisher) és TaqMan Gene Expression Assay-ket (5. táblázat; Thermo Fisher) alkalmaztunk a 4. táblázatban feltüntetett hőprofil szerint.

\section{4. táblázat: TaqMan alapú QPCR reakciók hőprofilja}

Hőfok Inkubációs idő Ismétlés

\begin{tabular}{llcc}
\hline UDG aktiváció & $50{ }^{\circ} \mathrm{C}$ & 2 perc & \multirow{2}{*}{$1 \mathrm{x}$} \\
\hline Polimeráz aktiváció & $95^{\circ} \mathrm{C}$ & 20 másodperc & \\
\hline Denaturáció & $95^{\circ} \mathrm{C}$ & 1 másodperc & \multirow{2}{*}{$40 \mathrm{x}$} \\
\hline Primer hibridizáció és szintézis & $60{ }^{\circ} \mathrm{C}$ & 20 másodperc & \\
\hline
\end{tabular}


5. táblázat: TaqMan alapú QPCR során használt assay-k $(R n=$ Rattus norvegicus - patkány; Hs = Homo sapiens - ember)

\begin{tabular}{|c|c|}
\hline Gén & Assay szám \\
\hline 18S rRNS & Hs99999901_s1 \\
\hline Axl & Rn01457771_m1 \\
\hline AXL & Hs00242357_m1 \\
\hline Ccl3 & Rn01464730_g1 \\
\hline Gas6 & Rn00588984_m1 \\
\hline IL1a & HSs00174092_m1 \\
\hline IL6 & Hs00174131_m1 \\
\hline Mertk & Rn00576094_m1 \\
\hline MERTK & Hs01031979_m1 \\
\hline Pros1 & Rn01527321_m1 \\
\hline TNFa & Hs00174128_m1 \\
\hline Tyro3 & Rn00567281_m1 \\
\hline TYRO3 & Hs00170723_m1 \\
\hline
\end{tabular}

Minden kísérletet legalább 3 biológiai és két technikai párhuzamossal végeztünk, melyekből a génexpresszió változását a $2^{-\Delta \Delta \mathrm{CT}}$ módszerrel állapítottuk meg, a $18 \mathrm{~S}$ rRNS-hez mint normalizáló kontrollhoz viszonyítva.

\section{6. miRNS valós idejü kvantitatív polimeráz láncreakció}

A miRNS-ek reverz transzkripciója TaqMan MicroRNA Reverse Transcription Kit és miRNS specifikus primerekkel (mind Thermo Fisher) történt a gyártói protokoll szerint, melynek hőprofilját a 6 . táblázat tartalmazza.

6. táblázat: miRNS reverz transzkripció hőprofilja

\begin{tabular}{llc} 
& Hőfok & Inkubációs idő \\
\hline Primer hibridizáció & $16^{\circ} \mathrm{C}$ & 30 perc \\
\hline Reverz transzkripció & $42^{\circ} \mathrm{C}$ & 30 perc \\
\hline Enzim inaktiváció & $85^{\circ} \mathrm{C}$ & 5 perc \\
\hline
\end{tabular}

A miRNS-ek kifejeződését TaqMan Universal PCR Master Mix és TaqMan Small RNA Assays-kel (mind Thermo Fisher, 8. táblázat) mértük StepOne és StepOnePlus PCR 
Systems (Thermo Fisher) berendezések segítségével a 7. táblázatban található hőprofil szerint. A miRNS expresszió változását $2^{-\Delta \Delta C T}$ módszerrel számítottuk ki, az U6 vagy RNU48 snRNS-ekhez mint normalizáló kontrollokhoz viszonyítva.

7. táblázat: miRNS QPCR hőprofilja

Hőfok Inkubációs idő Ismétlés

\begin{tabular}{lccc}
\hline Polimeráz aktiváció & $95^{\circ} \mathrm{C}$ & 10 perc & $1 \mathrm{x}$ \\
\hline Denaturáció & $95^{\circ} \mathrm{C}$ & 15 másodperc & \multirow{2}{*}{$40 \mathrm{x}$} \\
\cline { 1 - 3 } Primer hibridizáció és szintézis & $60^{\circ} \mathrm{C}$ & 1 perc & \\
\hline
\end{tabular}

\section{8. táblázat: miRNS specifikus TaqMan assay-k}

\begin{tabular}{ll}
\hline \multicolumn{1}{c}{ miRNS } & \multicolumn{1}{c}{ Assay szám } \\
\hline mir-107 & tm000443 \\
\hline mir-125a & tm002198 \\
\hline miR-141 & tm000463 \\
mir-143 & tm $463509-m a t$ \\
\hline mir-145 & tm002278 \\
mir-192 & tm000491 \\
\hline miR-199a & tm002304 \\
\hline miR-200a & tm000502 \\
\hline mir-200b & tm002251 \\
\hline mir-200c & tm002300 \\
\hline miR-215 & tm 464058 mat \\
\hline miR-223 & tm000526 \\
\hline mir-27b & tm000409 \\
\hline mir-30a & tm000417 \\
\hline mir-375 & tm000564 \\
\hline miR-429 & tm001077 \\
\hline mir-let7i & tm002221 \\
\hline RNU48 & tm001006 \\
\hline U6 snRNA & tm001973 \\
\hline
\end{tabular}




\subsection{Teljes transzkriptóma szekvenálás (RNS szekvenálás; RNS-Seq)}

Az RNS-Seq SOLiD Total RNA-Seq Kit (Thermo Fisher) felhasználásával SOLiD 5500 XL System szekvenáló berendezésen történt a gyártói utasítások betartásával. Röviden, az rRNS depletálását a patkány vastagbél totál RNS mintákból RiboMinus Eukaryote Kit-tel (Thermo Fisher) hajtottuk végre, majd a maradvány RNS fragmentálását RNáz III enzimmel végeztük. Az RNS fragmentek méreteloszlását Bioanalyzer 2100 (Agilent) készülék segítségével ellenőriztük. SOLiD adaptor mix-szel hibridizáltuk és ligáltuk az RNS fragmenteket, majd SOLiD RT primer és ArrayScript Reverse Transcriptase enzim segítségével cDNS-é írtuk át a konstruktokat. A cDNS tisztításához és méret szerinti elválasztásához Agencourt AMPure XP reagenst (Beckman Coulter) használtunk. A cDNS amplifikáció AmpliTaq DNS polimerázzal történt SOLiD 5' és Barcoded SOLiD 3' PCR primerek segítségével. A könyvtárak koncentrációját SOLiD Library TaqMan Quantitation Kit segítségével határoztuk meg. A cDNS könyvtárak klonális amplifikációját SOLiD P1 gyöngyök felhasználásával emulziós PCR-rel (ePCR) hajtottuk végre. Ezután a butanollal feltört emúlziókból a templátot tartalmazó ePCR gyöngyöket mágneses gyöngyök segítségével dúsítottuk. A klonálisan felamplifikált DNS könyvtárakat tartalmazó gyöngyöket szekvenáló lemezre helyeztük és újgenerációs szekvenálási módszerrel (SOLiD 5500 XL System, Life Technologies) 50 bp szekvánálási kémiával megszekvenáltuk.

\subsection{A RNS-Seq bioinformatikai kiértékelése}

A nyers szekvencia adatok méret szelekciója során az 50 bp-nál rövidebb leolvasásokat elhagytuk. CLC Genomic Workbench (Qiagen) program használatával a génexpressziós értékek kiszámítása érdekében, meghatároztuk minden mintában az egyes annotált génekre térképeződő leolvasások számát a következő CLC RNS-Seq analízis paraméterek szerint: az adott leolvasáson belüli eltérések maximuma 2, a hasonlósági frakció értéke 0,8. Az így meghatározott adatokat az R programba importáltuk (R Core Team, 2014; http://www.R-project.org/). A gének szürése során csak azokat tartottuk meg, melyekbe legalább 5 leolvasás térképeződött a vizsgált minták legalább 25 \%-ában. Ezek után az edgeR programcsomag "calcNormFactors" alkalmazásával [109], a "trimmed mean of M-values" (TMM) [110] módszer szerint normalizáltuk az adatokat. A log transzformációt és a kvantilis 
normalizálást a "limma" csomag "voom" funkciójával hajtottuk végre [111]. A legalább kétszeres expressziós különbséget mutató és 0,05-nél alacsonyabb FDR (False Discovery Rate) értékkel rendelkezö génexpressziós adatokat tekintettük szignifikáns változásnak. A többdimenziós skálázás használatával (“plotMDS” funkció az edgeR-ben) az egyes minták közötti transzkripciós hasonlóságok és különbségek vizuális megjelenítését hajtottuk végre, majd klaszter analízist követően az R programcsomag "heatmap.2" funkciójával hőtérképen ábrázoltuk a szignifikánsan változó normalizált adatok eloszlását (https://rdrr.io/cran/gplots/).

\subsection{Az RNS-Seq funkcionális analízise Ingenuity Pathway analysis (IPA) alkalmazással}

A transzkriptóma szekvenálás során meghatározott génexpressziós adathalmazban a molekulák közötti funkcionális kapcsolatok azonosítására az Ingenuity Pathway Analysis (IPA) webes alkalmazást használtuk (http://www.ingenuity.com), melynek Knowledge Base nevü adatbázisa a szakirodalomban publikált eredményeken alapul. A bioinformatikai feldolgozás során azonosított, a változás mértékét mutató log fold change és a statisztikai relevanciát tükröző False Discovery Rate $(F D R)$ értékek használatával a „core” analízis során meghatároztuk a jelentősen aktiválódott kanonikus szignalizációs útvonalakat a patkány vastagbél minták mindhárom csoportjának összehasonlítása esetén. A meghatározás a Reight-Tailed Fischer's Exact formula alapján történt, ami a hasonlóságot tükrözi egy adathalmaz szignifikánsan változó elemei, jelen esetben a gének közötti kapcsolati háló és egy korábban definiált folyamat vagy szignalizációs útvonal között. Az interakciók leírásának másik módja a z-érték alapján történhet, amely > 2 vagy $<-2$ esetén tekinthető szignifikánsnak és lehetőséget biztosít arra, hogy meghatározzuk a valószínűségét a kapcsolatok iránya és az abból adódó génexpresszió változás közötti korrelációnak.

\subsection{Metszetkészítés és immunfluoreszcens festés}

A patkány vastagbelek beágyazása Technovit 7100 protokoll alapján történt. A blokkokból Reichert Jung 1140 Autocut mikrotómmal $7 \mu \mathrm{m}$-es metszeteket készítettünk. 
A patkány vastagbél metszetek köré Daco Pen S2002 (Agilent) segítségével a folyadékok számára átjárhatatlan, vízálló, alkoholban és acetonban oldhatatlan réteget hoztunk létre. A mintákat $200 \mu 1$ 0,1\% TritonX-et (Sigma) és 5\% szérumot (Fetal bovine serum (FBS); Thermo Fisher) tartalmazó PBS-el (egységesen PBT) blokkoltuk 20 percig, szobahőmérsékleten. A blokkolást követően a mintákat egér anti-Axl (1:100; Santa Cruz) ellenanyagot tartalmazó PBT oldattal inkubáltuk egy éjszakán át $4^{\circ} \mathrm{C}$-on. Ezután a metszeteket háromszor 5 percig PBT-vel mostuk, majd 90 percig sötétben inkubáltuk FITCel konjugált anti-egér IgG (1:250; Sigma) másodlagos ellenanyaggal. Háromszor 5 perces PBT-s mosás után, a metszeteket 5 percig inkubáltuk DAPI-t (1:10000; 4',6-diamidino-2phenylindole) tartalmazó PBT-vel. 5 perces PBT-s mosást követően a metszeteket Citifluorral (Citifluor) fedtük, amely megakadályozza a fluorescens jel kioltását. Az így elkészített mintákat Zeiss Axio Observer Z1 epifluoreszcens mikroszkóppal elemeztük.

\subsection{Statisztikai analízis és ábrázolás}

A feltüntetett adatok minden esetben legalább három független biológiai mintán mért értékek átlagai \pm SEM. Az ábrákat GraphPad Prism 6 programmal készítettük; a statisztikai analízishez IBM SPSS 19 Statistics szoftvert használtunk. Az adatok feldolgozása, a szignifikancia megállapítása ANOVA analízissel történt LSD-, valamint Bonferroni-tesztek alkalmazásával. Az egyes értékek közötti különbséget szignifikánsnak a $\mathrm{p} \leq 0,05$ teljesülése esetén tekintettük. 


\section{EREDMÉNYEK}

\subsection{A gyulladásos bélbetegségek vizsgálatára alkalmazott rendszerek}

\subsubsection{In vivo TNBS indukált patkány IBD modell}

A gyulladásos bélbetegségek molekuláris hátterének tanulmányozására a 2,4,6trinitrobenzol-szulfonsav (TNBS) által indukált in vivo patkány modellt használtuk, melyet elsőként Morrison és munkatársai írtak le és az IBD általánosan elfogadott rágcsáló modelljévé vált $[112,113]$. A kezelés során a rektálisan beinjektált etanolban oldott TNBS, megbontja a nyálkahártya integritását, továbbá a TNBS mint haptén vegyület, a szöveti fehérjékkel komplexet alkotva immunreakciót vált ki. A kezelt állatokra jellemzö a súlyvesztés, a véres széklet, a mukóza, a szubmukóza és akár mélyebb szöveti rétegek gyulladása is. A legnagyobb szövettani és génexpressziós hasonlóság az IBD-s betegekkel, a patkányok három napos TNBS kezelése esetén tapasztalható [114].

A TNBS kezelt állatok vastagbelében gyulladt és nem-gyulladt szakaszok váltják egymást, épp úgy ahogy az IBD esetén is megfigyelhető, ahol a tápcsatorna mentén szintén felváltva helyezkednek el a gyulladt, léziós területek és a makroszkópikusan érintetlen, ép szöveti régiók [46]. A mintagyüjtés hagyományos módon hosszanti irányban történik a TNBS kezelt patkány vastagbelekből. Fontos kiemelni azonban, hogy a kezelést követően a biológiai párhuzamosok vastagbelei eltérő arányban tartalmaznak gyulladt és nem-gyulladt szövetrégiókat. Ennek következményeként a hagyományos hosszanti mintagyüjtési eljárással izolált mintákban különböző mértékben vannak jelen az ép, azaz nem-gyulladt valamint a gyulladt szakaszok, ami akár azt is eredményezheti, hogy a kisebb mértékben változó kifejeződésű gének esetében a szövetrégiók közötti transzkripcionális különbségek elfedik a valódi expressziós eltéréseket.

Munkahipotézisünk szerint a heveny gyulladásban lévő szövetek mellett, a látszólag intakt vastagbél szakaszokban is bekövetkezhetnek az immunválaszt befolyásoló változások, ezért a mintagyüjtés során ezeket megkülönböztettük. A TNBS kezelt állatok vastagbeléböl a sérült, tehát gyulladt (6. ábra, piros keret) illetve az attól jól elkülönülő tehát nem közvetlen a gyulladás mellett elhelyezkedő, fenotípusosan normális, azaz nem-gyulladt területekről (6. 
ábra, kék keret) is gyüjtöttünk szövetmintákat. A kontroll csoportba tartozó patkányok vastagbeléből ezzel szemben véletlenszerüen történt a mintavétel (6. ábra, zöld keret).

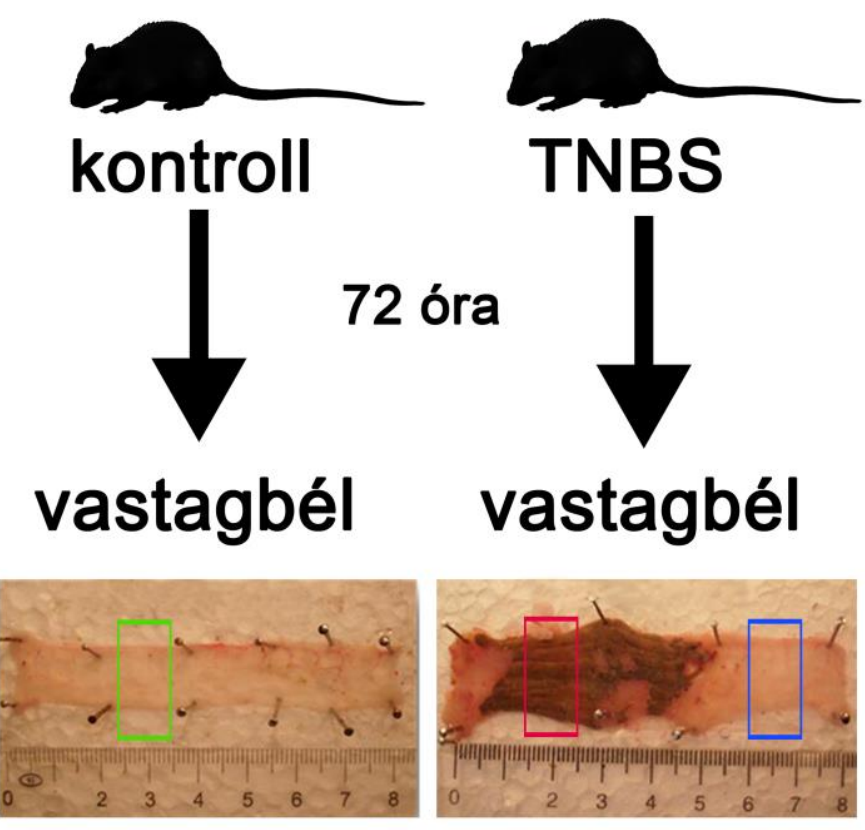

6. ábra: A kísérletesen kiváltott vastagbélgyulladás in vivo patkány modellje. Az intrarektálisan beinjektált TNBS 72 órás inkubáció után markáns gyulladást eredményezett a kezelt állatok vastagbelében. A TNBS kezelt állatok vastagbelének léziós - gyulladt (piros keret) és makroszkópikusan ép - nem-gyulladt (kék keret) szakaszaiból, míg a kontroll patkányok vastagbeléböl random módon történt a mintavétel az ép szövetből (zöld keret).

A szövetmintákból totál RNS-t izoláltunk, melyet RNS-Seq és QPCR eljárások során a teljes transzkriptómában bekövetkező változások azonosítására és validálására használtunk fel. Ezen kívül szöveti metszeteket is készítettünk, melyek immunofluoreszcens festését követően fehérje szinten is nyomon követtük a TNBS kezelés hatására eltérő expressziójú molekulák mennyiségi változását a vastagbélben.

\subsubsection{IBD-s betegek vastagbélmintáinak vizsgálata}

A kísérletesen kiváltott vastagbélgyulladás transzkriptóma analízise során a szöveti sejtalkotók és az általuk expresszált molekulák közötti kölcsönhatások eredményeképpen kialakult aktuális génexpressziós mintázatot figyelhetjük meg (lásd később). Az in vivo rendszerek fontos előnye, hogy a környezeti és genetikai faktorok kontrollálhatóak, továbbá az egyes állatokban, a biológiai párhuzamosokban kiváltott gyulladás időben precízen összehangolható. Azonban ez a rendszer mégiscsak egy állatmodell, amelyben nem 
lehetséges paraméterezni a vizsgált betegséget kialakító összes tényezőt - például a genetikai és életmódbeli különbségeket - melyek egyértelmü hatást gyakorolnak a betegség megjelenésére és lefolyására [47]. Ezért fontosnak tartottuk, hogy a patkány modellben elvégzett transzkriptóma analízis során nyert eredményeket a gyulladásos bélbetegségekben szenvedő páciensekből izolált mintákban is megvizsgáljuk. Ahogy a patkány modellben is tettük, a humán izolátumok begyüjtése során is megkülönböztettük az aktív/relapszáló stádiumú betegek esetén a vastagbél gyulladt (léziós) és makroszkópikusan normális, azaz nem-gyulladt szakaszait, melyeket inaktív stádiumban lévő betegekből származó mintákhoz viszonyítottunk.

\subsection{TNBS által kiváltott in vivo IBD modell teljes transzkriptóma analízise}

\subsubsection{RNS-Seq és annak bioinformatikai feldolgozása}

A korábban részletezett három elkülönített mintacsoportból - amelyeket a továbbiakban kontroll (K), TNBS kezelt gyulladt (GY) és TNBS kezelt nem-gyulladt (NGY) patkány vastagbél mintákként fogok nevezni - tisztított totál RNS-ből a mennyiségi és minőségi ellenőrzése után szekvenáló könyvtárakat készítettünk, melyeket SOLiD újgenerációs szekvenáló rendszeren szekvenáltunk meg. A nyers leolvasások bioinformatikai feldolgozása során, az annotált patkány referencia genomra illesztett szekvencia szakaszok mintán belüli és a minták közötti mennyiségi összehasonlítása révén meghatároztuk az egyes gének expressziójának változását a három mintacsoport között.

Az egyes minták közötti transzkripciós hasonlóságok és különbségek globális feltérképezését többdimenziós skálázás (multidimensional scaling, MDS) segítségével hajtottuk végre, melynek célja a vizsgált biológiai párhuzamosok csoportosítása és az esetlegesen kilógó minták azonosítása. Az MDS a hasonló transzkripciós mintázattal rendelkező patkány vastagbél mintákat egy-egy csoportba klaszterezte (7A. ábra). Az MDSel azonban nemcsak azt állapítottuk meg, hogy az általunk azonos mintacsoportba makroszkopikusan megfigyelhető tulajdonságok alapján besorolt egyedi szövetminták transzkripciós szinten is valóban egy csoportba tartoznak, hanem azt is, hogy a három csoport, tehát a kontroll, nem-gyulladt és gyulladt csoport egymástól teljesen elkülönül (7A. 
ábra). A szignifikánsan változó transzkriptek hőtérképen való ábrázolása esetén is megfigyelhetök a csoportok között különbségek, illetve az egy csoportba sorolt minták közötti globális transzkripciós hasonlóságok (7B. ábra).
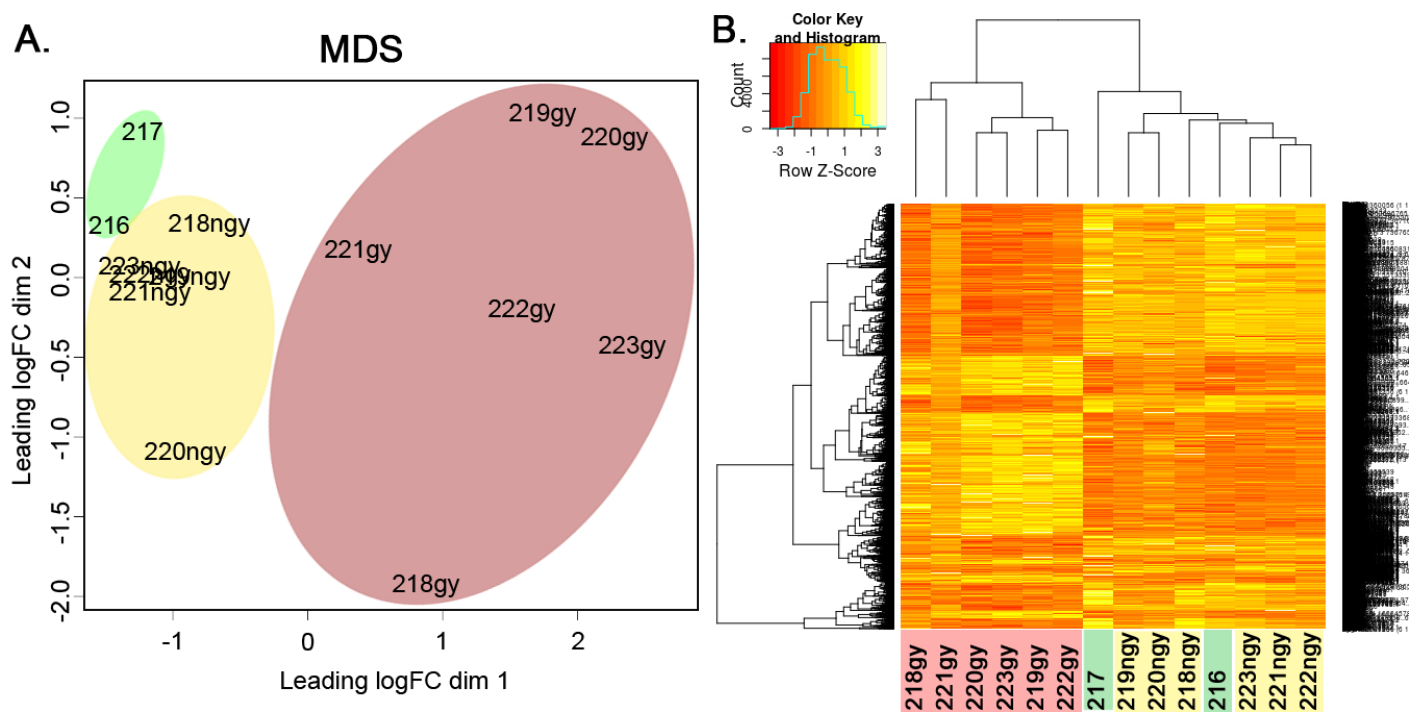

7. ábra: A TNBS által kiváltott patkány IBD modell vizsgálata során létrehozott in vivo mintacsoportok közötti transzkripciós hasonlóságok és különbségek globális feltérképezése. (A) A többdimenziós skálázással (multidimensional scaling, MDS) az egyedi patkány vastagbél minták közötti génexpressziós átfedéseket definiáltuk; melyek a három mintacsoportnak megfelelően a kontroll (zöld), TNBS kezelt nem-gyulladt (sárga) és TNBS kezelt gyulladt (piros) csoportokba klasztereződtek. (B) Az egyedi mintákban szignifikánsan változó transzkriptek reprezentatív ábrázolása hőtérképen: kontroll (zöld), TNBS kezelt nemgyulladt (sárga) és TNBS kezelt gyulladt (piros). A minta azonosítószámok az ábrákon: kontroll: 216, 217; nem-gyulladt: 218ngy, 219ngy, 220ngy, 221ngy, 222ngy, 223ngy; gyulladt: 218gy, 219gy, 220gy, 221gy, 222gy, 223gy.

Mivel két különböző módszerrel is arra a következtetésre jutottunk, hogy a TNBSkezelt állatokban a nem-gyulladt és gyulladt szakaszok transzkripcionális szinten teljesen különbözőek, ezért a módosított mintagyüjtési eljárást indokoltnak és relevánsnak találjuk a hagyományos módszerrel szemben a TNBS által kiváltott vastagbélgyulladás vizsgálata során [115].

A három csoportnak megfelelően így három különböző összehasonlításra nyílt lehetőségünk és ennek megfelelően el is végeztük a nem-gyulladt vs. kontroll, gyulladt vs. kontroll és a gyulladt vs. nem-gyulladt összehasonlításokat. Az összesen a mintákban azonosított - tehát legalább egy mintában detektált - több mint 26319 transzkriptböl, közel 3800 változott szignifikánsan valamely két csoport között (8. ábra). 

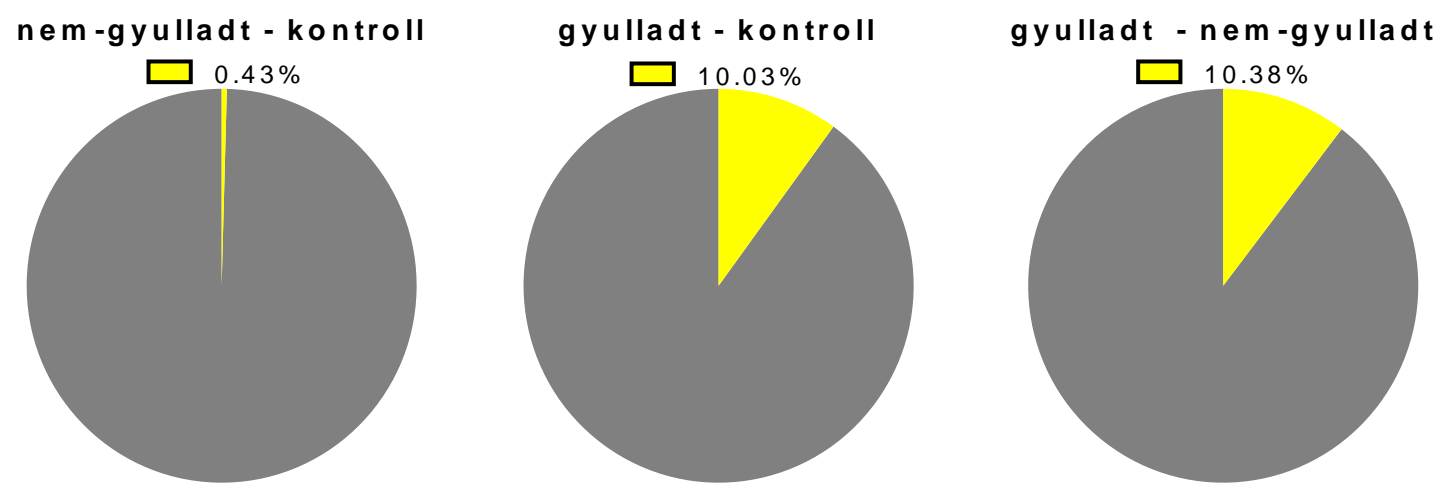

8. ábra: A transzkriptóma analízis során szignifikánsan változó transzkriptek százalékos eloszlása az összes azonosított transzkriptből. A nem-gyulladt vs. kontroll, gyulladt vs. kontroll és a gyulladt vs. nem-gyulladt minták összehasonlítása során a legnagyobb génexpressziós eltérést a gyulladt mintákban tapasztaltuk, ellenben a kontroll és nem-gyulladt minták között csekély mértékü eltérést tapasztaltunk. (Sárga jelöli a szignifikánsan változó kifejeződésü transzkripteket százalékos arányát az összes azonosított transzkripthez viszonyítva.)

A legtöbb eltérő kifejeződésủ transzkriptet a gyulladt mintákban azonosítottuk, ahol a kontroll illetve a nem-gyulladt mintákhoz történő hasonlítás esetén is, a detektált gének 10\%-a érintett, azaz 2639 és 2731 transzkript kifejeződése változott szignifikánsan. Ellenben a kontroll és TNBS-kezelt nem gyulladt minták génexpressziós mintázata nagyon hasonló, szignifikáns különbség csak az RNS-Seq során azonosított gének 0,43 \%-ánál, azaz 113 transzkriptnél figyelhető meg. Ez a kismértékủ eltérés az összes transzkriptet vizsgáló MDS esetén elegendő a kontroll és nem-gyulladt minták külön klaszterezéséhez (7A. ábra); azonban a csak szignifikánsan változó transzkripteket reprezentáló hőtérképen, a kontroll és a TNBS kezelt nem-gyulladt minták nem különíthetőek el (7B. ábra).

\subsubsection{A teljes transzkripciós változások funkcionális analízise}

Az RNS-Seq során azonosított génexpressziós adathalmazban a gének közötti funkcionális kapcsolatok feltárására az Ingenuity Pathway Analysis (IPA) webes alkalmazást használtuk, melynek adatbázisa a szakirodalomban publikált eredményeken alapul, így alkalmas az azonosított gének közötti globális kapcsolatok feltárására és egyszerübb értelmezésére. 
A bioinformatikai feldolgozás során számolt, a génexpresszió változás mértékét mutató log fold change $(\log \mathrm{FC})$ és a statisztikai relevanciát tükröző FDR (False Discovery Rate) értékek használatával a „,core” analízis során azonosítottuk a szignifikánsan változó kanonikus szignalizációs útvonalakat mindhárom összehasonlítás esetén. Az útvonalelemzés során meghatározott jelátviteli útvonalak esetén a p-érték tükrözi a szignifikancia mértékét, ami itt az áttekinthetőség érdekében - $\log (p$-érték) formában szerepel: tehát minél nagyobb az érték, annál valószínűbb, hogy a feltárt kapcsolat releváns (9. táblázat).

9. táblázat: Az IPA által azonosított szignifikánsan megváltozott kanonikus útvonalak. Az értékek - log(pérték) formában szerepelnek a táblázatban (N/A=nem értelmezhető adat).

\begin{tabular}{|c|c|c|c|}
\hline Ingenuity Kanonikus Útvonalak & $\begin{array}{c}\text { NGY - K } \\
\text { log(p-érték) }\end{array}$ & $\begin{array}{c}\text { GY - K } \\
\text { log(p-érték) }\end{array}$ & $\begin{array}{c}\text { GY - NGY } \\
\text { log(p-érték) }\end{array}$ \\
\hline Granulocita adhézió és diapedézis & N/A & 18,00 & 19,00 \\
\hline Agranulocita adhézió és diapedézis & N/A & 13,40 & 16,00 \\
\hline Leukocita infiltráció jelátvitel & N/A & 11,80 & 8,01 \\
\hline Májfibrózis / Máj csillagsejtek aktivációja & N/A & 11,30 & 13,70 \\
\hline Makrofágok, fibroblaszt sejtek, endotélsejtek szerepe reumatoid artritiszben & N/A & 8,19 & 9,20 \\
\hline IL-10 jelátvitel & N/A & 7,90 & 7,31 \\
\hline Érszükület (Atherosclerosis) jelátvitel & N/A & 7,84 & 11,60 \\
\hline Fagoszóma képződés & N/A & 7,52 & 6,55 \\
\hline Oszteoblasztok, oszteoklasztok és kondrociták szerepe reumatoid artritiszben & N/A & 6,40 & 4,33 \\
\hline TREM1 jelátvitel & N/A & 5,70 & 11,30 \\
\hline RXR funkciók gátlásának szabályozása LPS/IL-1 által & 1,74 & 5,62 & 10,60 \\
\hline Oxidatív foszforiláció & N/A & 5,59 & 18,50 \\
\hline Máj kolesztázis (epepangás) & N/A & 5,21 & 8,08 \\
\hline Akut fázis reakció szabályozása & N/A & 5,17 & 6,13 \\
\hline LXR/RXR aktiváció & N/A & 5,09 & 10,10 \\
\hline Mitokondriális működési zavar & N/A & 5,04 & 16,40 \\
\hline Retionát bioszintézis I & 3,34 & 4,77 & 2,79 \\
\hline Mártix metalloproteinázok gátlása & N/A & 4,56 & 5,33 \\
\hline Dendritikus sejtek érése & N/A & 3,85 & 4,31 \\
\hline Mintázatfelismerő receptorok szerepe a baktériumok és vírusok felismerésében & N/A & 3,82 & 5,19 \\
\hline NF-kB jelátvitel & 1,35 & 3,81 & 4,27 \\
\hline Axonális vezérlés jelátvitel & 1,31 & 3,77 & 2,44 \\
\hline IL-6 jelátvitel & N/A & 3,71 & 4,65 \\
\hline PPAR jelátvitel & N/A & 3,51 & 4,50 \\
\hline Xenobiotikus anyagcsere jelátvitel & N/A & 3,23 & 4,50 \\
\hline PPAR $\alpha / R X R \alpha$ aktiváció & 1,31 & 3,20 & 3,29 \\
\hline Veleszületett és adaptív immunsejtek közötti kommunikáció & N/A & 2,88 & 5,27 \\
\hline Megváltozott T sejt és B sejt jelátvitel reumatoid artritiszben & N/A & 2,67 & 5,02 \\
\hline C- vitamin antioxidáns hatása & N/A & 2,48 & 6,20 \\
\hline FXR/RXR aktiváció & N/A & 2,40 & 6,63 \\
\hline VDR/RXR aktiváció & N/A & 2,11 & 4,91 \\
\hline Embrionális őssejtek pluripotenciája & 1,63 & 1,56 & 1,37 \\
\hline STAT3 jelátviteli útvonal & 1,36 & N/A & 1,71 \\
\hline
\end{tabular}


Megállapítottuk, hogy a legjelentősebben aktiválódott útvonalak a gyulladt területeken az immunsejtek közötti kommunikációval (Veleszületett és adaptív immunsejtek közötti kommunikáció), az immunsejtek toborzásával (Leukocita infiltráció jelátvitel), a veszély jelek felismerésével (Mintázatfelismerö receptorok szerepe a baktériumok és virusok felismerésében), a gyulladásos válasz szabályozásával (Akut fázis reakció szabályozása), valamint a szövetek védelmével (Mártix metalloproteinázok gátlása) és regenerálásával (Fagoszóma képződés) kapcsolatosak (9. táblázat). Akár a kontroll akár a TNBS kezelt nemgyulladt területekhez viszonyítunk, a TNBS kezelt gyulladt területeken jelentősen megváltozott a leukociták, köztük az agranulociták és granulociták véráramból a gyulladt szöveti állományba való vándorlását segítő molekulákat magába foglaló szignalizációs útvonalak aktivitása. Érdemes kiemelni még a $N F-\kappa B$ és STAT3 jelátvitel aktiválódását a gyulladt szövetekben, melyek számos gyulladásban kulcsfontosságú szignalizációs útvonalat kapcsolnak össze, köztük például az IL10, IL6 és TREM1 jelátviteli útvonalakat (9. táblázat).

Az útvonal elemzés során az interakciók iránya és az abból adódó génexpresszió változás közötti korreláció leírására a legalkalmasabb a z-érték (z-score). A z-érték segítségével ugyanis nem csak azt tudhatjuk meg, hogy egy útvonal elemeinek megváltozott a kifejezödése, hanem azt is, hogy a közöttük már korábban kísérletesen igazolt szabályozó kapcsolatnak - pl.: aktiválás, gátlás - megfelelően változik-e expressziójuk az aktuális kísérleti felállásban. A z-érték alapján a TNBS által kiváltott vastagbélgyulladás során az egyik leginkább aktiválódott interakciós hálózat a TREM1 szignalizációs útvonal, míg a gyulladás- és tumor-gátló szerepéről ismert PPAR útvonal jó példája az inaktiválódott útvonalaknak a gyulladt területeken (10. táblázat).

Azt már a „core” analízis során megállapítottuk, hogy az immunsejtek aktiválásában, toborzásában, valamint a gyulladás folyamatában és a proinflammatorikus citokinek és kemokinek szabályozásában szerepet játszó útvonalak szignifikánsan megváltoztak a gyulladt szövetekben (9. táblázat). A z-érték figyelembe vételével azt is megállapítottuk, hogy ezen útvonalakat alkotó molekulák kifejeződésének iránya is egyértelműen tükrözi az aktív gyulladásra jellemző génexpressziós mintázatot (10. táblázat). A korábban említett IL6 és TREM1, továbbá a gyulladásos folyamatok szabályozásában szintén fontos Oncostatin M jelátvitel például jelentösen aktiválódott a gyulladt szövetekben, nemcsak a kontroll, hanem 
a nem-gyulladt mintákhoz képest is (10. táblázat). A komplement rendszer aktiválódását figyelhettük meg a gyulladt vs. kontroll összehasonlítás esetén, azonban a gyulladt vs. nemgyulladt minták között nem tapasztaltunk szignifikáns különbséget ennél az útvonalnál (10. táblázat). Ellenben az IL8 jelátvitel aktivitása jelentősen emelkedett a gyulladt vs. nemgyulladt összehasonlítás során, míg a gyulladt vs. kontroll esetben nem érte el a szignifikáns tartományt. Míg a gyulladt vs. kontroll összehasonlításban az aktiválódott és inaktiválódott kanonikus útvonalak egyensúlyban vannak, addig a gyulladt vs. nem-gyulladt összehasonlítás esetén az aktiválódott szignalizációs útvonalak túlsúlya figyelhető meg (10. táblázat). 
10. táblázat: A kanonikus szignalizációs útvonalak z-érték alapú besorolása. A kapcsolatok iránya és az abból adódó génexpresszió változás közötti korrelációt leíró z-érték $>2$ vagy $<-2$ teljesülése esetén tekinthető szignifikánsnak, melyet színskála jelöl: a piros a növekedés, a kék a csökkenést szimbolizálja, míg a szürke a nem-szignifikáns értékeket jelöli; ( $\mathrm{NaN}$ - a müvelet eredménye nem szám, nincs értelme).

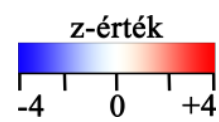

\begin{tabular}{|c|c|c|c|}
\hline Ingenuity Kanonikus Útvonalak & NGY-K z-érték & GY-K z-érték & GY-NGY z-érték \\
\hline Akut fázis reakció szabályozása & $\mathrm{NaN}$ & 4,02 & 4,27 \\
\hline TREM1 jelátvitel & $\mathrm{NaN}$ & 3,55 & 3,77 \\
\hline IL-6 jelátvitel & $\mathrm{NaN}$ & 2,75 & 3,78 \\
\hline Oncostatin M jelátvitel & $\mathrm{NaN}$ & 2,65 & 2,83 \\
\hline Fcy Receptor-mediated Phagocytosis in Macrophages and Monocytes & $\mathrm{NaN}$ & 2,40 & 3,13 \\
\hline Mintázatfelismerő receptorok szerepe a baktériumok és vírusok felismerésében & $\mathrm{NaN}$ & 2,36 & 2,24 \\
\hline Interferon jelátvitel & $\mathrm{NaN}$ & 2,24 & 1,41 \\
\hline PI3K/AKT jelátvitel & $\mathrm{NaN}$ & 2,18 & 1,89 \\
\hline Leukocita infiltráció jelátvitel & $\mathrm{NaN}$ & 2,16 & 3,77 \\
\hline Vastagbélrák metasztázis jelátvitel & $\mathrm{NaN}$ & 2,08 & 3,48 \\
\hline Komplement rendszer & $\mathrm{NaN}$ & 2,00 & $\mathrm{NaN}$ \\
\hline p38 MAPK jelátvitel & $\mathrm{NaN}$ & 1,96 & 2,45 \\
\hline Nitrogén-oxid és rekatív oxigén gyökök teremelése makrofágokban & $\mathrm{NaN}$ & 1,92 & 3,09 \\
\hline GM-CSF jelátvitel & $\mathrm{NaN}$ & 1,90 & 2,31 \\
\hline Hasnyálmirigy adenokarcinóma jelátvitel & $\mathrm{NaN}$ & 1,60 & 2,50 \\
\hline NFAT szerepe az immunválasz szabályozásában & $\mathrm{NaN}$ & 1,53 & 2,86 \\
\hline HMGB1 jelátvitel & $\mathrm{NaN}$ & 1,40 & 3,41 \\
\hline IL-8 jelátvitel & $\mathrm{NaN}$ & 1,22 & 3,18 \\
\hline Rac jelátvitel & $\mathrm{NaN}$ & 1,07 & 2,71 \\
\hline VEGF jelátvitel & $\mathrm{NaN}$ & 1,00 & 2,71 \\
\hline eNOS jelátvitel & $\mathrm{NaN}$ & 0,85 & 2,84 \\
\hline NANOG szerepe az emlős embrionális őssejt pluripotenciában & $\mathrm{NaN}$ & 0,82 & 2,00 \\
\hline Tec Kinase jelátvitel & $\mathrm{NaN}$ & 0,78 & 2,35 \\
\hline PKCO jelátvitel T limofcitákban & $\mathrm{NaN}$ & 0,73 & 2,32 \\
\hline PDGF jelátvitel & $\mathrm{NaN}$ & 0,58 & 2,71 \\
\hline iCOS-iCOSL jelátvitel Thelper sejtekben & $\mathrm{NaN}$ & 0,30 & 2,31 \\
\hline p53 jelátvitel & $\mathrm{NaN}$ & $-0,28$ & $-2,33$ \\
\hline PPAR $\alpha /$ RXR $\alpha$ aktiváció & $\mathrm{NaN}$ & $-1,15$ & $-2,13$ \\
\hline Hepatikus NK sejtek daganatellenes múködése & $\mathrm{NaN}$ & $-2,00$ & $\mathrm{NaN}$ \\
\hline Gaq jelátvitel & $\mathrm{NaN}$ & $-2,04$ & 0,43 \\
\hline Glioblastoma Multiforme jelátvitel & $\mathrm{NaN}$ & $-2,07$ & 0,50 \\
\hline Neuregulin jelátvitel & $\mathrm{NaN}$ & $-2,12$ & $-0,30$ \\
\hline CXCR4 jelátvitel & $\mathrm{NaN}$ & $-2,13$ & 0,24 \\
\hline Melatonin jelátvitel & $\mathrm{NaN}$ & $-2,33$ & $\mathrm{NaN}$ \\
\hline Neuropátiás fájdalom jelátvitel a hátulsó szarvi neuronokban & $-2,00$ & $-2,50$ & $\mathrm{NaN}$ \\
\hline Sperma motilitás & $\mathrm{NaN}$ & $-2,52$ & $-0,23$ \\
\hline LXR/RXR aktiváció & $\mathrm{NaN}$ & $-2,75$ & $-2,67$ \\
\hline PPAR jelátvitel & $\mathrm{NaN}$ & $-2,99$ & $-4,08$ \\
\hline Thrombin jelátvitel & $\mathrm{NaN}$ & $-3,27$ & $-0,82$ \\
\hline
\end{tabular}




\subsection{A gyulladásos válasz szabályozása a vastagbélgyulladás in vivo modelljében és IBD-s betegek vastagbelében}

\subsubsection{Mintázat felismerô receptorok aktiválódása a gyulladt vastagbélben}

A TNBS kezelés következtében a nyálkahártya integritása megszünik, így a bél lumenében kolonizáló baktériumok bejuthatnak a vastagbél szövetébe, továbbá a sérült és elpusztult sejtekből felszabaduló gyulladáskeltő anyagok immunválaszt indítanak el [114, 116]. A gyulladt szövetekben, mint a TNBS által kiváltott gyulladás esetén is, a mintázat felismerő receptorok (Pattern Recognition Receptors PRRs) molekuláris szenzorokként érzékelik a patogén eredetü PAMP-okat vagy a saját szövetekből származó veszély jeleket (DAMP). A mintázat felismerő receptorok által szabályozott jelátviteli útvonalak jelentősen aktiválódtak a TNBS kezelt állatok gyulladt területein (10. táblázat), ami összefügg a PRR családok (TLR és NLR; 9. ábra) és DAMP-ok (például S100a8, S100a9, függelék: F1. ábra) expressziójának szignifikáns változásával. A TLR családba jelenleg összesen 13 transzmembrán glikoprotein tartozik, melyek közül az emberben a TLR1-től a TLR10-ig jelölt PRR-ek találhatók; rágcsálókban további 3 (TLR11, -12 és -13) fordul elő. A sejttípusok széles skálája expresszálja őket, a mieloid-eredetü sejtektől kezdve az endotél- és epitélsejtekig [117]. A patkány vastagbélben kifejeződő TLR-ek közül 10-nek szignifikánsan megváltozott a kifejeződése a TNBS kezelést követően (9A. ábra). Aktiválódásuk NF-кB-n vagy IRF3 és IRF7-en (interferon regulatory factor 3/7) keresztül gyulladáskeltő citokinek termelését idézi elö [117].

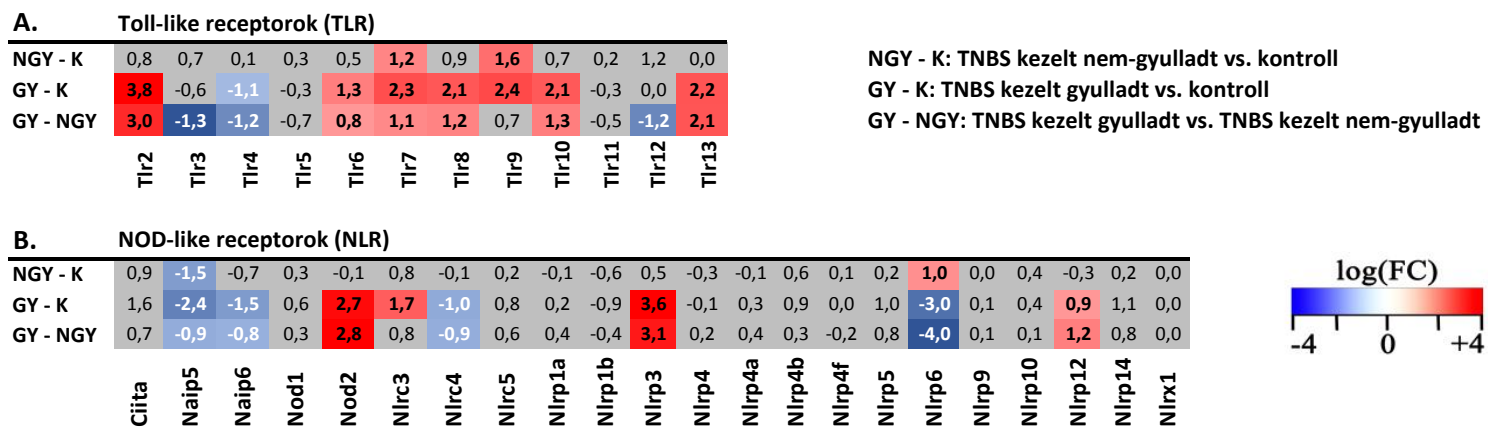

9. ábra: Mintázat felismerő receptorok kifejeződésének változása patkány vastagbélben TNBS kezelést követően. TLR (A) és NLR (B) receptor családok RNS-Seq által azonosított génexpressziós mintázata a nem-gyulladt vs. kontroll (NGY - K), gyulladt vs. kontroll (GY - K) és a gyulladt vs. nem-gyulladt (GY - NGY) minták összehasonlítása során. Az értékek logaritmikus skálán kifejezett fold change, azaz $\log (\mathrm{FC})$ értékek, a szignifikáns változás 
mértékét $>1$ vagy $<-1$ teljesülése esetén színskála jelöli, a piros a növekedés, a kék a génexpresszió csökkenést szimbolizálja; a szürke a nem-szignifikáns értékeket jelöli.

A PRR-ek másik nagy csoportjának, a citoplazmatikus NLR receptoroknak a kifejeződését csakúgy mint a TLR receptorokét - különbözőképpen befolyásolta a TNBS kezelés (9B. ábra). Az extra/intracelluláris vagy vezikulumokból származó exogén vagy endogén eredetü ligandok felismerését követően egyes NLR receptorok (pl.. NOD1/2) képesek aktiválni az NFkB vagy MAPK jelátvitelt, ami antimikrobiális fehérjék és gyulladáskeltő citokinek/kemokinek expresszióját indukálja; más NLR-ek inflammaszóma alkotóként a funkcióképes kaszpáz-1 létrehozásával citokinek (pl.: IL1 $\beta$ ) érését segíti elő, további NLRek pedig (pl.: NLRP6) negatívan szabályozzák a gyulladást [7]. Változatos funkciójuk változatos expressziós mintázattal társult: míg a Nod2, Nlrp3 és Nlrp12 expressziója szignifikánsan emelkedett, addig a Naip5, Naip6, Nlrc4 és Nlrp6 mRNS mennyisége csökkent a gyulladt területeken (9B. ábra).

Az RNS-Seq eredmények validálását független kvantitatív módszerrel is elvégeztük azért, hogy a minta előkészítésből, szekvenálásból illetve bioinfomatikai analízisből adódó esetleges fals eredményeket kiszürhessük. Ennek érdekében a dolgozatban megemlített számos gén kifejeződését követtük nyomon QPCR módszerrel is, majd az így mért expressziós változásokat összevetettük az RNS-Seq által azonosítottakkal. Annak érdekében, hogy megbizonyosodjunk, a felhasznált minták valóban tükrözik az irodalmi adatokat első körben olyan gének expresszióját vizsgáltuk meg, amelyek megváltozott kifejeződését már korábban összefüggésbe hozták a betegség patomechanizmusával (pl.: NOD2, NLRP3, TNFa, stb.), így ezek nem csupán az alkalmazott módszert (RNS-Seq), hanem a felhasznált biológiai minták hitelességét is igazolták.

A NOD2 receptor - ami a bakteriális sejtfalalkotó, MDP citoplazmatikus felismerését követően vált ki gyulladásos választ - mutációját elsőként azonosították, mint a Crohnbetegségre hajlamosító tényező [15]. A patkány vastagbél gyulladt területein mennyisége szignifikánsan megemelkedett, ellenben a TNBS kezelt nem-gyulladt szövetekben a kontroll mintákhoz képest változatlan maradt az expressziója (10A. ábra). A Nod2-vel azonos szignalizációs kaszkádot indukáló Nod1 (10B. ábra) az iE-DAP kötését követően aktiválja az immunválaszt, mennyisége azonban nem változott a TNBS kezelés hatására; míg a 
bakteriális eredetű flagellin felismerében szerepet játszó Naip6 (10C. ábra) expressziója egyaránt szignifikánsan csökkent a TNBS kezelt nem-gyulladt és gyulladt vastagbél területeken.

A.

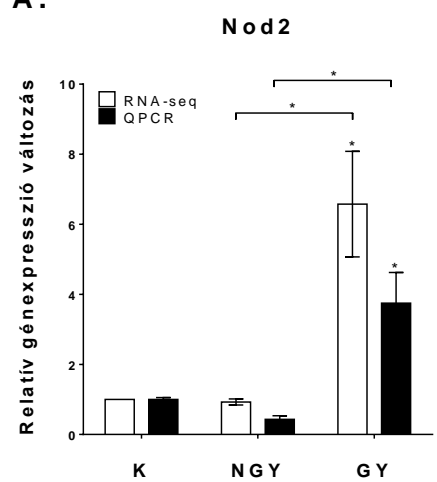

D.

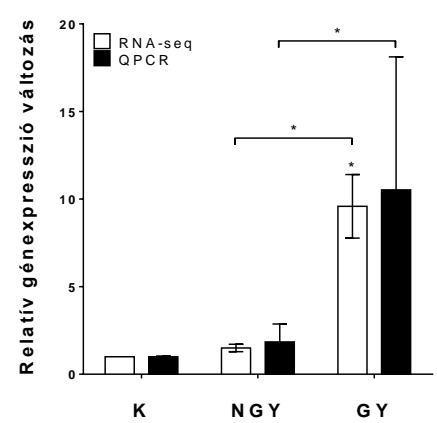

B.

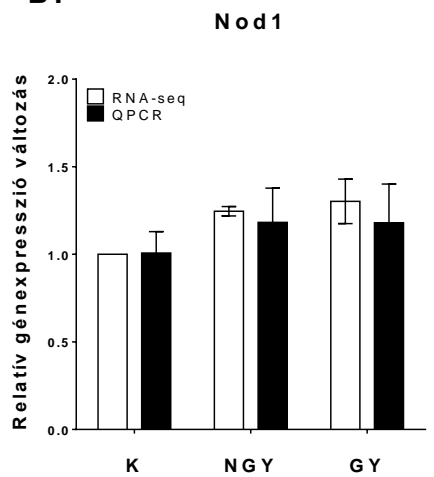

E.

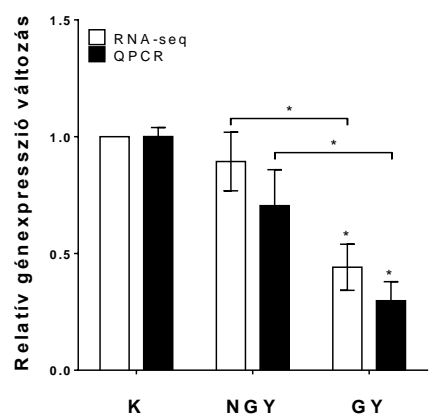

c.

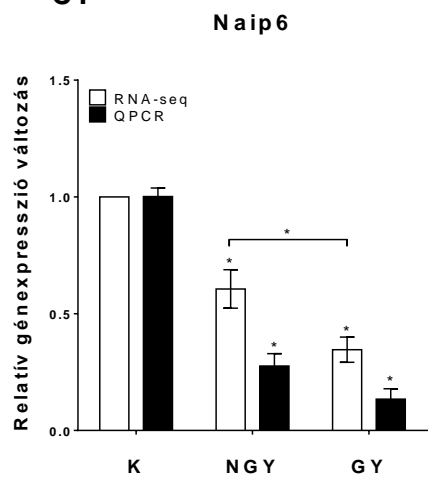

F.

$N \operatorname{Irp} 6$

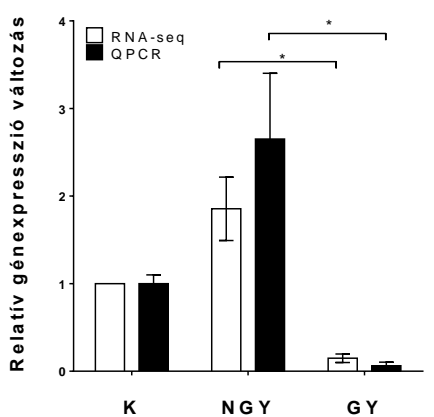

10. ábra: Az NLR receptorok génexpresszió változása a patkány vastagbélben a TNBS kezelést követően. A Nod2, Nod1, Naip6, Nlrp3, Nlrc4 és Nlrp6 (A-F) relatív génexpresszió változása a TNBS kezelt nem-gyulladt (NGY) és a TNBS kezelt gyulladt (GY) mintákban a kontroll (K) mintákhoz viszonyítva. A fehér oszlopok az RNS-Seq eredményeket, míg a fekete oszlopok a transzkriptóma analízis QPCR validálását mutatják $(*: \mathrm{p}<0,05)$.

Az inflammaszóma komplex kialakítására képes Nlrp3, Nlrc4 és Nlrp6 különbözö szubsztrátspecifitással rendelkeznek, ami megmagyarázza az inverz expressziós mintázatukat (10D-F. és 11. ábra). A komplex összeszerelődése elengedhetetlen az inaktív IL1 $\beta$, IL18 és IL33 citokinek későbbi kaszpáz-függő hasításához. Az NLRP3inflammaszóma az egyik legjobban jellemzett komplex, amely a korábban már említett, a gyulladt területeken szignifikánsan megemlkedett kifejeződésủ S100a8 és S100a9 (F1. ábra) DAMP-ok felismerése mellett, virális és bakteriális sejtalkotók által is aktiválódik [11, 118]. Az in vivo patkány IBD modellben, a szignifikánsan megemelkedett Nlrp3 kifejeződése 
(10D. ábra), egyidejü Il1 $\beta$ és Il33 mRNS növekedéssel társult (11. ábra). Ezzel szemben a gyulladásos válasz negatív regulátoraként ismert Nlrp6 és szubsztrátja, az Il18 [12, 13, 119] szintje csökkent a gyulladt területeken (10F. és 11. ábra). Az Nlrp6 transzkripcióját a antiinflammatórikus és anti-tumor aktivitásáról is ismert PPAR $\gamma$ transzkripciós faktor képes indukálni [83], melynek kifejeződése szintén szignifikánsan csökkent a TNBS kezelt állatok vastagbelének gyulladt régióiban (F1. ábra).

\begin{tabular}{|c|c|c|c|c|c|c|c|c|c|c|c|}
\hline NGY - K & 1,7 & 1,0 & 0,5 & 1,0 & $-0,3$ & $-0,1$ & 0,2 & 0,7 & $-0,1$ & $-0,8$ & $-0,9$ \\
\hline GY - K & 0,5 & $-0,6$ & 3,6 & $-3,0$ & 0,9 & $-1,0$ & 0,8 & 2,7 & 4,8 & $-1,7$ & 0,8 \\
\hline \multirow[t]{5}{*}{ GY - NGY } & $-1,3$ & $-1,5$ & 3,1 & $-4,0$ & 1,2 & $-0,9$ & 0,6 & 2,1 & 4,9 & $-0,9$ & 1,7 \\
\hline & Pycard & Casp1 & Nlrp3 & Nlrp6 & NIrp12 & NIrc4 & Nlrc5 & Aim2 & II1b & II18 & II33 \\
\hline & \multicolumn{8}{|c|}{ NGY - K: TNBS kezelt nem-gyulladt vs. kontroll } & \multicolumn{2}{|c|}{$\log (\mathrm{FC})$} & \\
\hline & \multicolumn{8}{|c|}{ GY - K: TNBS kezelt gyulladt vs. kontroll } & & & \\
\hline & \multicolumn{8}{|c|}{ GY - NGY: TNBS kezelt gyulladt vs. TNBS kezelt nem-gyulladt } & & & \\
\hline
\end{tabular}

11. ábra: Inflammaszóma alkotók és az általuk konvertált interleukinek expressziós mintázata TNBS indukált patkány vastagbélben. A nem-gyulladt vs. kontroll (NGY - K), gyulladt vs. kontroll (GY - K) és a gyulladt vs. nem-gyulladt (GY - NGY) minták összehasonlítása során az inflammaszóma komponesek és szusztrátjaik inverz expressziós mintázattal jellemezhetőek. A gyulladáskeltő Nlrp3 és szubsztrátja az IL1 $\beta$ és IL33 expressziója emelkedett, míg a gyulladásgátló Nlrp6 és szubsztárja, az I118 kifejeződése csökken. Az értékek logaritmikus skálán kifejezett fold change, azaz $\log (\mathrm{FC})$ értékek, a szignifikáns változás mértékét $>1$ vagy $<-1$ teljesülése esetén színskála jelöli, a piros a növekedés, a kék a génexpresszió csökkenést szimbolizálja; míg a szürke a nem-szignifikáns értékeket jelenti.

\subsubsection{A veleszületett immunitás sejtes komponenseinek toborzása}

A mintázat felismerő receptorok aktiválása molekuláris kaszkádot indít be, melynek célja az immunválasz effektorainak, az immunsejteknek a gyulladt területre történő toborzása. A sérült szövetek és a szervezet távolabbi pontjai közötti hatékony kommunikáció elsősorban kemotaktikus citokinek és kemokinek segítségével valósul meg. A gyulladás markereinek is tekinthető Tnf $\alpha$, Il1 $\beta, \mathrm{Il}, \mathrm{Ccl} 3$ és Cxcl1 kifejeződése jelentősen megemelkedett a léziós szövetekben (12A, B, D-F. ábra), ami egyértelmü bizonyítéka a fennálló gyulladásnak: hatásukra agranulociták és granulociták infiltrálnak a vérből a szövetekbe. Fontos megjegyezni, hogy a TNBS kezelt patkányok makroszkópikusan nemgyulladtként jellemezett vastagbél területein nem tapasztaltunk génexpressziós változást ezen markerek expressziójában (12. ábra). 
Az anti-inflammatórikus IL10 szerepe a gyulladás szabályozásában vitathatatlan: gyulladás-gátló citokinként részt vesz a szöveti homeosztázis fenntartásában és helyreállításában, továbbá kontrollálja az immunsejtek aktiválódást mikrobiális fertőzések esetén [120, 121]. A TNBS által kiváltott vastagbélgyulladás esetén kifejeződése szignifikánsan emelkedett a gyulladt régiókban, ellenben a nem-gyulladt területeken változatlan maradt az expressziója (12C. ábra).

A.

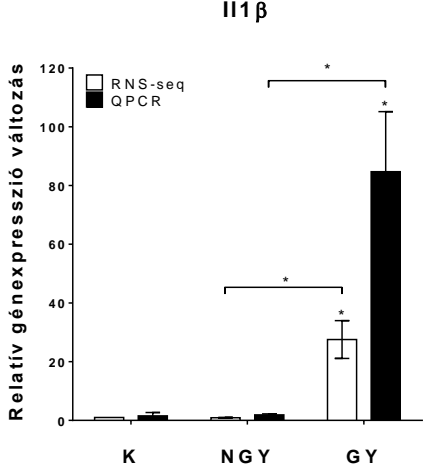

D.

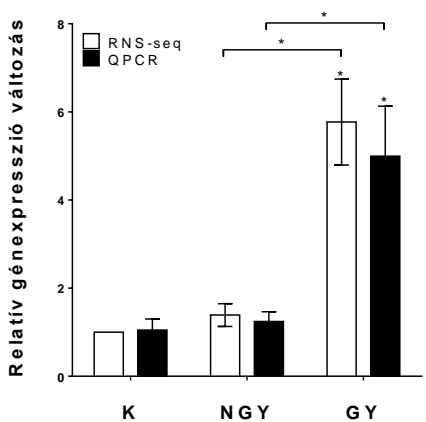

B.

116

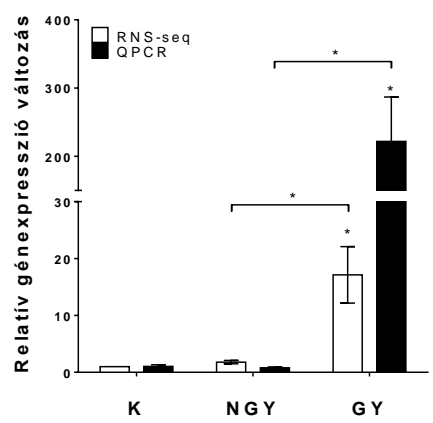

E.

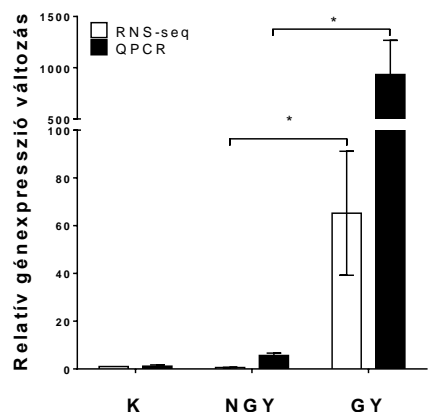

C.

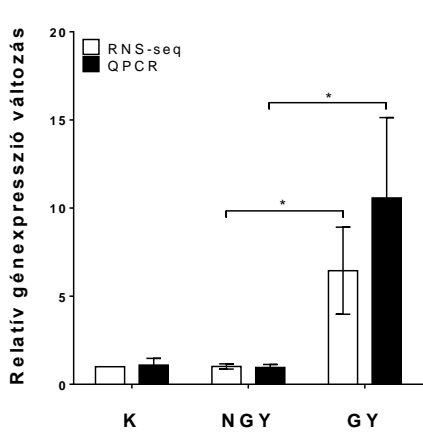

F.

Cxcl1

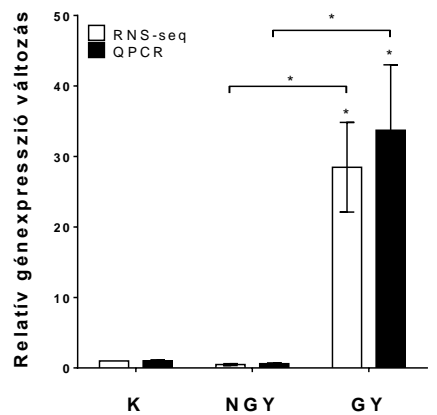

12. ábra: A gyulladáskeltő citokinek és kemokinek a megemelkedett expressziója TNBS kezelés hatására patkány vastagbélben. $\mathrm{Az} \mathrm{I} 11 \beta, \mathrm{Il}, \mathrm{Il10}, \mathrm{TNF} \alpha, \mathrm{Ccl} 3$ és $\mathrm{Cxcl1}$ (A-F) relatív génexpresszió változása a TNBS kezelt nem-gyulladt (NGY) és a TNBS kezelt gyulladt (GY) mintákban a kontroll (K) mintákhoz viszonyítva. A fehér oszlopok az RNSSeq eredményeket, míg a fekete oszlopok a transzkriptóma analízis QPCR validálását mutatják $(*: \mathrm{p}<0,05)$.

Az IBD-s páciensekből izolált minták vizsgálata során a TNF $\alpha$, IL1 $\alpha$ és IL6 citokineket pozitív kontrollként alkalmaztuk az aktív gyulladás fennállásának igazolására. Mindhárom általunk vizsgált gyulladáskeltő citokin emelkedett kifejeződését azonosítottuk az aktív-gyulladt csoportban, mind az inaktív mind az aktív-nem gyulladt csoporthoz viszonyítva (13. ábra); következésképpen a relapszáló IBD-s betegek sérült 
vastagbélrégióiban zajló, makroszkópikusan is megfigyelhető gyulladásos folyamatokat molekuláris szinten is igazoltuk.
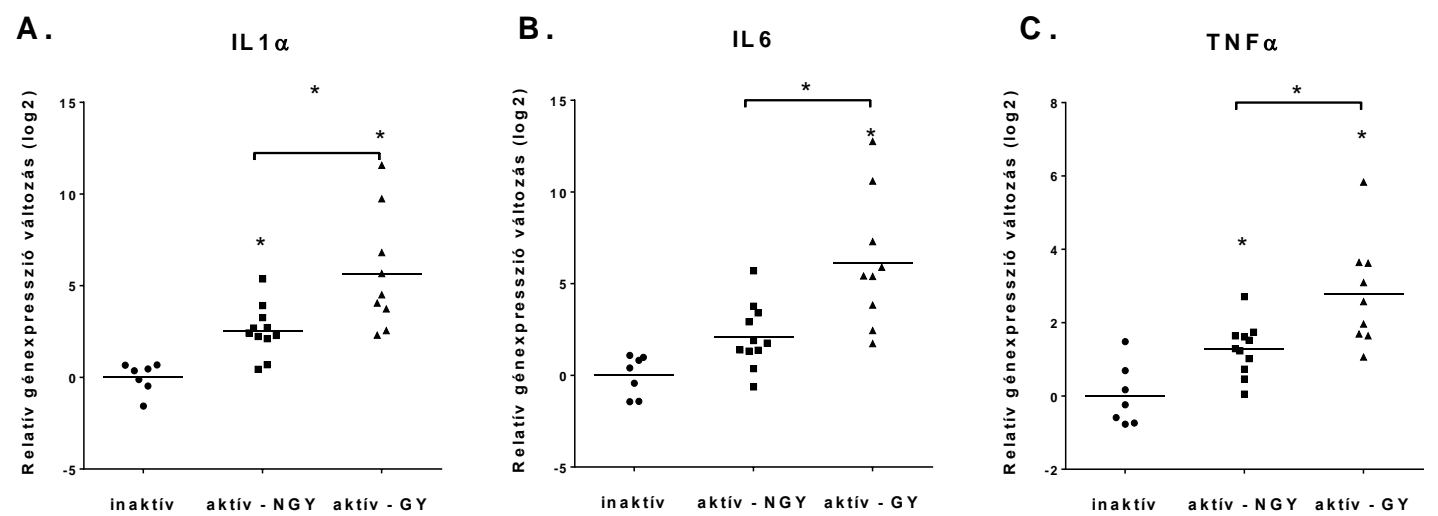

13. ábra: Gyulladásos citokinek kifejeződésének változása IBD-s betegekben. Az IL1 $\alpha$, IL6 és TNF $\alpha$ (A-C) relatív génexpresszió változása az aktív nem-gyulladt (NGY) és az aktív - gyulladt (GY) mintákban az inaktív humán mintákhoz viszonyítva. A körök, négyzetek és háromszögek egyedi értékeket, míg a vízszintes vonalak, azok átlagát ábrázolják (*: $\mathrm{p}$ < $0,05)$.

\subsubsection{Az immunválasz negatív szabályozása}

A gyulladásos válasz során a sérült sejtekből felszabaduló DAMP-ok (pl.: S100a8, S100a9) felismerését követően aktiválódó jelátviteli kaszkád, az egész szervezetre kiterjedő választ generál, ami öngerjesztő folyamatként robosztus módon nyilvánul meg. Annak érdekében, hogy ez a reakció ne váljon irányíthatatlanná és a saját szervekre, szövetekre károssá, szükségesek negatívan szabályozó, a gyulladást gátló visszacsatolások.

A TLR-ek által kiváltott gyulladás negatív regulátorai - többek között - a TAM receptorok. Ezek a tirozin-kináz receptorok a ligand kötését követően SOCS1 és SOCS3 antiinflammatórikus gének kifejeződését indukálják, melyek a citokinek és mikrobiális ligandok által aktivált JAK-STAT és a TLR jelátviteli útvonalban kulcsfontosságú fehérjék degradálását idézik elő [122]. A TNBS kezelt patkány vastagbelekben a TAM receptorok és ligandjaik különböző irányú génexpressziós változását állapítottuk meg (14. ábra). Míg az Axl kifejeződése szignifikánsan megemelkedett mind mRNS (14B. ábra) mind fehérje (15. ábra) szinten a gyulladt bélszakaszokban, addig a Mertk (14C. ábra) expressziója enyhén, de nem szignifikánsan, a Tyro3 (14A. ábra) szintje pedig szignifikánsan csökkent. Ligandjaik 
közül a Gas6 (14D. ábra) génexpressziója nem változott a TNBS kezelés hatására, míg a Pros1 (14E. ábra) kifejeződése szignifikánsan megemelkedett a gyulladás helyén.

A.

Tyro3

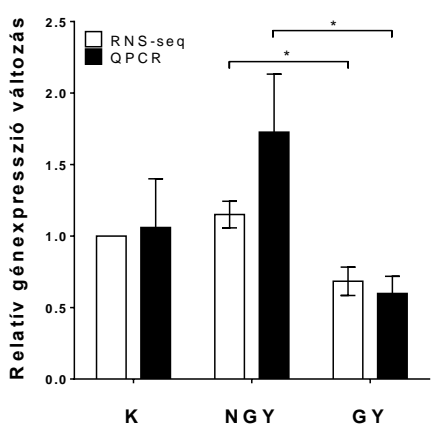

D.

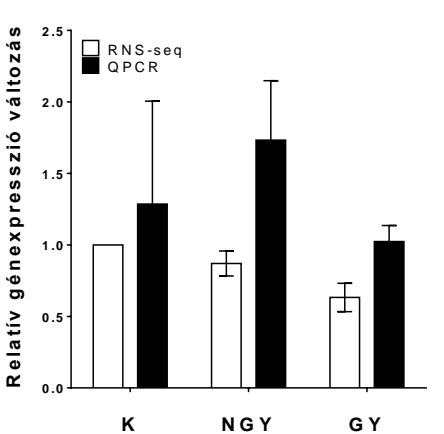

A XI

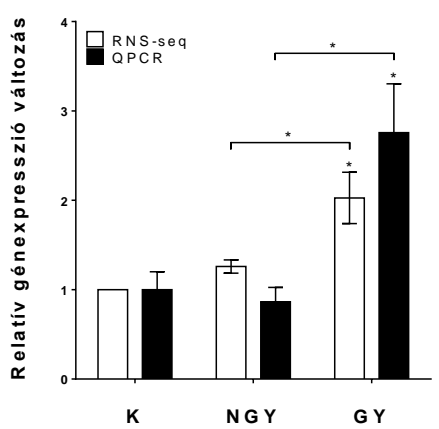

E.
C.

Mertk

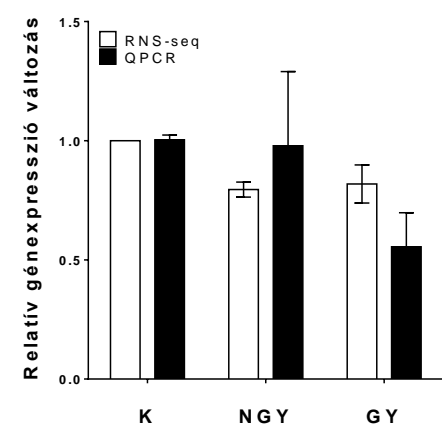

Pros 1

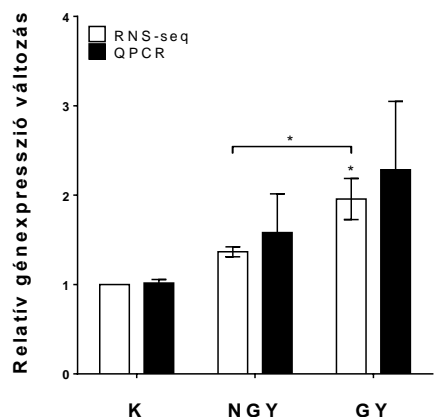

14. ábra: TAM receptorok és ligandjaik expressziója a patkány vastagbélben. Az Tyro3, Axl, Mertk, Gas6 és Pros1 (A-E) relatív génexpresszió változása a TNBS kezelt nem-gyulladt (NGY) és a TNBS kezelt gyulladt (GY) mintákban a kontroll (K) mintákhoz viszonyítva. A fehér oszlopok az RNS-Seq eredményeket, míg a fekete oszlopok a transzkriptóma analízis QPCR validálását mutatják (*: $\mathrm{p}<0,05)$.

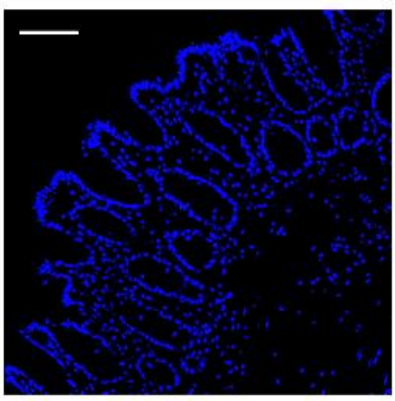

kontroll

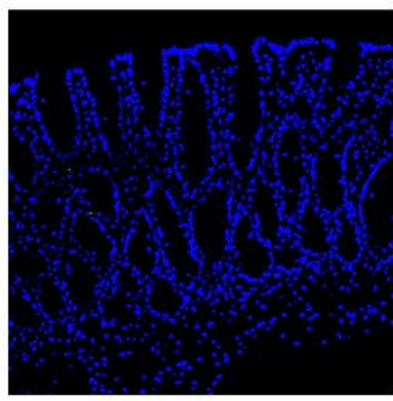

nem-gyulladt

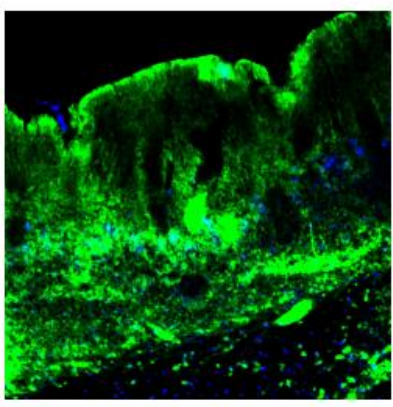

gyulladt

15. ábra: Axl fehérje mennyiségének változása a patkány vastagbélben a kísérletesen kiváltott vastagbélgyulladás során. $\mathrm{Az} \mathrm{Axl}$ fehérje kifejeződésének immunfluoreszcens 
vizsgálata a kontroll, a TNBS kezelt nem-gyulladt és a TNBS kezelt gyulladt patkány vastagbél metszetekben (kék - DAPI: sejtmag, zöld - FITC: Axl; skála: $100 \mu \mathrm{m}$ ).

Az IBD-s betegekből származó izolátumok esetén csak az AXL (16B. ábra) kifejeződésében mértünk szignifikáns génexpressiós változást, a TYRO3 (16A. ábra) és MERTK (16C. ábra) mRNS mennyisége változatlan maradt az IBD-s betegek vastagbelében.
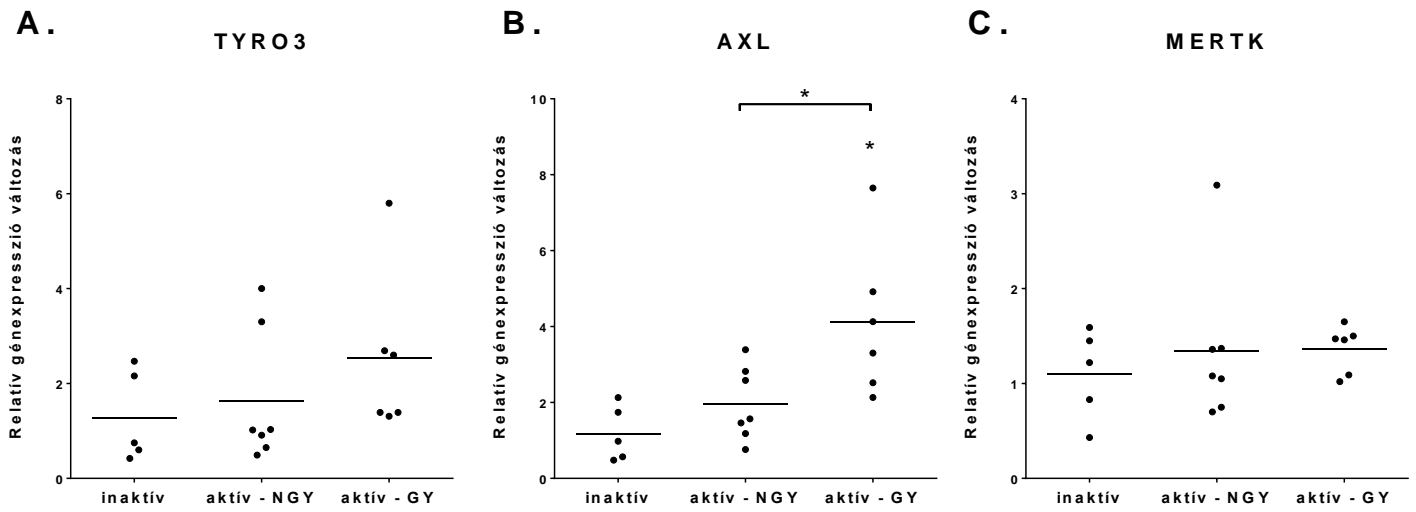

16. ábra: TAM receptorok kifejeződése az IBD-s betegek vastagbelében. A TYRO3, AXL és MERTK (A-C) relatív génexpresszió változása az aktív nem-gyulladt (NGY) és az aktív gyulladt (GY) mintákban az inaktív humán mintákhoz viszonyítva. A körök egyedi értékeket, míg a vízszintes vonalak, azok átlagát mutatják $(*: \mathrm{p}<0,05)$.

\subsubsection{A nyálkahártya védelme}

A nyálkahártya integritásának megőrzésében és a béltraktusban kolonizáló baktériumok féken tartásában jelentős szereppel bírnak az epitélsejtek felszínét beborító nyákréteget kialakító mucinok és a glikokalixot létrehozó glikoziltranszferázok. A transzkriptóma vizsgálat során azt tapasztaltuk, hogy habár a kontroll és TNBS kezelt nemgyulladt minták nagyon hasonlóak transzkripcionális szinten (7. ábra), azonban ha a nyálkahártya védelméért felelős mucinok és azok glikolizációjában szerepet játszó fehérjéket kódoló gének expresszióját követtük nyomon, jelentős különbséget figyelhettünk meg közöttük (lásd 17. - 19. és 20. ábra). Míg a membrán-kötött mucin formák kifejeződése csökkent a gyulladt területeken, és nem változott jelentősebben a nem-gyulladt régiókban, addig a gél-formáló Muc2 és Muc5b expressziója szignifikánsan nőtt a TNBS kezelt vastagbelek intakt azaz nem-gyulladt szakaszaiban (17. ábra). 


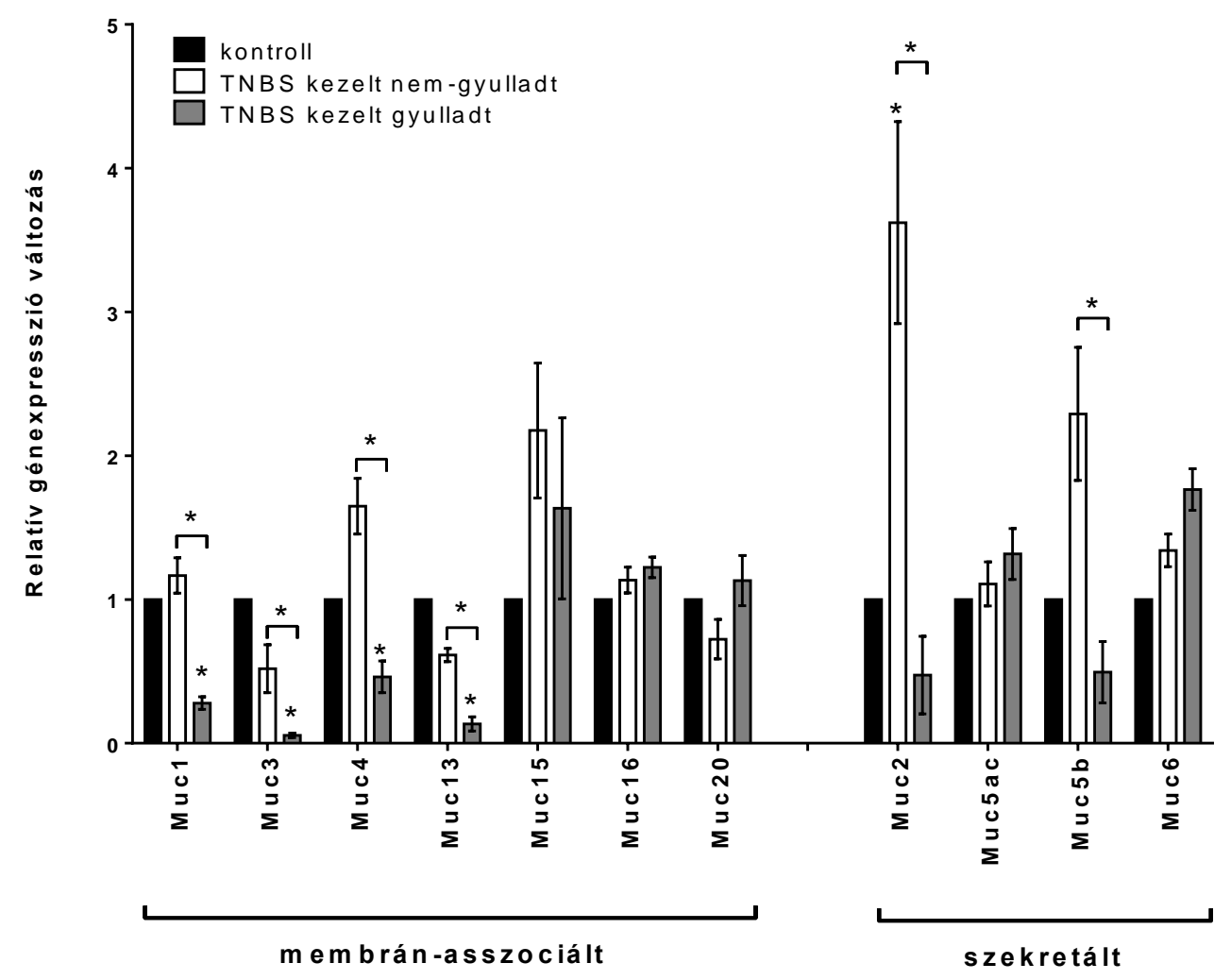

17. ábra: Mucinok génexpressziója TNBS kezelt patkány vastagbélben. A membránasszociált és szekretált mucinok kifejeződésének változása a TNBS kezelt nem-gyulladt (fehér) és a TNBS kezelt gyulladt (szürke) mintákban a kontroll (fekete) mintákhoz viszonyítva az RNS-Seq analízis alapján $(*: \mathrm{p}<0,05)$.

Az erősen glikolizált MUC2 fehérje polimerizációjával létrejövő kettős nyákréteg távol tartja a bélben élő kommenzalista és patogén baktériumokat a nyálkahártyától, ezzel védve az IEC sejteket a PAMP-ok által aktivált gyulladástól. A Muc2 expressziójának emelkedése a TNBS kezelt patkány vastagbél ép területein fokozott védelmet jelenthet a további szöveti károsodással szemben (18A. ábra).

Korábban arról számoltak be, hogy a gyulladásos bélbetegségben szenvedők vastagbelében a MUC2 mennyisége - a páciensek közötti egyéni változékonyság miatt - nem tér el jelentősen a kontroll és beteg csoportok között; azonban a vizsgálat során a relapszáló betegek vastagbél területeiből páciensenként csak egyetlen biopsziát készítettek [40]. Ahogy azt az általunk bemutatott gének kifejeződését vizsgálva is láttuk, a vastagbél gyulladt és nem-gyulladt szövetrégióinak génexpressziós mintázata között sok esetben szignifikáns 
eltérés tapasztalható, igaz ez az in vivo patkány modell, illetve az IBD-s betegekből izolált minták esetén is.

Kísérleteink során megállapítottuk, hogy az IBD-s páciensekből származó biopsziákban a MUC2 gén kifejeződése az aktív stádiumban lévő IBD-s betegek nemgyulladt és gyulladt vastagbél területein - a patkány vastagbélhez hasonlóan - eltérő: a makroszkópikusan normális területeken magasabb mint a fekélyes részeken (18A., B. ábra). Habár a humán betegekből származó mintákon az eltérés nem szignifikáns, ez valószínüleg az alacsony mintaszámnak köszönhető, ami miatt a páciensekre jellemző egyéni expressziós értékek nagyobb szórást eredményezhetnek.

A.

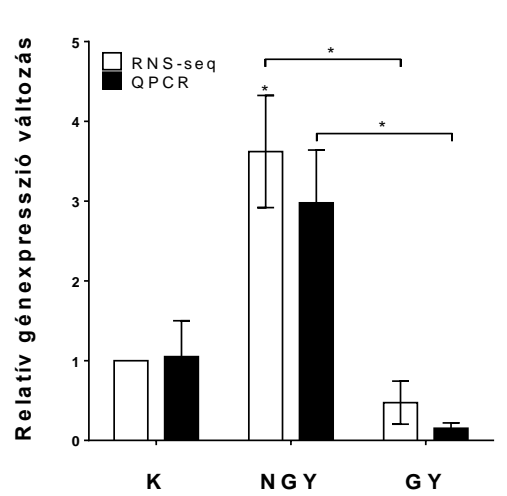

C.

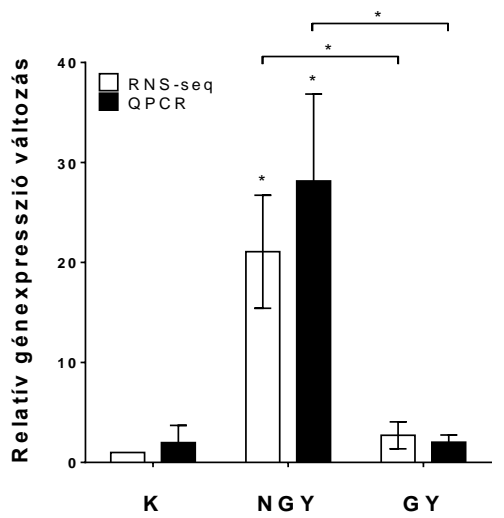

B.

M U C 2

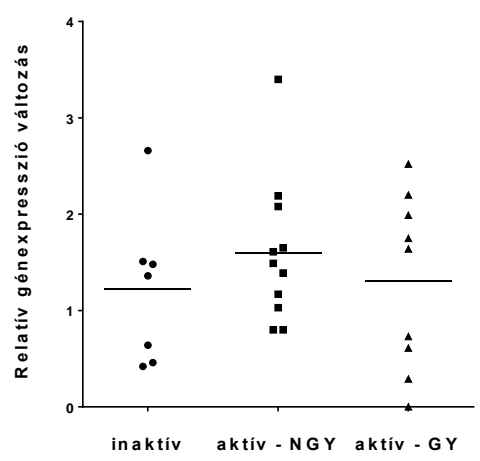

D.

A $4 \mathrm{gnt}$

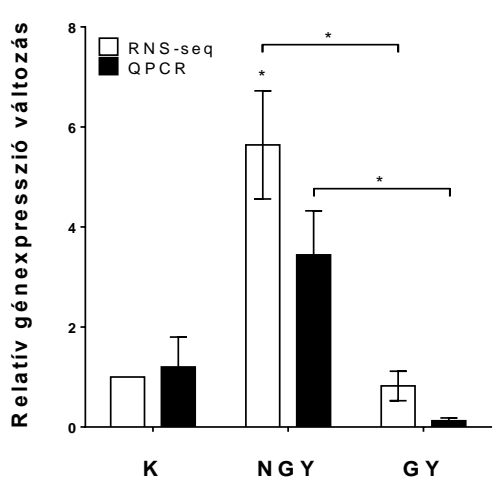

18. ábra: A nyálkahártya védelmében szerepet játszó molekulák kifejeződésének változása vastagbélgyulladás során. Az Muc2 (A), Dmbt1 (C) és az A4gnt (D) relatív génexpresszió változása a TNBS kezelt nem-gyulladt (NGY) és a TNBS kezelt gyulladt (GY) mintákban a kontroll (K) mintákhoz viszonyítva. A fehér oszlopok az RNS-Seq eredményeket, míg a fekete oszlopok a transzkriptóma analízis QPCR validálását mutatják. A MUC2 (B) relatív génexpresszió változása az aktív - nem-gyulladt (NGY) és az aktív - 
gyulladt (GY) mintákban az inaktív humán mintákhoz viszonyítva. A pontok egyedi értékeket, míg a vízszintes vonalak, azok átlagát mutatják $(*: \mathrm{p}<0,05)$.

A klasszikus mucinok mellett, a mucin-szerü fehérjék közé sorolt DMBT1 (deleted in malignant brain tumors 1) kifejeződése is szignifikánsan megemelkedett a TNBS-kezelt nem-gyulladt területeken, ellenben a gyulladt régiókban változatlan maradt a mennyisége (18C. ábra). Korábbi tanulmányok szerint a DMBT1 egy önszabályozó visszacsatoláson keresztül képes a NOD2 és a TLR4 gátlására, így a gyulladásos válasz enyhítésére [123].

A transzkriptóma vizsgálat során detektált több mint 30 glikoziltranszferáz többségének jelentősen változott az expressziója a vastagbél különböző részein (19. ábra). Közülük az $\alpha 1,4-\mathrm{N}$-acetilglükózamin transzferáz (A4GNT) is felelős a mucinokra jellemző glikolizációs mintázat kialakításáért [124]. Expressziója a Muc2 és Dmbt1 génekhez hasonlóan szignifikánsan nőtt a TNBS kezelt nem-gyulladt mintákban (18D. és 19. ábra).

A glikoziltranszferázok közé tartozó humán B4GALNT2 fehérje csökkent kifejeződését figyelték meg vastagbélrákban, ami az általa gátolt $\mathrm{sL}^{\mathrm{X}}$ antigén emelkedett kifejeződésével és fokozott metasztázis formációval járt $[125,126]$. A TNBS indukált patkány IBD modellben a B4galnt2 kifejeződésében szignifikáns különbséget azonosítottunk: mennyisége a nem-gyulladt vastagbél területeken megemelkedett, míg a gyulladt régiókban a kontroll mintákhoz képest változatlan maradt, azonban a TNBS kezelt nem-gyulladt szövetekhez képest szignifikánsan csökkent (19. ábra).

\begin{tabular}{|c|c|c|c|c|c|c|c|c|c|c|c|c|c|c|c|c|c|c|c|}
\hline \multirow[b]{2}{*}{ NGY - K } & \multicolumn{19}{|c|}{ Glikoziltranszferázok } \\
\hline & 2,5 & 2,2 & 1,8 & 1,7 & $-0,5$ & $-0,1$ & 0,7 & 0,9 & 1,0 & $-0,1$ & $-0,1$ & 0,4 & $-1,2$ & $-1,2$ & 0,4 & 0,3 & 0,7 & 0,5 & 0,1 \\
\hline GY - K & $-0,3$ & $-0,2$ & 1,1 & $-0,7$ & $-1,9$ & $-1,2$ & $-1,3$ & $-1,0$ & 0,0 & $-2,1$ & $-1,1$ & $-1,4$ & $-1,8$ & $-2,1$ & 1,7 & 1,7 & 1,5 & 1,0 & 1,1 \\
\hline I - NGY & $-2,8$ & $-2,4$ & $-0,7$ & $-2,4$ & $-1,4$ & $-1,2$ & $-2,0$ & $-1,9$ & $-1,0$ & $-2,0$ & $-1,0$ & $-1,7$ & $-0,5$ & $-0,9$ & 1,2 & 1,5 & 0,9 & 0,5 & 1,0 \\
\hline & $\begin{array}{l}\stackrel{艹}{5} \\
\stackrel{0}{\&}\end{array}$ & 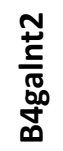 & 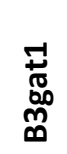 & 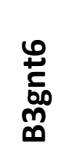 & 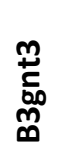 & 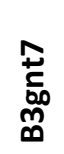 & 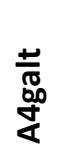 & $\begin{array}{l}\mathbb{N} \\
\frac{N}{\mathbb{D}} \\
\ddot{M} \\
0\end{array}$ & 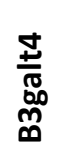 & 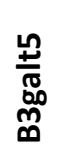 & 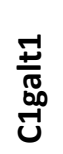 & 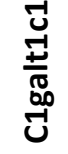 & 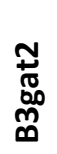 & $\underset{\substack{\tilde{D} \\
\tilde{D}}}{\stackrel{N}{\sim}}$ & $\begin{array}{l}\bar{\Phi} \\
\frac{\pi}{\pi} \\
\ddot{m} \\
\infty\end{array}$ & 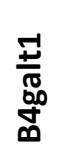 & $\begin{array}{l}\frac{5}{\pi} \\
\frac{00}{0} \\
\end{array}$ & 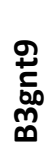 & 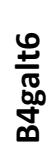 \\
\hline
\end{tabular}

NGY - K: TNBS kezelt nem-gyulladt vs. kontroll

GY - K: TNBS kezelt gyulladt vs. kontroll

GY - NGY: TNBS kezelt gyulladt vs. TNBS kezelt nem-gyulladt

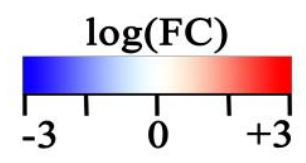

19. ábra: A glikoziltranszferázok kifejeződésének változatos mintázata a TNBS által kiváltott patkány vastagbélgyulladásban. Glikoziltranszferázok génexpressziós mintázata a nem-gyulladt vs. kontroll (NGY - K), gyulladt vs. kontroll (GY - K) és a gyulladt vs. nemgyulladt (GY - NGY) patkány minták összehasonlítása során. Az értékek logaritmikus skálán 
kifejezett fold change, azaz $\log (\mathrm{FC})$ értékek, a szignifikáns változás mértékét $>1$ vagy $<-1$ teljesülése esetén színskála jelöli, a piros a növekedés, a kék a génexpresszió csökkenést szimbolizálja; míg a szürke a nem-szignifikáns értékeket jelenti.

A glikoziltranszferáz szupercsaládba tartozó fukoziltranszferázok fukóz származékok transzferét katalizálják különféle akceptor molekulákhoz: például oligoszacharidokhoz, glikoproteinekhez és glikolipidekhez [24]. Közülük a Fut1, Fut2, Fut4 és Fut9 (20. ábra) kifejeződése szignifikánsan változott a TNBS kezelést követően a patkány vastagbélben. Az $\alpha 1,2-F U T$ alcsaládhoz tartozó FUT1 és FUT2 felelősek az bél epitéliumot alkotó sejtek fukozilálásáért [127]. A TNBS kezelést követően a patkány vastagbél gyulladt területein szignifikánsan csökkent Fut1 (20A. ábra) és Fut2 (20B. ábra) kifejeződés az általuk szintetizált szénhidrát alegységek elégtelen vagy hibás konformációját eredményezheti, ezáltal csökken az epitélsejteket védő fizikai barrier hatékonysága.

A.

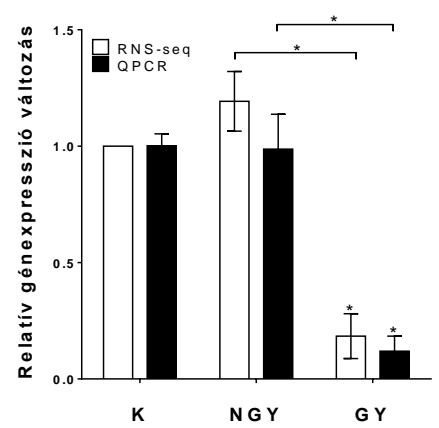

C.

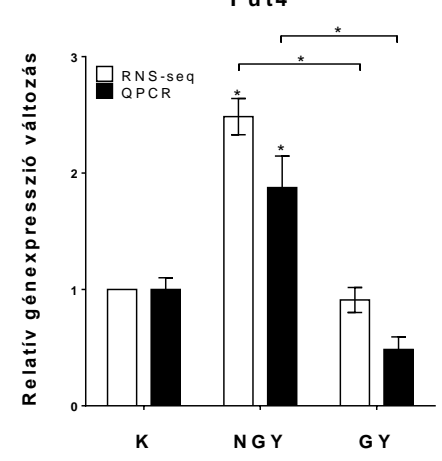

B.

Fut2

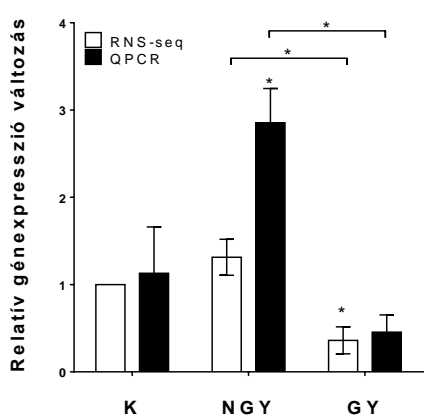

D.

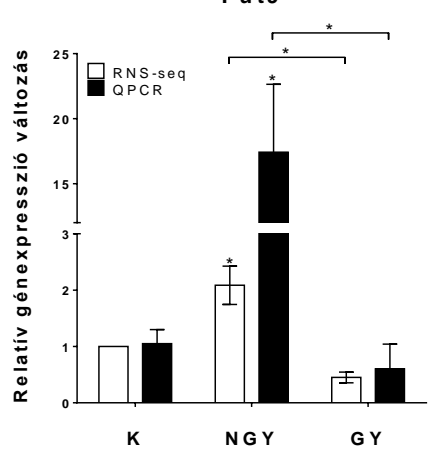

20. ábra: A fukoziltranszferázok génexpressziós mintázata a patkány vastagbélben. A Fut1, Fut2, Fut4 és Fut9 (A-D) relatív génexpresszió változása a TNBS kezelt nem-gyulladt (NGY) és a TNBS kezelt gyulladt (GY) patkány vastagbél mintákban a kontroll (K) mintákhoz viszonyítva. A fehér oszlopok az RNS-Seq eredményeket, míg a fekete oszlopok a transzkriptóma analízis QPCR validálását mutatják $(*$ : $\mathrm{p}<0,05)$. 
Az $\alpha 1,3 / 4-$ FUT-ok közé tartozó Fut4 (20C. ábra) és Fut9 (20D. ábra) FUT-okra a Fut1/2-től eltérő expressziós mintázat jellemző: mRNS mennyiségük szignifikánsan nőtt a TNBS kezelt patkány vastagbelek nem-gyulladt területein a kontroll mintákhoz viszonyítva; ellenben a gyulladt területeken nem változott szignifikánsan a kifejeződésük. Az $\alpha 1,3 / 4-$ FUT-ok a szénhidrát láncok szintézisének eltérő lépéseiért felelősek, mint a $\alpha 1,2-F U T$ : feltételezésünk szerint ez is lehet az oka annak, hogy az expressziós mintázatuk különböző a gyulladás során. A FUT4 felelős például az $\mathrm{Le}^{\mathrm{Y}}$ antigén szintéziséért, melynek fokozott kifejeződése jellemzi az epitéliális eredetű daganatsejteket [128], ahol a FUT4 az NF-кB jelátvitel közvetett aktiválásával, az EMT-t indukáló SNAI1 kifejeződését idézi elő [129]. 


\subsection{Az epiteliális-mezenhimális átmenet aktiválása a gyulladt szövetekben}

A TNBS indukált vastagbélgyulladás in vivo patkány modelljének transzkriptóma vizsgálata során eltérő expressziós mintázatot mutató molekulák közötti kapcsolatok felderítésére végzett funkcionális analízis során a gyulladás folyamatát több szinten szabályozó szignalizációs útvonalak aktiválódását azonosítottuk (9. és 10. táblázat). Vizsgálataink során számos közös pontot, szabályozó molekulát azonosítottunk, melyek szerepe nemcsak a gyulladás féken tartásában és a szöveti homeosztázis helyreállitásában, hanem a daganatos elváltozások kialakulásában is ismert. A két folyamatot legmarkánsabban összekapcsoló jelenség az epiteliális-mezenhimális tranzíció, melynek molekuláris komponensei szignifikásan aktiválódtak a TNBS által kiváltott vastagbélgyulladás esetén (21.-23. ábrák). Ismert, hogy a mezenhimális fenotípus kialakításáért felelős útvonalak aktivációját növekedési faktorok, többek között Fgf2 (21A. ábra), Fgf7 (21B. ábra) és Egr1 (21C. ábra) indukálják, melyek szignifikánsan megemelkedett kifejeződését azonosítottuk a vastagbél gyulladt területein.
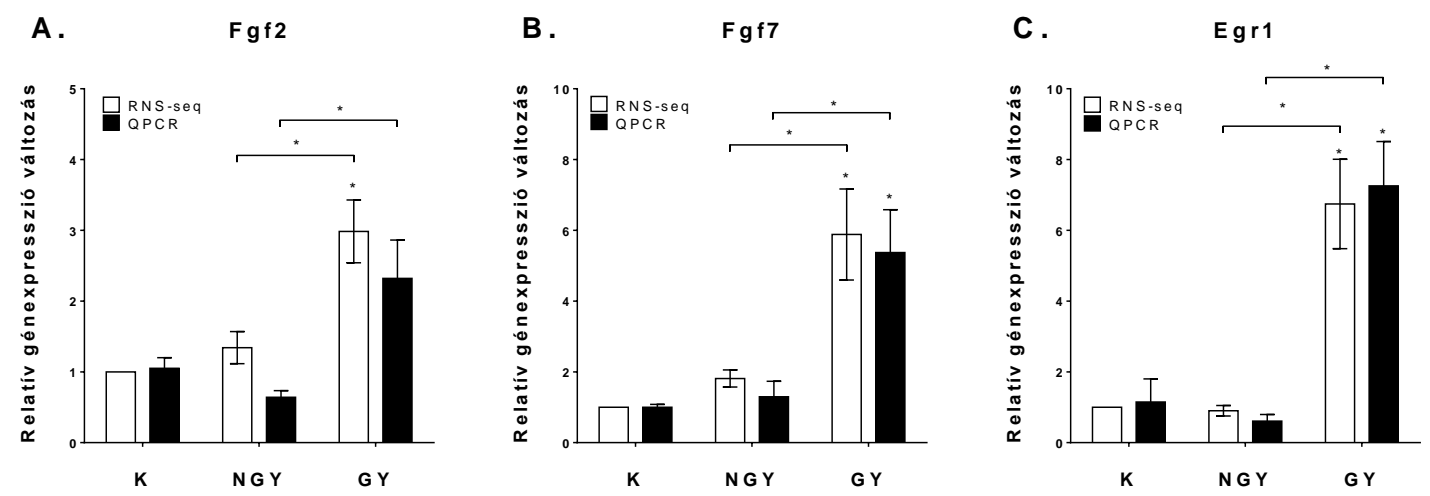

21. ábra: Az EMT aktiválása növekedési faktorok által a patkány gyulladt vastagbélben. Az Fgf2, Fgf7 és Egr1 (A-C) relatív génexpresszió változása a TNBS kezelt nem-gyulladt (NGY) és a TNBS kezelt gyulladt (GY) patkány vastagbél mintákban a kontroll (K) mintákhoz viszonyítva. A fehér oszlopok az RNS-Seq eredményeket, míg a fekete oszlopok a transzkriptóma analízis QPCR validálását mutatják (*: $\mathrm{p}<0,05)$. 
Ezzel párhuzamosan, a JAK/STAT és NOTCH szignalizációban résztvevő fehérjéket kódoló gének, a Notch1 (22A. ábra), a Notch2 (22B. ábra) és a Jak2 (22C. ábra), továbbá az oxigénmentes körülmények hatására aktiválódó Hifla (22D. ábra) expressziója is szignifikánsan megemelkedett a gyulladt területeken.

A.

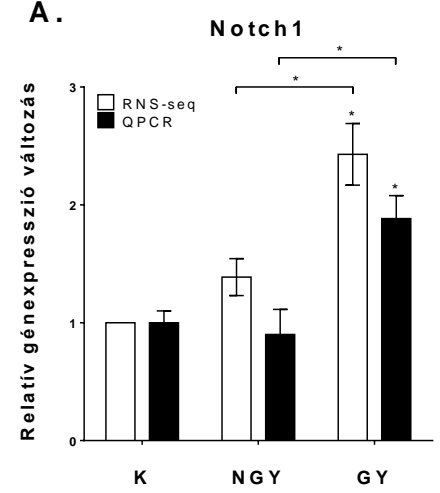

c.

Jak 2

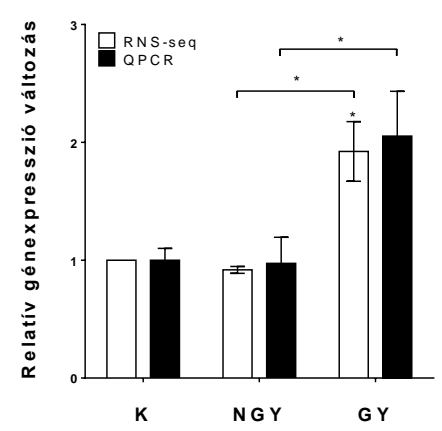

B.

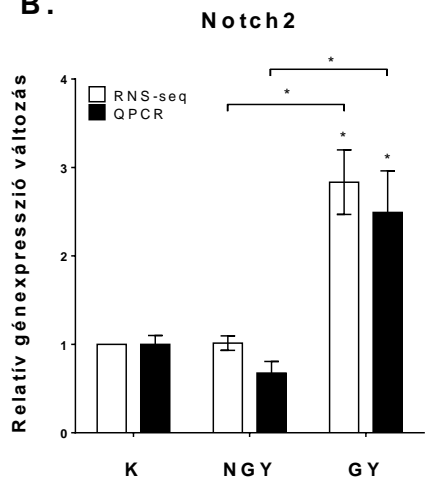

D.

$H$ if $1 \alpha$

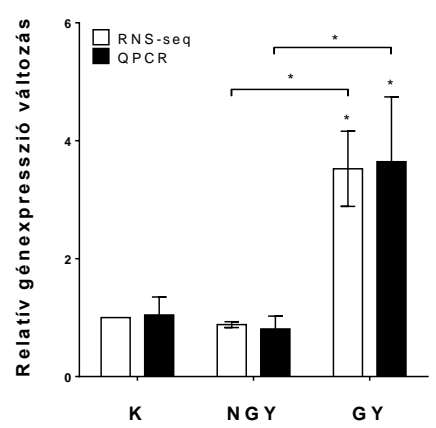

22. ábra: Az EMT-ben fontos szereppel bíró szignalizációs útvonalak aktiválása a patkány vastagbélgyulladás során. A Notch1, Notch2, Jak2 és Hif1 $\alpha$ (A-D) relatív génexpresszió változása a TNBS kezelt nem-gyulladt (NGY) és a TNBS kezelt gyulladt (GY) patkány vastagbél mintákban a kontroll $(\mathrm{K})$ mintákhoz viszonyítva. A fehér oszlopok az RNS-Seq eredményeket, míg a fekete oszlopok a transzkriptóma analízis QPCR validálását mutatják $(*: p<0,05)$.

Az EMT-t indukáló transzkripciós faktorok, mint pl. a Zeb2 (23A. ábra) és a Snai1 (23B. ábra) szignifikánsan megemelkedett szintjével összhangban megemelkedett a mezenhimális markerek, pl. az Mmp9 (23D. ábra), a Lox (23E. ábra) és a Vim (23F. ábra) mRNS mennyisége; ezzel szemben az epiteliális fenotípusra jellemző Cdh1 kifejeződése szignifikánsan csökkent (23C. ábra). 
A.

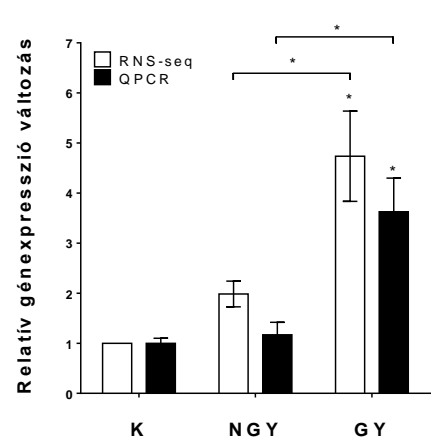

D.

$M m p 9$

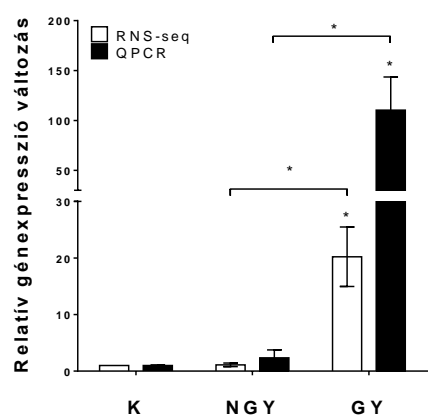

B.

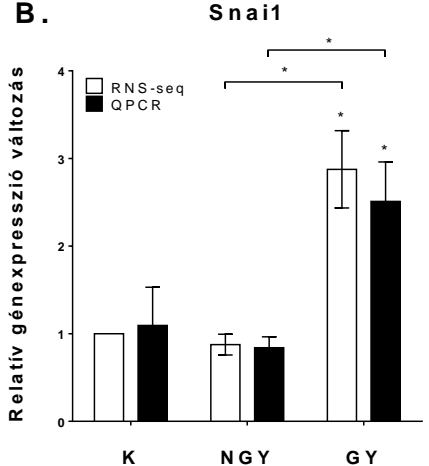

E.

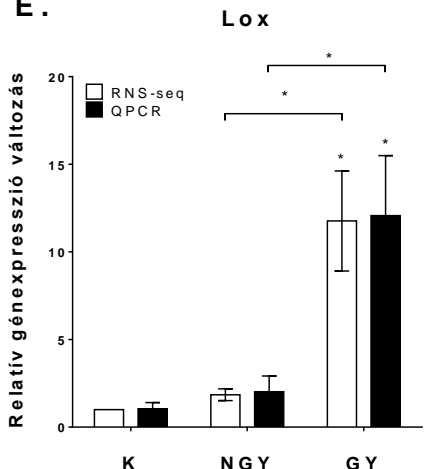

C.

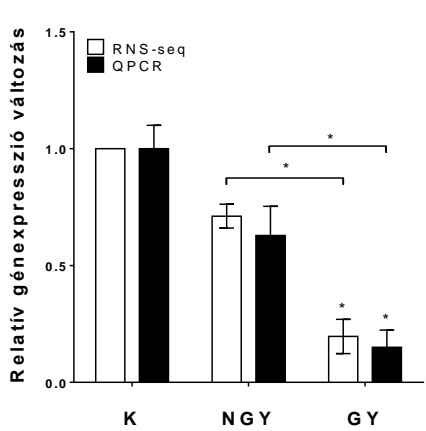

$\mathbf{F}$.

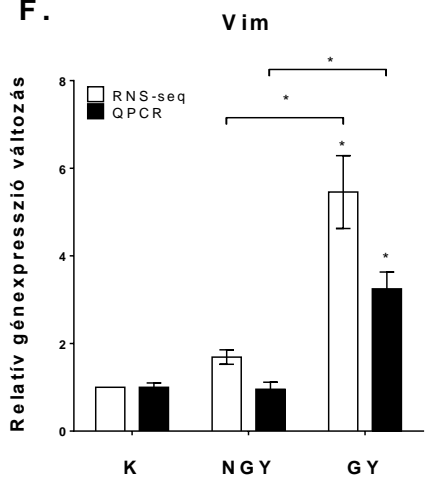

23. ábra: A patkány vastagbélgyulladást a mezenhimális markerek indukciója és az epiteliális marker repressziója jellemzi. A Zeb2, Snai1, Cdh1, Mmp9, Lox és Vim (A-F) relatív génexpresszió változása a TNBS kezelt nem-gyulladt (NGY) és a TNBS kezelt gyulladt (GY) patkány vastagbél mintákban a kontroll (K) mintákhoz viszonyítva A fehér oszlopok az RNS-Seq eredményeket, míg a fekete oszlopok a transzkriptóma analízis QPCR validálását mutatják $(*: \mathrm{p}<0,05)$.

Az IBD-s páciensekből származó minták esetén, az EMT aktiválásában szerepet játszó gének expressziója szignifikánsan nőtt az aktív-gyulladt mintákban (FGF2, FGF7, EGR1, NOTCH2, HIF1 $\alpha$, JAK2, ZEB2, SNAI1, MMP9, LOX és VIM (24A-H. és 24J-L. ábra); ellenben a CDH1 (24I. ábra) szintje ellenkező irányba változott, ahogy azt korábban a patkány vastagbél minták esetén is azonosítottuk (21.-23. ábrák). Az aktív stádiumban lévő betegek makroszkópikusan ép területeiről származó mintáiban - úgy, ahogy a TNBS kezelt patkányok nem-gyulladt vastagbél területein - sem mértünk szignifikáns változást az EMTben kulcsfontosságú gének kifejeződésében (21.-24. ábrák) 
A. FGF2

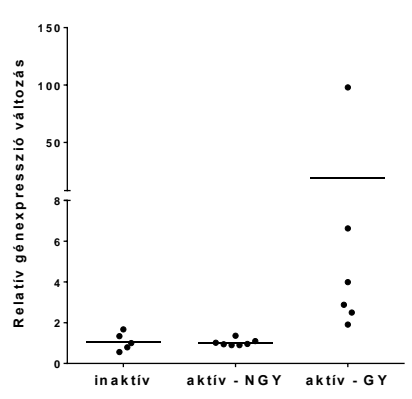

D.

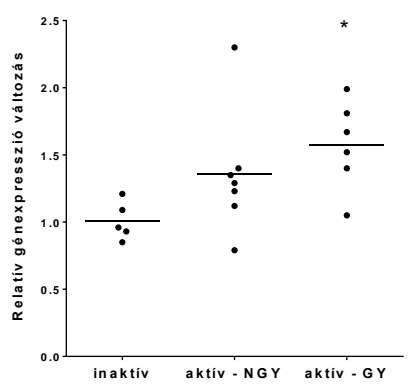

G.

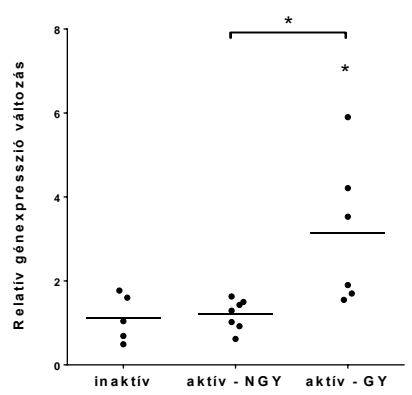

J.

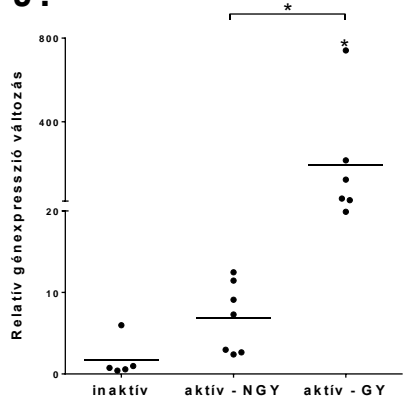

B.

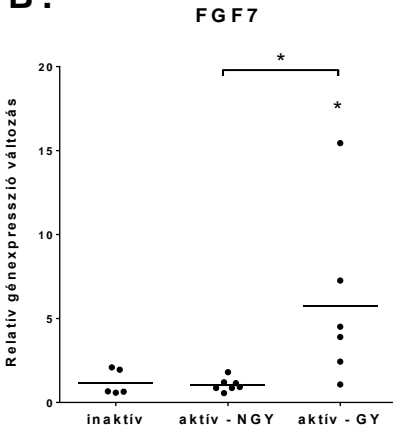

E.

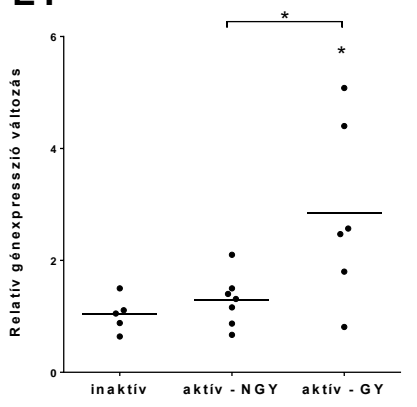

H.

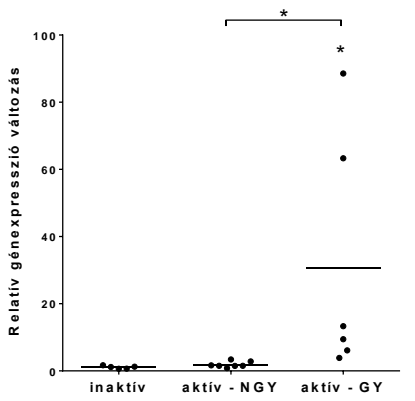

K.

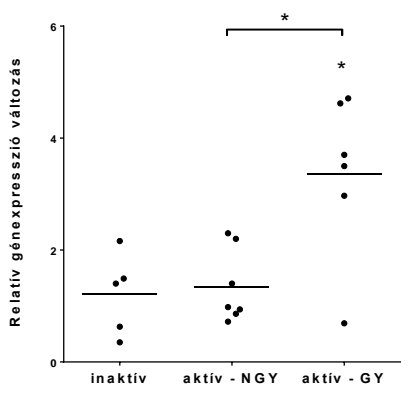

C.

EGR 1

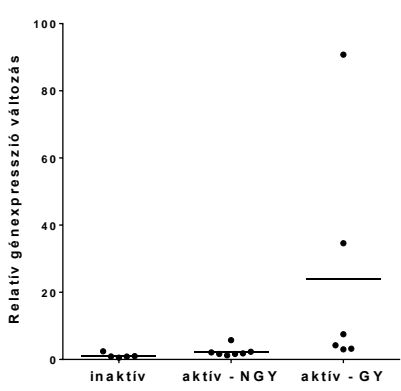

$\mathbf{F}$.

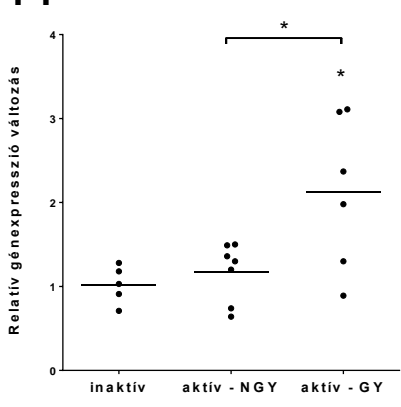

I.

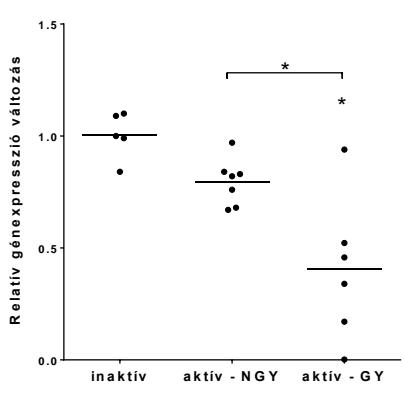

L.

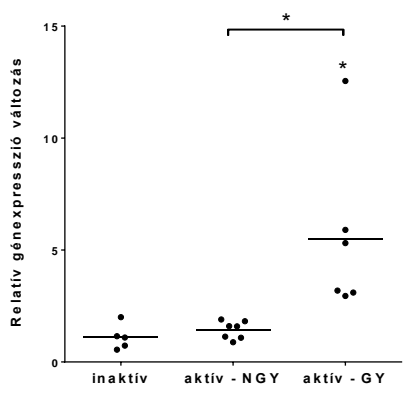

24. ábra: Az EMT-ben szerepet játszó gének kifejeződése IBD-s betegek vastagbelében. Az FGF2, FGF7, EGR1, NOTCH2, HIF1 $\alpha$, JAK2, ZEB2, SNAI1, CDH1, MMP9, LOX és VIM (A-L) relatív génexpresszió változása az aktív - nem-gyulladt (NGY) és az aktív gyulladt (GY) mintákban az inaktív humán mintákhoz viszonyítva. A pontok egyedi értékeket, míg a vízszintes vonalak, azok átlagát mutatják $(*: \mathrm{p}<0,05)$. 


\subsection{A miRNS-ek szerepe a kísérletesen előidézett vastagbélgyulladásban és IBD-ben szenvedő betegek vastagbelében}

A transzkriptóma analízis során detektált transzkriptek között a fehérje kódoló mRNS-ek mellett nem-kódoló RNS-eket is azonosítottunk, melyek egy részének expressziója szignifikánsan változott a TNBS kezelés hatására (25. ábra). Az ncRNS-ek közé tartozó miRNS-ek, hosszú hajtü struktúrákban gazdag elsődleges transzkriptumként, primiRNS-ként íródnak át, melyek kettős szálú RNS szakaszai magukban hordozzák a későbbi érett miRNS-eket. A primer transzkriptumok (néhány ezer nt) megfelelő méretüknek köszönhetően detektálhatók RNS-Seq módszerrel; ezzel ellentétben az érett miRNS-ek (2121 nt) a méretszelekciós lépésnél (> 100 nt) elvesznek a mintaelőkészítés során.

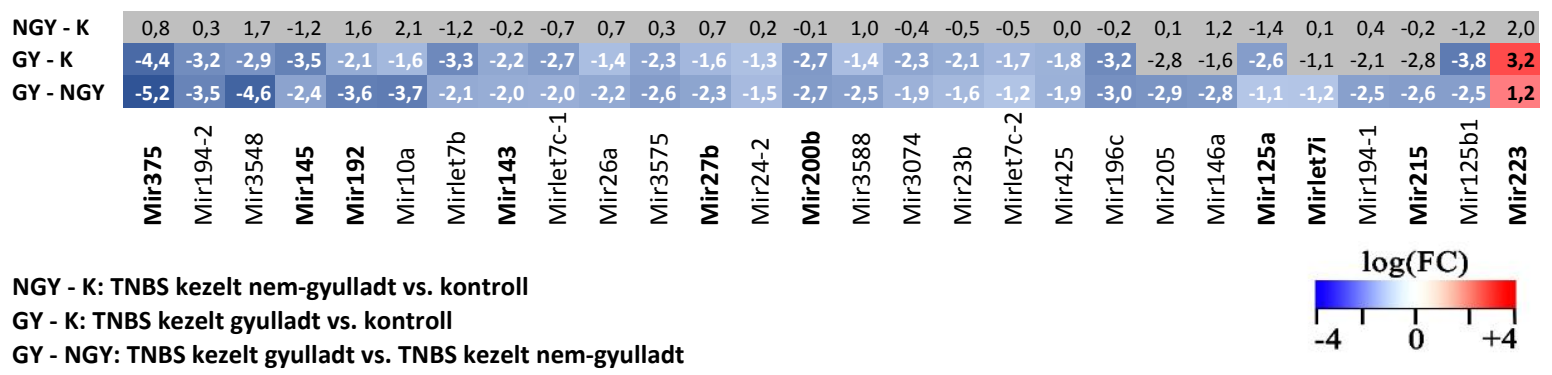

25. ábra: Az RNS-Seq során azonosított megváltozott kifejeződésü patkány miRNS prekurzorok. A nem-gyulladt vs. kontroll (NGY - K), gyulladt vs. kontroll $(\mathrm{GY}-\mathrm{K})$ és a gyulladt vs. nem-gyulladt (GY - NGY) patkány minták összehasonlítása során azonosított pri-miRNS-ek. Az értékek logaritmikus skálán kifejezett fold change, azaz log(FC) értékek, a szignifikáns változás mértékét $>1$ vagy $<-1$ teljesülése esetén színskála jelöli, a piros a növekedés, a kék a génexpresszió csökkenést szimbolizálja; míg a szürke a nem-szignifikáns értékeket jelenti.

Az összesen 26 szignifikánsan változó pri-miRNS - egyetlen kivétellel (pri-miR-223) - szignifikánsan lecsökkent expresszióját azonosítottuk a gyulladt szövetekben (25. ábra). Fontos kiemelni, hogy a közös klaszterbe tartozó miR-143 és miR-145, továbbá a miR-375 és miR-let7i pri-miRNS-einek az expressziója egyformán lecsökken (25. ábra és 26. ábra fehér oszlopai); a gyulladt szövetben emelkedett expressziót kizárólag a pri-miR-223 esetében azonosítottunk (25. ábra)

A mikroRNS-ek érése egy bonyolult, több szinten szabályozott folyamat, így az érett miRNS-ek mennyisége nem feltétlenül azonos az elsődleges transzkriptumokéval. Ezért a pri-miRNSek expressziójának meghatározása mellett néhány esetben a funkcionális, azaz 
érett miRNS-ek kifejeződését is nyomon követtük QPCR módszerrel. A miR-143 (26A. ábra fekete oszlopai), miR-145 (26B. ábra fekete oszlopai), miR-375 (26C. ábra fekete oszlopai) és miR-let7i (26D. ábra fekete oszlopai) esetében az érett miRNS-ek kifejeződése is jelentősen csökkent a patkány vastagbelek gyulladt területein: ezek az eredmények összhangban vannak az RNS-Seq során meghatározott primer transzkriptumok kifejeződésére vonatkozó adatokkal (26. ábra).

A.

m iR - 143

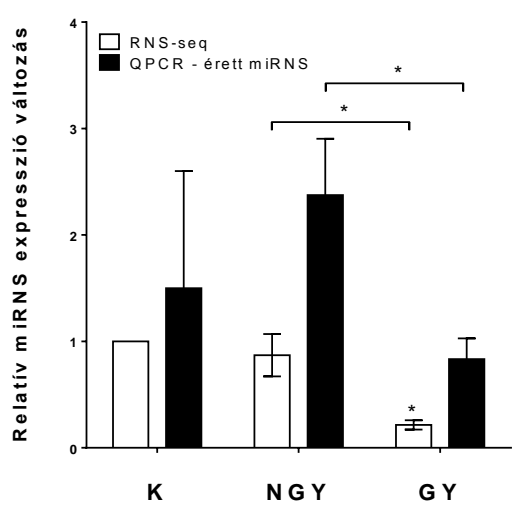

C.

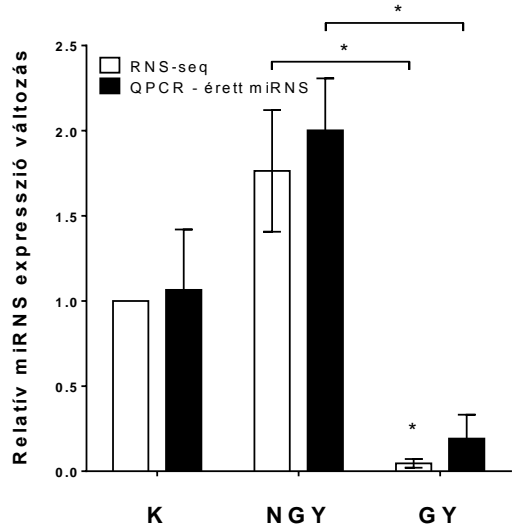

B.

m iR -145
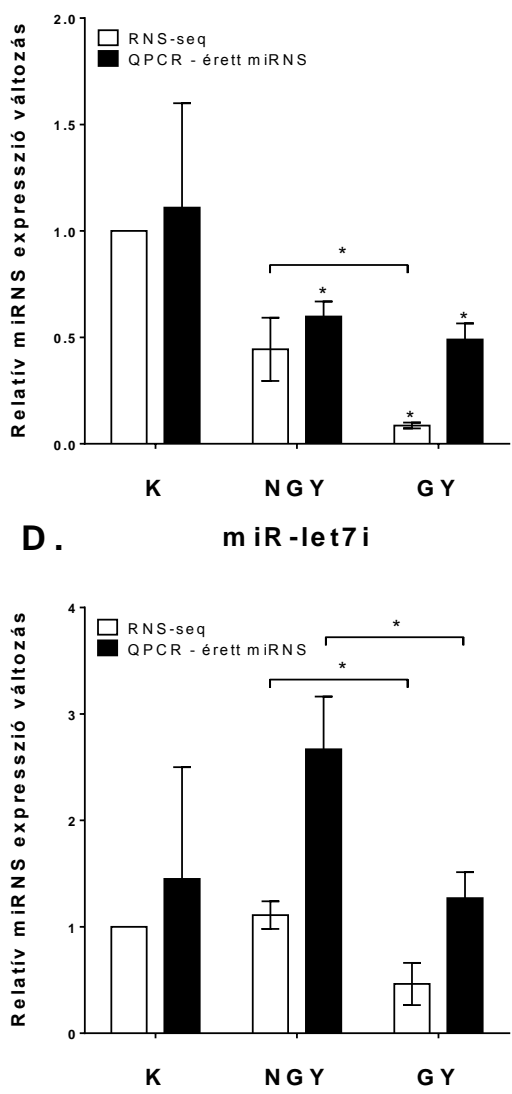

26. ábra: Az RNS-Seq által azonosított patkány miRNS prekurzorok és az érett miRNSek expressziója közötti korreláció. A miR-143/-145/-375 és -let7i (A-D) relatív expresszió változása a TNBS kezelt nem-gyulladt (NGY) és a TNBS kezelt gyulladt (GY) patkány vastagbél mintákban a kontroll (K) mintákhoz viszonyítva. A fehér oszlopok az RNS-seq eredményeket, azaz a miRNS prekurzorok kifejeződését, míg a fekete oszlopok az érett miRNS-ek QPCR módszerrel mért szintjét mutatják $(*: p<0,05)$.

A MIR-8 mikroRNS géncsaládhoz tartozó miR-200b/200a/429-et magába foglaló primer transzkriptum, illetve a MIR-192 családhoz tartozó miR-192-t és miR-215-öt kódoló 
pri-miRNS-ek szintje szignifikánsan csökkent a gyulladt vastagbélben (25. ábra). A szintén MIR-8 géncsaládhoz tartozó miR-200c/141-et tartalmazó pri-miRNS kifejeőzésdése bár ugyanúgy csökkent a gyulladt vastagbélben, azonban a változás nem volt szignifikáns. A több érett miRNS-t is magukban hordozó primer transzkriptumok esetén fontosnak tartottuk, hogy a funkcionális miRNS-ek expresszió változását is nyomon kövessük, hiszen összetettt biogenezisük miatt mennyiségük nem szükségszerüen korrelál a pri-miRNS-ekével. Ennek megfeleően tehát megmértük az érett miR-200a/b/c (27A-C. ábra), miR-429 (27E. ábra) és miR141 (27D. ábra) kifejeződését, melyek expressziója szignifikánsan csökkent a gyulladt vastagbélterületeken a kontroll és a TNBS kezelt nem-gyulladt mintákhoz képest is; csakúgy, mint az érett miR-192 (27G. ábra) és miR-215 (27F. ábra) mennyisége.

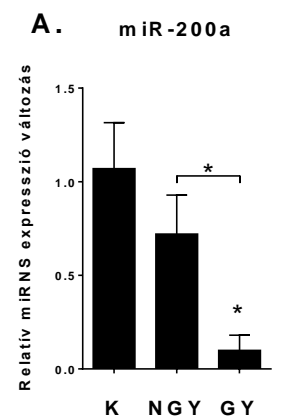

F.

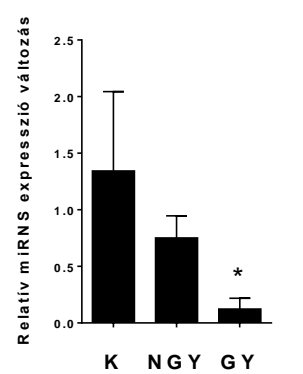

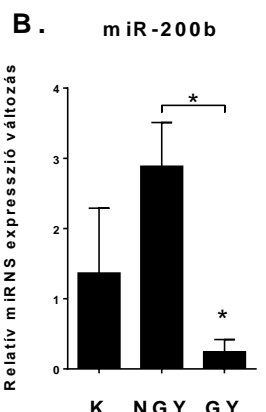

G.

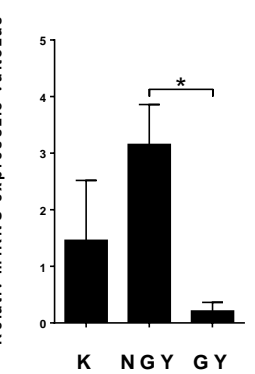

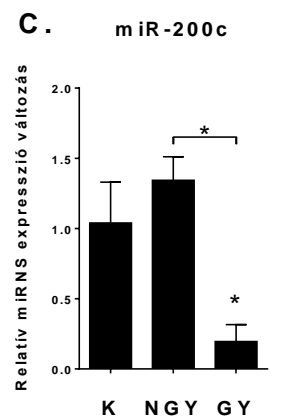

H.

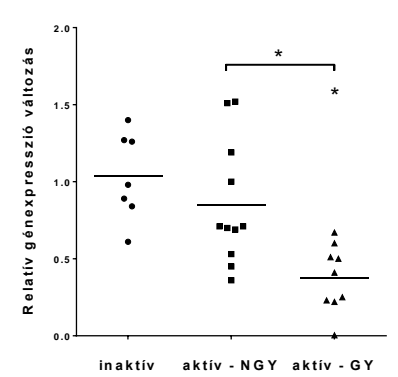

E. $\quad m i R-429$

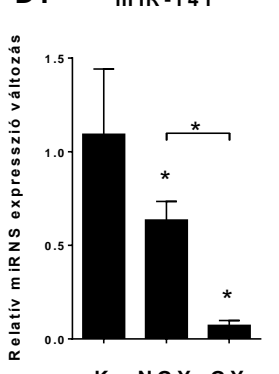

I.

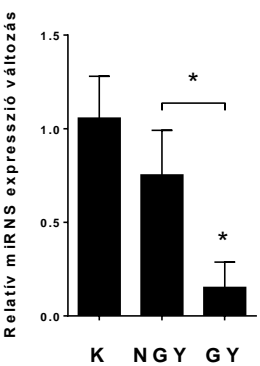

miR-192

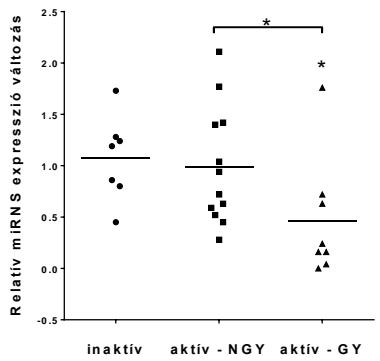

27. ábra: MIR-8 és MIR-192 mikroRNS géncsaládok tagjainak expressziója vastagbélgyulladás során. A miR-200a/b/c, miR-141/-429/-192 és -215 (A-G) relatív miRNS expresszió változása a TNBS kezelt nem-gyulladt (NGY) és a TNBS kezelt gyulladt (GY) patkány vastagbél mintákban a kontroll $(\mathrm{K})$ mintákhoz viszonyítva. A prekurzor (premiR-192) és érett mir-192 (H, I) relatív expresszió változása az aktív - nem-gyulladt (NGY) és az aktív - gyulladt (GY) mintákban az inaktív humán mintákhoz viszonyítva. A körök, négyzetek és háromszögek egyedi értékeket, míg a vízszintes vonalak, azok átlagát mutatják $(*: p<0,05)$. 
Az IBD-s páciensekből származó szövetminták esetén a pre-miR-192 (27H. ábra) és az érett miR-192 (27I. ábra) kifejeződését is nyomon követtük, melyek mennyisége szignifikánsan csökkent a gyulladt területeken.

\subsubsection{Az immunválasz posztranszkripcionális szabályozása miRNS-ek által}

A gyulladt patkány szövetekben szignifikánsan nőtt a pri-miR-223 expressziója a TNBS kezelés hatására. Korábbi tanulmányok szerint a makrofágok polarizációját gyulladás gátló M2 típus felé terelő miR-223 szintje eltérő a különböző szövet típusok között, legnagyobb mennyiségben a csontvelőben termelődik, míg a vastagbélben fiziológiás körülmények között elenyésző mennyiségben fejeződik ki [106].

Kísérleteink során mind a patkány mind a humán vastagbélből származó mintákban fokozott pri- továbbá érett miR-223 kifejeződést azonosítottunk a gyulladt szövetekben, ellenben a TNBS-kezelt nem-gyulladt patkány és az aktív de nem-gyulladt humán mintákban nem változott szignifikánsan a miR-223 mennyisége (28. ábra). Fontos megjegyezni, hogy IBD-s betegek szérumában megfigyelték, hogy a miR-223 szintje egyenesen korrelál a betegség aktivitásával, azaz aktív betegeknél megemelkedett a miR-223 mennyisége [130]. Ismert továbbá, hogy a mieloid-eredetủ sejtek által expresszált miR-223 fontos szerepet tölt be a proliferációban és a granulociták érésében [131], továbbá a CXCL2 és CCL3 kemotaktikus fehérjéket kódoló gének direkt gátlásával szabályozza az immunsejtek toborzását [132], melyek expressziója szignifikánsan változott a TNBS kezelt patkányok

gyulladt vastagbél területein (F1. ábra, 12E. ábra). Tehát az általunk detektált miR-223 a vastagbélbe infiltráló immunsejtekből származhat, melyek valószínüsíthető feladata a szöveti homeosztázis helyreállítása a gyulladáskeltő TNF $\alpha$, IL1 $\beta$, IL6 és NLRP3 gátlásán keresztül. 

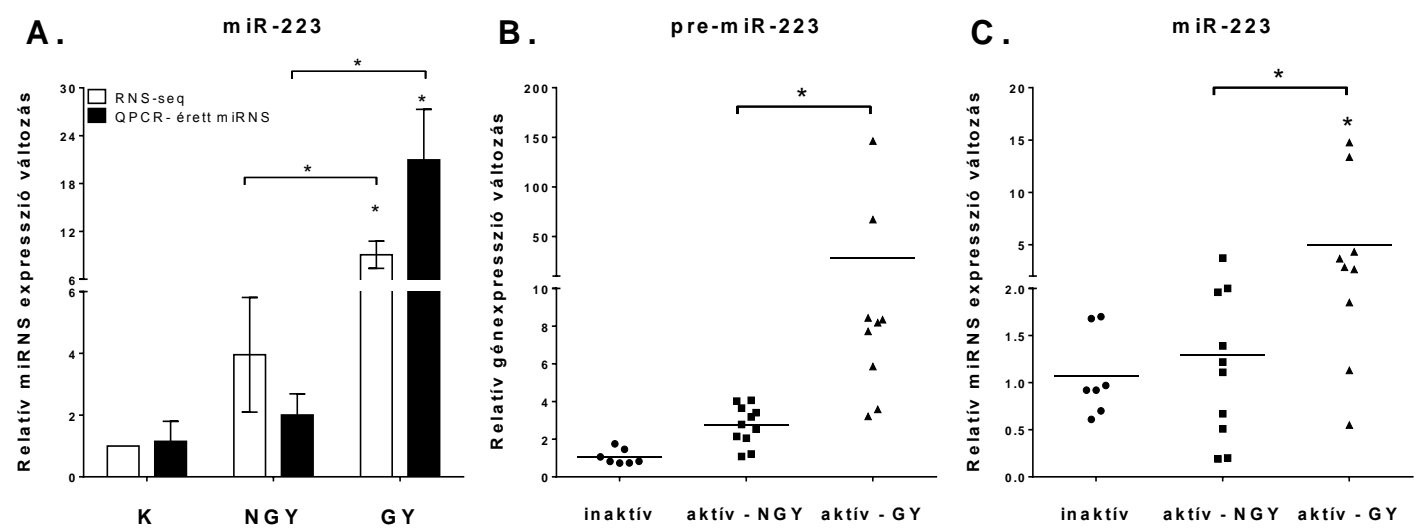

28. ábra: A gyulladásos folyamatokban szerepet játszó miR-223 expressziójának változása a vastagbélgyulladás során. A prekurzor (pri-miR-223) és érett miR-223 (A) relatív expresszió változása a TNBS kezelt nem-gyulladt (NGY) és a TNBS kezelt gyulladt (GY) patkány vastagbél mintákban a kontroll $(\mathrm{K})$ mintákhoz viszonyítva. A fehér oszlopok az RNS-Seq eredményeket, azaz a pri-miR-223 kifejeződését, míg a fekete oszlopok az érett miR-223 QPCR módszerrel mért szintjét ábrázolják. A prekurzor (pre-miR-223) és érett mir$223(\mathbf{B}, \mathbf{C})$ relatív expresszió változása az aktív - nem-gyulladt (NGY) és az aktív - gyulladt (GY) humán mintákban az inaktív mintákhoz viszonyítva. A körök, négyzetek és háromszögek egyedi értékeket, míg a vízszintes vonalak, azok átlagát ábrázolják (*: p < $0,05)$.

A gyulladásos folyamatokban szerepet játszó miRNS-ek egyike a miR-27b, melynek szekvenciája gerincesek között erősen konzervált. Targetjei közül a CCL4, ABCA1 és CYP1B1 a gyulladásos folyamatok szabályozói [133-136] és kifejeződésük szignifikánsan megemelkedett a gyulladt patkány szövetmintákban (F1. ábra). A patkány vastagbél gyulladt területein a miR-27b kifejeződésének jelentős csökkenését figyeltük meg, mind a prekurzorok, mind az érett miRNS szintjén. Az RNS-Seq-ben detektált csökkent pri-miR27b mennyiségét, QPCR módszerrel is validáltuk (29A. ábra), továbbá megmértük az érett miR-27b expresszióját (29B. ábra). Az IBD-s betegekből származó minták vizsgálatakor azt tapasztaltuk, hogy az aktív-nem-gyulladt mintákhoz képest az aktív-gyulladt mintákban szignifikánsan csökken az érett miR-27b kifejeződése (29C. ábra), ahogy azt az in vivo patkány modellnél is megfigyeltük (29B. ábra). 
A.

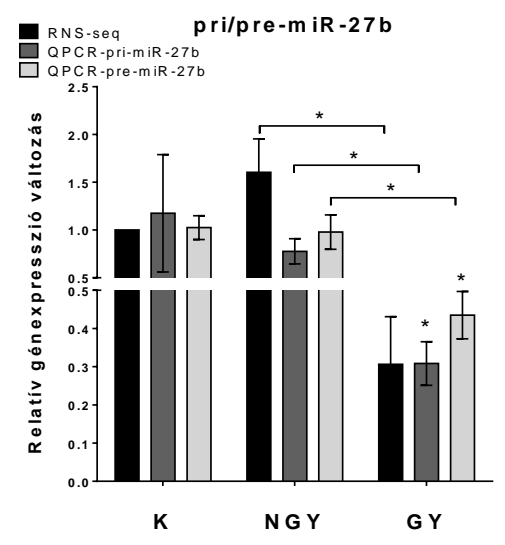

B.

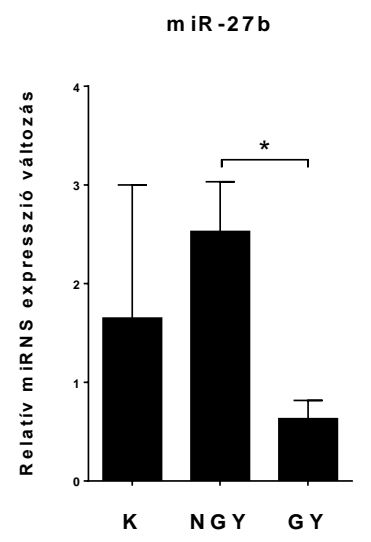

C.

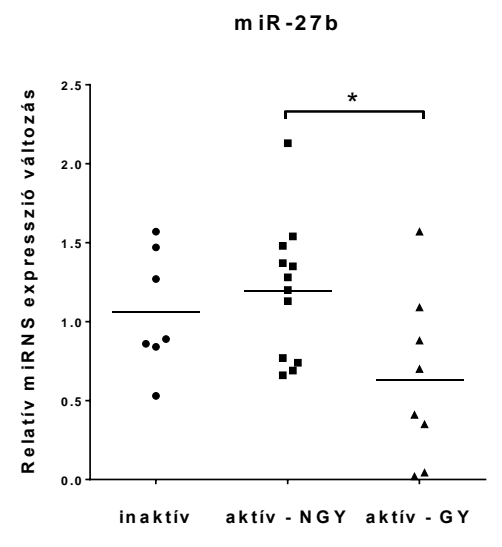

D.

M m p 13

E.

M M P 13
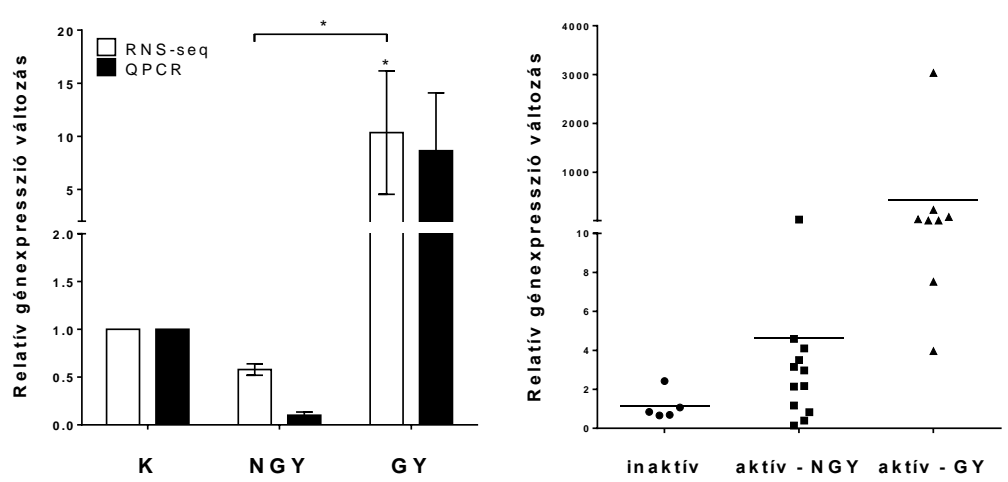

29. ábra: A gyulladáskeltő TNF $\alpha$ többszintü szabályozásában résztvevő molekulák expressziója a gyulladásos folyamatokban. A prekurzor pri-/pre-miR-27b (A) és érett miR27b (B), valamint Mmp13 (D) relatív expresszió változása a TNBS kezelt nem-gyulladt (NGY) és a TNBS kezelt gyulladt (GY) patkány vastagbél mintákban a kontroll (K) mintákhoz viszonyítva. A érett mir-27b (C) és MMP13 (E) relatív expresszió változása az aktív - nem-gyulladt (NGY) és az aktív - gyulladt (GY) mintákban az inaktív humán izolátumokhoz viszonyítva. A körök, négyzetek és háromszögek egyedi értékeket, míg a vízszintes vonalak, azok átlagát mutatják $(*: \mathrm{p}<0,05)$.

Az MMP13-at kódoló gén 3'UTR régiójában elhelyezkedő miR-27b kötőhely konzervált az emlösök között, így a patkány és a humán MMP13 között is (www.targetscan.org). Az MMP13 az inaktív pro-TNFa hasítása révén fokozza a gyulladásos választ, míg humán kondrocitákban a miR-27b képes gátolni az MMP13 kifejeződését [19, 137]. A TNBS kezelt gyulladt patkány vastagbél mintákban és az aktív stádiumban lévő IBDs betegek gyulladt szöveteiben az emelkedett TNFa expresszió (12D. és 13C. ábra), szignifikánsan megnövekedett MMP13 kifejeződéssel társult (29D. és E. ábra). 


\subsubsection{Az IBD során indukálódott EMT szabályozása miRNS-ek által}

A gyulladásos folyamatok szabályozásán kívül, az RNS-Seq által azonosított megváltozott expressziójú pri-miRNS-ek többsége olyan miRNS-ek éretlen formái, amelyek az epiteliális-mezenhimális tranzícióban kulcsfontosságú fehérjéket kódoló gének inhibítorai. Ahogy korábban bemutattuk, mind patkány mind az IBD-s páciensekböl származó minták esetén, a vastagbél gyulladt területein az EMT-t előidéző gének kifejeződése kivétel nélkül szignifikánsan emelkedett, míg az epiteliális fenotípus kialakításáért felelős CDH1 expressziója csökkent (21.-24. ábrák). Annak érdekében, hogy az EMT posztranszkripcionális szabályozásában szerepet játszó molekulák expressziós változását nyomon követhessük az in vivo kísérletesen előidézett patkány és az IBD-s betegek vastagbélgyulladása esetén is, a transzkriptóma analízis során detektált primer transzkriptumok mellett, további az EMT-ben targettel rendelkező érett miRNS-ek mennyiségét is megvizsgáltuk QPCR módszerrel.

Az EMT-t előidéző transzkripciós faktorok, a ZEB2, SNAI1 és TWIST1 miRNS-ek promóter régióihoz kapcsolódva gátolják utóbbiak kifejeződését, azonban önmaguk is miRNS-ek szabályozása alatt állnak [138, 139]. A már korábban bemutatott MIR8 és MIR192 miRNS géncsaládhoz tartozó miR-200b és miR-192 a ZEB2 ismert inhibítorai, ugyanakkor maga a ZEB2 képes a miR-200b expressziójának gátlására [85]. A TWIST1 transzkripciós represszor szabályozza a miR-192 kifejeződését, ami további EMT gének, például az EGR1 és FGF2 inhibítora is. A SNAI1 pedig a miR-375 kifejeződésének gátlásával járul hozzá targetje, a JAK2 expressziójának növekedéséhez.

Korábban bemutatott adataink egyértelmüen azonosították az EMT-t mint a vastagbélgyulladásban kiemelt szerepü molekuláris folyamatot, amely akár a gyulladás és tumorigenezis közötti kapocs is lehet. Emiatt fontosanak tartottuk, hogy az EMT szabályozásában ismerten szerepet játszó érett miRNS-ek mennyiségi változását is megmérjük, olyanokét is amelyek prekurzorait az RNS-Seq során egyáltalán nem azonosítottuk vagy nem változott szignifikánsan a kifejeződésük. Ilyen pl. a miR-199a, ami a SNAI1 szabályozása mellett a CDH2, AXL és HIF1 $\alpha$ inhibítora is. Méréseink hasonló expressziós mintázatot azonosítottak a korábban bemutatott miRNS-mRNS target párokéval 
a patkány vastagbél gyulladt területein: ahol a gátló miR-199a expressziója csökkent (30A. ábra) ott a target Snail kifejeződése megemelkedett (23B. ábra). A miR-199a - SNAI1 RNS mennyisége közötti inverz korrelációt az IBD-s betegek gyulladt mintáiban is azonosítottuk, ahol a miR-199a mennyisége szignifikánsan csökkent (30B. ábra), ezzel ellentétben a SNAI1 expressziója nőtt (24H. ábra).
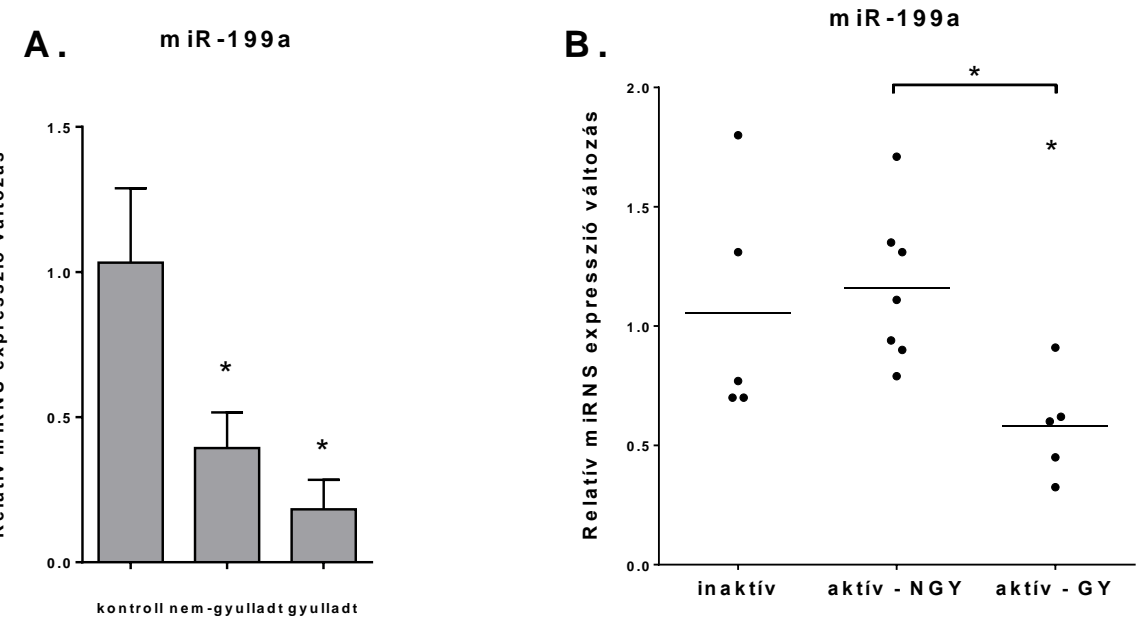

C. $\quad$ m iR -107

D.

m iR -30a

E. $\quad m$ iR $-125 a$
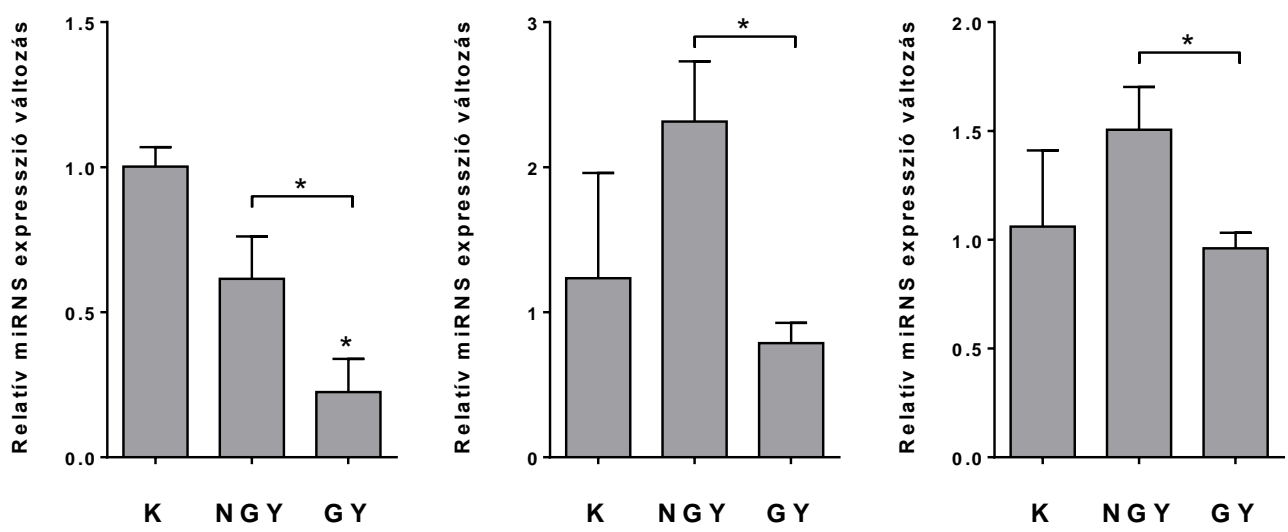

30. ábra: Az EMT-t szabályozó miRNS-ek kifejeződése a gyulladt szövetekben. A miR199a/107/-30a/ és -125a (A, C-E) relatív miRNS expresszió változása a TNBS kezelt nemgyulladt (NGY) és a TNBS kezelt gyulladt (GY) patkány vastagbél mintákban a kontroll (K) mintákhoz viszonyítva. A érett mir-199a (B) relatív miRNS expresszió változása az aktív nem-gyulladt (NGY) és az aktív - gyulladt (GY) humán mintákban az inaktív mintákhoz viszonyítva. A körök egyedi értékeket, míg a vízszintes vonalak, azok átlagát mutatják (*: $\mathrm{p}$ $<0,05)$. 
Emellett a HIF1 $\alpha$ gátlásában szerepet játszó miR-107 [93] (30C. ábra), a VIM inhibítora a miR-30a [140] (30D. ábra), és az MMP9 negatív regulátoraként ismert miR-125a (30E. ábra) kifejeződése is szignifikánsan csökkent a gyulladt patkány vastagbélben, ahol targetjeik expressziója szignifikánsan megemelkedett (22. és 23. ábra). További ismert ellentétes irányú expressziót mutató miRNS-mRNS target párok az EMT szabályozásában a fentiek mellett még: a már korábban bemutatott miR-143 (26A. ábra) és targetje az FGF7 (21B. ábra), valamint a gyulladás szabályozásában jelentős miR-27b (29B. ábra) és célmolekulája, a CDH5 [141] (F1. ábra).

Az in vivo patkány modell és az IBD-s betegekből származó izolátumok vizsgálata során egyaránt megállapítottuk, hogy az EMT-t indukáló gének gátlásában résztvevő miRNS-ek mindegyikének szignifikánsan csökkent a kifejezödése a gyulladt szövetekben, ahol targetjeik kifejeződése inverz módon, szignifikánsan nőtt. A miRNS-mRNS target párok gyulladt/nem-gyulladt szövetterületek közötti szignifikáns különbsége az IBD-s betegek körében gyakrabban kialakuló vastagbélrák molekuláris hátterének szabályozásában is szerepet játszhat. 


\section{DISZKUSSZIÓ}

A tápcsatornát érintő krónikus gyulladással járó gyulladásos bélbetegségek (IBD) multifaktoriális eredetü betegségek, melyek pontos eredete mindezidáig ismeretlen. Az elmúlt évtizedekben számtalan genetikai kockázati tényezőt azonosítottak, melyekről azt gondolják, hogy a CD és UC kialakulásának hátterében állnak; azonban az ikertanulmányok viszonylag alacsony konkordanciát állapítottak meg a genetikai faktorok megléte és a betegség manifesztálódása között [142]. A teljes genom asszociációs vizsgálatok talán legfontosabb mondanivalója éppen az, hogy a legtöbb genetikai rizikó faktorként elfogadott mutáció, olyan géneket érint melyek a szervezet és a külső- valamint mikrobiális környezet közötti interakciók fenntartásában és szabályozásában fontosak (pl.: NOD2, FUT2). Az IBD patomechanizmusában vitathatatlan a mikrobiom összetételének és az életmódnak beleértve a táplálkozási szokásokat, a lakóhelyből adódó napfényes órák számát, a testmozgás hiányát vagy a dohányzást - a jelentősége, de ezek a tényezők csak genetikailag fogékony egyénekben eredményezik az IBD kialakulását. A legszembetünőbb bizonyítéka annak, hogy az IBD kialakulására valószínüleg az életmódbeli és a környezeti tényezők is hatással lehetnek az az úgynevezett modern- vagy fejlett társadalmakra jellemző magas előfordulási ráta a fejlődő országokkal szemben [142]. Emellett az IBD-ben szenvedő betegek száma világszerte folyamatos növekedést is mutat, ami miatt egyre fontosabb a betegség molekuláris hátterének pontos megértése és új terápiás megoldások kifejlesztése.

A gyulladásos bélbetegségek tanulmányozására számos in vivo rágcsáló modell áll rendelkezésre: a genetikailag módosított egér rendszerektől kezdve, a kémiai ágensekkel előidézett vastagbélgyulladás vizsgálatára alkalmas modellekig [113]. Az IBD tanulmányozására általánosan elfogadott in vivo TNBS indukált patkány vastagbélgyulladás modellben, a TNBS a nyálkahártya integritását megbontva szórványosan elhelyezkedő léziókat hoz létre a vastagbél mentén, melyeket makroszkópikusan ép szöveti régiók váltanak. Ez a tagoltság jellemző az IBD-s betegek tápcsatornájára is, ahol a fekélyes részeket fenotípusosan normális szövetszakaszok tagolják. A patkány modell használatakor alkalmazott hagyományos mintavétel a vastagbélből hosszanti irányba történik, ennek eredményeképpen a különböző állatokból - melyekben eltérő mértékben és pozícióban 
találhatók gyulladt és nem-gyulladt szövetrégiók - származó izolátumokban eltérő arányban lesznek jelen a léziós és ép részek. Ebből egyrészt az következik, hogy: A) a mintapopuláció kevert mintákból fog állni; B) a gyulladt/nem-gyulladt részek közötti feltételezett génexpressziós különbségek miatt a valódi változások elmosódhatnak, kiegyenlítődhetnek; C) a gyulladt vagy a nem-gyulladt területekre jellemző valós génexpressziós mintázatok egyikét sem tükrözik majd az eredmények.

Ezen problémák kiküszöbölése érdekében módosítottuk a mintavétel módját a TNBS által kiváltott vastagbélgyulladás patkány modelljének alkalmazásakor: a TNBS kezelt állatok makroszkópikusan jól megkülönböztethető gyulladt és nem-gyulladt szövetrégiókból is izoláltunk mintákat, míg a kontroll patkányok vastagbeleiből véletlenszerüen gyüjtöttük be az izolátumokat (6. ábra). A mintacsoportok, azaz a kontroll, TNBS kezelt nem-gyulladt és TNBS kezelt gyulladt izolátumok közötti globális génexpressziós különbségek feltérképezésére RNS-Seq alkalmazásával teljes transzkriptóma vizsgálatot végeztünk. A transzkriptóma analízis bioinformatikai feldolgozása után létrejövő adathalmaz teljes körü értelmezése érdekében többdimenziós skálázással (MDS) csoportosítottuk az egyéni mintákat a köztük lévő transzkripcionális különbségek és hasonlóságok alapján (7A. ábra). Az MDS egyértelmúen igazolta azon feltevésünket miszerint a TNBS kezelt nem-gyulladt és gyulladt vastagbél régiók között jelentős a génexpressziós különbség. A korábban csak makroszkópikus megfigyelések alapján besorolt izolátumok génexpressziós mintázatuk szintjén is egy-egy csoportba klasztereződtek, továbbá a három csoport egymástól teljesen elkülönült. A szignifikánsan változó transzkriptek hőtérképen való ábrázolása (7B. ábra) is alátámasztotta az MDS során megfigyelt eredményeket: a különböző csoportok közötti génexpressziós különbséget, illetve az egy csoportba sorolt minták közötti globális transzkripciós hasonlóságot. Mivel két független módszerrel is arra a következtetésre jutottunk, hogy a nem-gyulladt és gyulladt szakaszok transzkripcionális szinten teljesen különbözőek, ezért a módosított mintagyüjtési eljárást a TNBS által kiváltott vastagbélgyulladás vizsgálata során indokoltnak és relevánsnak találjuk a hagyományos módszerrel szemben.

Eredményeink számszerüsítése érdekében összehasonlítottuk az egyes mintákat/mintacsoportokat (8. ábra). Az összes azonosított transzkriptum közül 
megközelítőleg 3800 változott szignifikánsan valamely két mintacsoport között. A szignifikánsan változó expressziójú gének közötti lehetséges funkcionális kapcsolatok egyszerübb értelmezése céljából útvonal elemzést végeztünk. Megállapítottuk, hogy a legszignifikánsabban változó kanonikus útvonalak a gyulladt területeken az immunsejtek közötti kommunikációval, az immunsejtek toborzásával, a veszély jelek felismerésével, a gyulladásos válasz szabályozásával, valamint a szövetek védelmével és regenerálásával kapcsolatosak (9. és 10. táblázat). Jelentősen megváltozott a leukociták, köztük az agranulociták és granulociták véráramból a gyulladt szöveti állományba való vándorlását segítő molekulákat magába foglaló szignalizációs útvonalak aktivitása valamint számos a

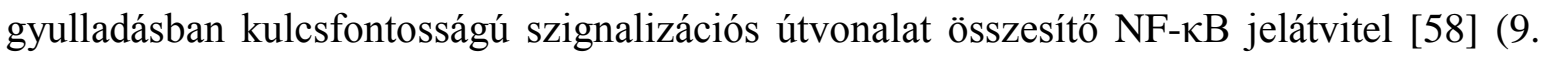
táblázat).

A veleszületett immunválasz a mikrobiális sejtalkotók vagy saját sérült sejtekböl származó molekulák mintázatfelismerő receptorok (PRR) általi felismerését követően indukálódik [2]. A PRR jelátviteli útvonal aktiválódását, továbbá a mintázatfelismerő TLR és NLR receptorok szignifikánsan megváltozott kifejeződését figyeltük meg a TNBS kezelt patkány vastagbelek gyulladt szakaszaiban (9. ábra). Az elsőként azonosított IBD-re hajlamosító mutációt egy NLR receptorban, a NOD2-ben azonosították, mely a bakteriális eredetü molekulák felismerését követően gyulladáskeltő gének kifejeződését idézi elő [7, 14, 15]. A transzkriptóma analízis során a Nod2 (10A. ábra) megemelkedett expresszióját figyeltük meg a TNBS kezelt patkány vastagbél gyulladt területein, míg a nem-gyulladt mintákban nem változott a kifejeződése. RNS-Seq eredményeinket QPCR módszerrel is validáltuk, melyek a Nod2 esetében és a dolgozatban bemutatott további 37 fehérjekódoló gén esetében is teljes mértékig korreláltak. A gyulladáskeltő citokinek érését segítő inflammaszóma alkotó NLR receptorok közül az NLRP3 (10D. ábra) és szubszrátjai az IL1 $\beta$ és IL33 szintje szignifikánsan megemelkedett a gyulladt területeken (11. ábra); ellenben a gyulladásgátló hatású NLRP6 (10F. és 11. ábra) és az azt szabályozó PPARy (F1. ábra) expressziója szignifikánsan csökkent. A mintázatfelismerő receptorok génexpressziós mintázatára jellemző a gyulladáskeltő gének fokozott, és a gyulladásgátló molekulák csökkent kifejeződése a TNBS kezelt patkányok gyulladt szövetrégióiban. 
A PRR-ek ligand kötése kemotaktikus molekulák, citokinek és kemokinek expresszióját indukálja, melyek az immunsejtek szöveti infiltrációját idézik elő [18]. A gyulladás markereiként is ismert TNF $\alpha$, IL1 $\beta$, IL6, IL10, CCL3 és CXCL1 kifejeződése szignifikánsan nőtt a gyulladt szövetekben, azonban a TNBS kezelt nem-gyullat területeken nem változott az expressziójuk (12. ábra). Az in vivo modellben azonosított változások relevanciájának igazolására IBD-s betegek vastagbeleinek gyulladt és nem-gyulladt részeiről begyüjtött szövetmintákat, inaktív betegekből származó mintákhoz hasonlítottunk. Ahogy a rágcsáló rendszerben is láthattuk, a gyulladáskeltő citokinek kifejeződése szignifikánsan megemelkedett az IBD-s betegek gyulladt mintáiban, mind az inaktív, mind a relapszáló betegek nem-gyulladt mintáihoz viszonyítva, ami egyértelmű bizonyítéka az aktív gyulladás jelenlétének (13. ábra). Az IBD-s páciensek tüneteinek enyhítésére kifejlesztett terápiás módszerek főként a fent említett pro-inflammatórikus citokinek, leginkább a TNFa gátlásán alapulnak [44]. Ez a módszer azonban nem minden betegnél eredményez javulást, és csak a gyulladás tüneti kezelésére alkalmas, de nem jelent tartós gyógymódot az IBD-vel szemben.

Miután az IBD patomechanizmusával már korábban kapcsolatba hozott gének expressziós mintázatát megvizsgáltuk a TNBS indukált patkány vastagbélgyulladás rendszerben, valamint IBD-s páciensekből származó szövetminták segítségével is igazoltuk a modell hitelességét, a betegség kezelésére alkalmas új célmolekulák azonosítására törekedtünk.

A gyulladásos válasz során a sérült sejtekből felszabaduló fehérjék jelátviteli kaszkádot indítanak be. Annak érdekében, hogy ez az öngerjesztő folyamat ne váljon irányíthatatlanná és a saját szervekre, szövetekre károssá, szükségesek a gyulladást gátló visszacsatolások. A TLR-ek által kiváltott gyulladás negatív szabályozóiként ismert TAM receptorok [29] és ligandjaik különböző irányú génexpressziós változását figyeltük meg a TNBS indukált patkány IBD modellben (14. ábra); ahol az Axl kifejeződése szignifikánsan megemelkedett mRNS (14B. ábra) és fehérje (15. ábra) szinten is a gyulladt bélszakaszokban, addig a Mertk (14C. ábra) és Tyro3 (14A. ábra) mRNS szintje csökkent az azonos szövetrégiókban. Az IBD-s betegek vastagbeleiben csak az AXL (16B. ábra) kifejeződése változott szignifikánsan, ahol az aktív-gyulladt mintákban emelkedett mRNS expresszióját detektáltuk. A pleiotróp hatású AXL megemelkedett kifejeződésének több oka is lehet a 
gyulladt területeken: negatív regulátorként és a fagocitózis elösegítése által [32] a szöveti homeosztázis helyreállítását támogathatja; másrészt, mint az epiteliális - mezenhimális tranzíció aktivátora [64] az IBD-s betegeknél gyakran kialakuló vastagbélrák kockázatát növelheti.

A transzkriptóma vizsgálat során a legjelentősebb expressziós változások a gyulladt szöveteket jellemezték, míg a nem-gyulladt mintákban jóval kevesebb szignifikánsan változó transzkriptet azonosítottunk (7B. és 8 . ábra). Érdekes módon, ha a nyálkahártya védelméért felelős mucinok és azok glikolizációjában szerepet játszó fehérjéket kódoló gének expresszióját követtük nyomon, akkor szignifikáns eltérést tapasztaltunk a TNBS kezelt nem-gyulladt patkány vastagbelekben (17-20. ábrák). Az epitél sejtek felszínét borító kettős nyákréteg kialakításáért felelős MUC2 (17. és 18A. ábra) expressziója szignifikánsan emelkedett a TNBS kezelt patkány vastagbél ép területein. Korábbi tanulmányok említik a MUC2 jelentőségét UC-s betegeknél - melynek kifejeződésben nem találtak jelentős változást - azonban vizsgálataik során nem különböztették meg a relapszló betegek gyulladt és nem-gyulladt területeit [40]. Az általunk feldolgozott, IBD-s páciensekből származó biopsziák vizsgálatakor a MUC2 (18B. ábra) kifejeződése az aktív stádiumban lévő betegek gyulladt és nem-gyulladt vastagbél területein eltérő volt, a patkány vastagbélhez hasonlóan, a makroszkópikusan normális területeken magasabb, mint a fekélyes részeken. Feltételezhető, hogy az emberi és a patkány minták esetén is a gyulladt területek mellett elhelyezkedő, még ép területeken megfigyelt magasabb MUC2 expresszió fokozott védelmet jelenthet a további szöveti károsodással szemben.

A tápcsatornát bélelő epitélium védelmében fontos szerepe van a glikokalix szintézisét végző glikoziltrasnzferázoknak, köztük fukoziltranszferázoknak is [23], melyek jelentős expresszió változását azonosítottuk a nem-gyulladt és gyulladt patkány vastagbél területeken is (18-20. ábrák). A Muc2 és Dmbt1 mRNS-ekhez hasonlóan szignifikánsan nőtt a kifejeződése az A4gnt, a B4galnt2, a Fut4 és a Fut9 géneknek a TNBS kezelt nem-gyulladt szövetrégiókban (19-20. ábrák), velük ellentétben a Fut1 és Fut2 kifejeződése szignifikánsan csökkent a gyulladt területeken (20. ábra). A glikolizációért felelős fehérjéket kódoló gének expressziós mintázatának TNBS kezelést követő változása arra utal, hogy a nem-gyulladt 
területeken a szervezet próbálja fenntartani a szöveti homeosztázist és megóvni a nyálkahártyát az esetleges sérülésektől.

A TNBS indukált vastagbélgyulladás in vivo patkány modelljének transzkriptóma vizsgálat során számos olyan molekulát is azonosítottunk, melyek szerepe nemcsak a gyulladás szabályozásában, hanem a daganatos elváltozások kialakulásában is ismert. Ezek vizsgálatát azért tartottuk fontosnak, mert az IBD-s betegekre jellemző elhúzódó, krónikus gyulladás jelentősen növeli a vastagbélrák kialakulásának kockázatát [43], melynek kifejlődésében a metasztázis képződést elősegítő epiteliális-mezenhimális tranzíció (EMT) kulcsfontosságú folyamat [59]. Az EMT molekuláris komponensei szignifikásan aktiválódtak a TNBS által kiváltott vastagbélgyulladás és az IBD-s páciensek vastagbelében egyaránt (21-24. ábrák). A mezenhimális fenotípus kialakításáért is felelös növekedési faktorokat (FGF2, FGF7, EGR1; 21. és 24A-C. ábra) és jeltovábbító molekulákat (NOTCH1/2, JAK2, HIF1 $\alpha$; 22. és 24D-F. ábra) kódoló mRNS-ek kifejeződése szignifikánsan megemelkedett az IBD-s betegek és a TNBS kezelt patkányok gyulladt vastagbélrégióiban; akárcsak az EMT-t indukáló transzkripciós faktorok (ZEB2, SNAI1; 23A-B. és 24G-H. ábra) és az ECM átalakításban szerepet játszó MMP9 (23D. és 24J. ábra), valamint a VIM (23F. és 24L. ábra) és LOX (23E. és 24K. ábra) mRNS expressziója. Ellenben az epiteliális marker, CDH1 (23C. éás 24I. ábra) mRNS kifejeződése szignifikánsan csökkent a gyulladt területeken.

Az RNS-Seq során azonosított transzkriptek között a mRNS-ek mellett pri-miRNSeket is detektáltunk, melyek kettős szálú RNS szakaszai magukban hordozzák a későbbi érett miRNS-eket. A miRNS-ek bonyolult, több szinten szabályozott biogenezise miatt, a változó expressziójú pri-miRNS-ek érett miRNS származékainak kifejeződését QPCR-rel követtük nyomon. A szignifikánsan változó kifejeződésű pri-miRNS-ek többsége csökkent a gyulladt szövetekben (25. ábra), és ezeket a változásokat az érett miRNS-ek mennyiségében is megfigyelhettük (26-30. ábra). Jelentősen csökkent a kifejeződése többek között a MIR8 és MIR192 miRNS géncsalád tagjainak (miR-200a/b/c, -141, -429; miR-192, -215; 27A-G. ábra), a közös klaszterben elhelyezkedő miR-143/-145-nek (26A-B. ábra), valamint miR375-nek (26C. ábra). Közös jellemzőjük ezeknek a miRNS-eknek, hogy mindegyikük az EMT-t indukáló gén/ek inhibítora [84]. A miR-200b és ZEB2 között negatív visszacsatolás 
figyelhető meg, azaz gátolják egymás kifejeződését [85]. Továbbá a ZEB2 inhibítora a miR192 is, melyet a TWIST1 transzkripciós represszor szabályoz [87]. A miR-192 (27H-I. ábra) csökkent kifejeződését az IBD-s betegek gyulladt vastagbélrégióiban is megfigyelhettük, ahol további targetjei, a már bemutatott EGR1 (24C. ábra) és FGF2 (24A. ábra) kifejeződése fordítottan változott, azaz szignifikánsan emelkedett. Szintén fontos EMT indukáló transzkripciós faktor, a SNAI1 pedig a miR-375 kifejeződésének gátlásával járul hozzá targetje [92], a JAK2 expressziójának növekedéséhez [91].

Csökkenés

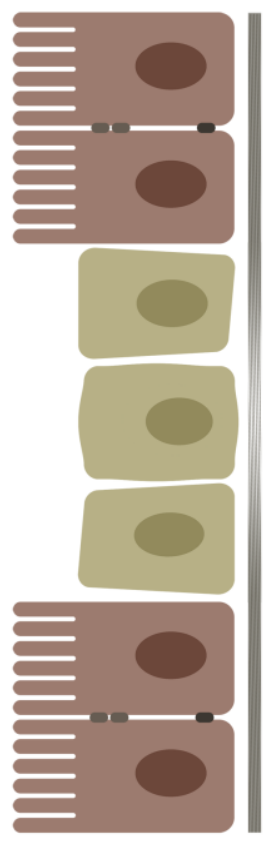

\section{Cdh1} miR-200b

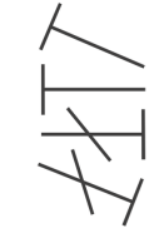

miR-192

$\operatorname{miR}-143$

miR-30a

miR-107
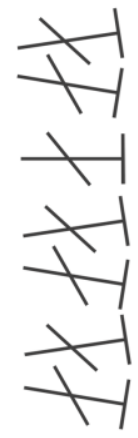

$\operatorname{miR}-375$

$\operatorname{miR}-125 a$

\section{Növekedés}

Zeb2

Lox

Egr1

Fgf2

Fgf7

Vim

Notch2

Hif1 $\alpha$

Jak2

Mmp9

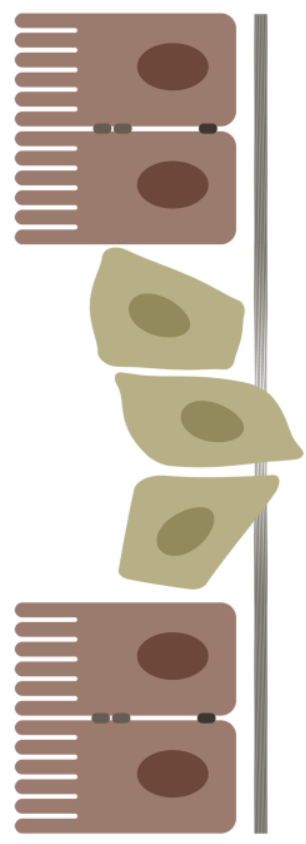

\section{Epiteliális-Mezenhimális Tranzíció}

31. ábra: A kísérletesen előidézett vastagbélgyulladás során azonosított, az EMT kialakításában résztvevő gének és gátló miRNS-ek közötti kapcsolat. A transzkriptóma analízis által azonosított EMT-t szabályozó miRNS-mRNS párok inverz expressziós mintázatát figyeltük meg a TNBS kezelt patkány vastagbelek gyulladt területein, ahol a gátló miRNS kifejeződése csökkent, ott targetjeik: az EMT-t előidéző gének kifejeződése szignifikánsan megemelkedett [115]. 
Ezeken felül olyan érett miRNS-ek mennyiségi változását is megmértük, amelyek prekurzorait az RNS-Seq során nem azonosítottuk, de ismert, hogy az EMT kialakításában szerepet játszó gének inhibítorai. Ilyen például a miR-199a, ami nemcsak a SNAI1 [103], hanem többek között az AXL gátlásában is részt vesz [81]. Inverz expressziós mintázatuknak nemcsak a TNBS kezelt patkány vastagbél gyulladt területin, hanem az IBD-s páciensek gyulladt szövetmintáiban is megfigyeltük (14., 15., 23., 24. és 30. ábra). Az EMT poszttranszkripcionális szabályozása szempontjából fontos miR-30 és miR-107 expressziója is szignifikánsan csökkent a gyulladt szövetrégiókban (30. ábra), melyek a VIM [140] és HIF1 $\alpha$ [93] inhibítorai. Az általunk vizsgált összes EMT-t indukáló miRNS-mRNS target pár expressziós mintázatára igaz, hogy ahol a gátló miRNS mennyisége lecsökken, ott a célmolekula kifejeződése megemelkedik (31. ábra).

Az in vivo vastagbélgyulladás modell teljes transzkriptóma vizsgálata során azonosított pri-miRNS-ek a gyulladás fékentartásában is jelentősek. A gyulladáskeltő citokinek és kemokinek inhibítoraként ismert miR-223 kifejeződése mind a patkány mind a humán vastagbélből származó mintákban pri- és érett miRNS szinten is megemelkedetten expresszálódott a gyulladt szövetekben (28. ábra). Az immunválasz során a vastagbélbe infiltráló immunsejtek által expresszált miR-223 a CXCL2 és CCL3 kemotaktikus fehérjéket kódoló gének [131] és a gyulladáskeltő TNF $\alpha$, IL1 $\beta$, IL6 és NLRP3 [107] gátlásán keresztül részt vesz a szöveti homeosztázis helyreállításában és a gyulladás féken tartásában.

Az IBD-s betegek tüneteinek enyhítésére gyakori terápiás célpont a $\mathrm{TNF} \alpha$, mely inaktív formában tárolódik a sejtekben mindaddig, amíg egy mátrix metalloproteináz, például az MMP13 enzimatikus hasítás révén ki nem alakítja belőle a funkcióképes alakot [19]. A TNBS kezelt gyulladt patkány vastagbél mintákban és az aktív stádiumban lévő IBD-s betegek gyulladt szöveteiben az emelkedett TNFa (12D. és 13C. ábra) expresszió, szignifikánsan megnövekedett MMP13 (29D-E. ábra) kifejeződéssel társult. Az MMP13 poszttranszkripcionális szabályozásában résztvevő miR-27b [137] kifejeződése ellenben szignifikánsan csökkent a patkány és IBD-s betegek gyulladt vastagbelében is (29. ábra). További vizsgálatokat követően a miR-27b potenciális terápiás célmolekulává válhat: amennyiben ektopikus túltermeltetésével az MMP13 mennyiségének és így a TNF $\alpha$ érésének 
csökkenését idézné elő. Az aktív TNFa szintjének csökkenése pedig a gyulladás visszaszorulását ereményezhetné a szövetekben.

Az IBD-s betegek életében váltakozó remissziós, azaz inaktív és relapszáló, vagyis aktív periódusok során a léziós és ép szövetrégiók elhelyezkedése változó a tápcsatorna mentén. Ez a váltakozás, a gyulladást és az EMT-t indukáló gének és azokat szabályozó miRNS-ek mennyiségének fluktuációját is jelenti a bélben. A hosszan elhúzódó gyulladás felboríthatja a kényes egyensúlyt ebben a bonyolultan szabályozott rendszerben, ami az IBDs betegkre jellemző magasabb vastagbélrák incidencia egyik tényezője is lehet. Másrészt a vérben keringő exoszómákban szállított vagy a vér alakos elemei által expresszált miRNSek [107] a tápcsatorna gyulladt és nem-gyulladt területein található sejtekben egyaránt kifejthetik gátló hatásukat, ami késleltetheti/megakadályozhatja a szöveti homeosztázis helyreállását.

A vastagbél szöveti felépítésében számos sejtalkotó részt vesz, melyek mindegyike más-más módon járul hozzá a homeosztázis fenntartásához és szükség esetén az immunválasz szabályozásához. Kísérleteink során a patkány és IBD-s betegek vastagbeléböl származó szövetminták gyulladt és nem-gyulladt területeit vizsgálva az adott szöveti régióra aktuálisan jellemző heterogén sejtpopulációban bekövetkező szignifikáns génexpressziós eltéréseket azonosítottuk. További kísérleteink során az egysejt izolálási technikák fejlödésének köszönhetően a sejttípusok elkülönített vizsgálatával szeretnénk az eddig feltárt transzkripciós mintázatot pontosítani, mellyel lehetőségünk nyílik a gyulladásos bélbetegségek molekuláris hátterének sokkal nagyobb felbontású és precízebb tanulmányozására.

A transzkriptóma analízis során detektált pri-miRNS-ek globális expresszió csökkenése a gyulladt vastagbélterületeken egy közös szabályozó mechanizmus meglétét feltételezi. Ezt a megfigyelést az érett miRNS-ek szintjén, miRNS-Seq módszer alkalmazásával szeretnék a továbbiakban vizsgálni. Abban az esetben, ha a fiziológiás körülmények között konstitutívan expresszálódó miRNS-ek folyamatos negatív szabályozás alatt tartják gyulladáskeltő targetjeiket, akkor a miRNS-ek kifejeződésének gyulladás során bekövetkező teljeskörü csökkenésével a célmolekulák egyszerre szabadulhatnak fel a gátlás 
alól és erőteljes gyulladásos választ indukálhatnak. A feltételezett folyamat átfogó hatását erősítiheti az a tény is, hogy egy miRNS számtalan mRNS szabályozásában is részt vehet, ami exponenciálisan növeli az érintett molekulák körét. Jövőbeli vizsgálataink tárgyát képzi a sejttípus specifikus transzkriptóma vizsgálat mellett ennek a lehetséges szabályozó mechanizmusnak a felderítése is. 


\section{7. ÖSSZEFOGLALÓ}

A gyulladásos bélbetegségekre (Inflammatory Bowel Disease; IBD) a tápcsatorna krónikus gyulladása jellemző, ami hasi fájdalommal és felszívódási zavarral társulva jelentősen csökkenti a betegek életminőségét; a hosszan fennálló gyulladás emellett növeli a vastagbélrák kockázatát. Multifaktoriális eredetü betegségként kialakulásának hátterében a genetikai tényezők mellett, a mikrobiális környezet és az életmód is szerepet játszik, azonban pontos pathomechanizmusa mindezidáig tisztázatlan. Az IBD-s betegek száma világszerte növekvő tendenciát mutat, ezért egyre fontosabb molekuláris hátterének megértése és újabb terápiás módszerek kifejlesztése.

Az IBD tanulmányozására általánosan elfogadott in vivo TNBS indukált patkány vastagbélgyulladás modellben a rektálisan befecskendezett 2,4,6-trinitrobenzol-szulfonsav (TNBS) a nyálkahártya integritását megbontva szórványosan elhelyezkedő léziókat hoz létre a vastagbélben, melyeket fenotípusosan ép szövetszakaszok váltanak, ahogy az az IBD-s betegek tápcsatornájában is megfigyelhető. A TNBS kezelést követően a makroszkópikusan jól megkülönböztethető gyulladt és nem-gyulladt régiók aránya állatonként eltérő, ami a hagyományos módon, azaz hosszanti irányba történő mintagyüjtés esetén heterogén mintapopulációt eredményezhet. A vastagbél különböző területei közötti transzkripcionális változások igazolására a TNBS kezelt patkányok gyulladt és nem-gyulladt szövetrégióiból is gyüjtöttünk mintákat. Ezeket a kezeletlen kontroll állatok vastagbeléből random módon izolált mintákhoz hasonlítottunk. Az in vivo rendszer hitelességének igazolására IBD-s betegekből származó mintákat alkalmaztunk: a modellhez hasonló módon az aktív stádiumban lévő betegek gyulladt és nem-gyulladt vastagbeléből is gyüjtöttünk mintákat, melyeket inaktív páciensekből származó minták génexpressziós értékeihez viszonyítottunk.

A TNBS kezelt patkányok gyulladt és látszólag ép szövetrégiói közötti globális génexpressziós különbségek megfigyelésére RNS-Seq módszer alkalmazásával teljes transzkriptóma vizsgálatot végeztünk. Az egyedi minták sajátos transzkripciós mintázatának in silico elvégzett többdimenziós skálázásával (Multidimensional scaling, MDS) a korábban makroszkópikus tulajdonságok alapján elkülönített minták molekuláris szinten is külön klasztereződtek: a kontroll, TNBS kezelt nem-gyulladt és a TNBS kezelt gyulladt 
csoportokba. A szignifikánsan változó transzkriptek hőtérképen való ábrázolása is alátámasztotta az MDS során megfigyelt jelentős különbséget a kezelt állatok gyulladt és nem-gyulladt vastagbélszakaszai között, ellenben a kontroll és nem-gyulladt minták hasonlónak bizonyultak globális génexpressziós szinten.

A mintacsoportok összehasonlítását követő útvonal elemzés révén megállapítottuk, hogy a legszignifikánsabban változó kanonikus útvonalak a gyulladt területeken az immunsejtek közötti kommunikációval, az immunsejtek toborzásával, a mintázat felismerő receptorok jelátvitelével, a gyulladásos válasz szabályozásával kapcsolatosak. Ezekkel összhangban szignifikánsan megemelkedett a gyulladáskeltő citokinek és kemokinek (pl.: Tnfa, Il6, Ccl3) kifejeződése a gyulladt szövetekben, míg a nem-gyulladt terülteken nem változott expressziójuk; ellenben a nyálkahártya védelmében szerepet játszó glikoziltranszferázok (pl.: A4gnt) és mucinok (pl.: Muc2) kifejeződése szignifikánsan megemelkedett az ép szövetekben.

A rágcsáló rendszerben azonosított génexpressziós eltérések relevanciáját IBD-s betegekből származó szövetminták vizsgálatával igazoltuk. A gyulladáskeltő citokinek kifejeződése - ahogy a patkány vastagbél minták esetén is láthattuk - szignifikánsan megemelkedett a páciensek gyulladt mintáiban, mind az inaktív, mind a relapszáló betegek nem-gyulladt mintáihoz viszonyítva. Miután az IBD patomechanizmusával már korábban kapcsolatba hozott gének expressziós mintázatát megvizsgáltuk a TNBS indukált patkány vastagbélgyulladás rendszerben, valamint IBD-s páciensekből származó szövetmintákon is igazoltuk a modell hitelességét, a betegség pathomechnaizmusában szerepet játszó új célmolekulák azonosítására törekedtünk.

A gyulladás negatív szabályozóiként ismert TAM receptorok közé tartozó Axl kifejeződése mRNS és fehérje szinten is jelentősen megemelkedett a TNBS kezelt patkányok gyulladt vastagbelében, ahogy az IBD-s betegek léziós vastagbél területein is szignifikánsan nőtt az AXL génexpressziója. A gyulladt területeken a pleiotróp hatású AXL negatív regulátorként és a fagocitózis elősegítése által támogathatja a szöveti homeosztázis helyreállítását; ellenben, mint az metasztázis képzésben szerepet játszó epiteliális - 
mezenhimális tranzíció (EMT) indúcere az IBD-s betegeknél gyakran kialakuló vastagbélrák kockázatát növelheti.

Az EMT során az epitélsejtek elveszítik epiteliális jellegüket, szoros sejt-sejt kapcsolataik fellazulnak és fokozódik a sejtek motilitása. Az EMT kialakításáért felelős fehérjéket kódoló gének kifejeződése szignifikásan megemelkedett a TNBS kezelt patkány és az IBD-s páciensek gyulladt vastagbelében egyaránt (FGF2, FGF7, EGR1, NOTCH2, JAK2, HIF1 $\alpha$, ZEB2, SNAI1, VIM, LOX, MMP9), míg az epiteliális marker CDH1 expressziója csökkent az azonos szövetrégiókban. Szintén az EMT-t támogatja a transzkriptóma analízis során azonosított pri-miRNS-ek és a belőlük képződő funkcióképes miRNS-ek globális expresszió csökkenése a gyulladt mintákban (pl.: miR-192, -200b, -375, -143), melyek a mezenhimális fenotípus kialakításában szerepet játszó gének inhibítorai.

Az RNS-Seq során azonosított pri-miRNS-k nemcsak az EMT-t indukáló gének, hanem más a gyulladásban szerepet játszó molekulák poszttranszkripcionális szabályozásában is részt vesznek. A gyulladás során szignifikánsan csökkent kifejeződésü pri-miR-27b és érett miR-27b célmolekulája az MMP13, ami a citoplazmában inaktív formában tárolt pro-TNF $\alpha$ érését segít. Az aktív TNF $\alpha$ pedig az IBD-s betegek tüneteinek enyhítésére kifejlesztett hatékony terápiás módszerek ismert targetje.

Munkánk során a TNBS által kiváltott vastagbélgyulladás rágcsáló modelljének használatakor alkalmazott módosított mintavételi eljárás tette lehetővé későbbi - az IBD molekuláris hátterének megértésében jelentős - megfigyeléseinket. Többek között megállapítottuk, hogy mind a TNBS kezelt patkány mind az aktív stádiumban lévő IBD-s páciensekből származó minták esetén: a gyulladt és nem-gyulladt vastagbélrégiók transzkriptómája szignifikánsan különbözik egymástól, ami nemcsak a fehérje kódoló mRNS-ek, hanem a miRNS-eket magukban hordozó pri-miRNS-ek kifejeződésében is megnyilvánult. Emellett fontos kiemelni, hogy a TNBS kezelt patkány és aktív IBD-s betegek nem-gyulladt szövetmintáinál tapasztalt génexpressziós mintázat nem csupán a gyulladásos válasz hiányát jelenti a gyulladt szakaszokhoz képest, hanem egy teljesen egyedi, a kontroll mintáktól is eltérő állapotot, ami a nyálkahártya védelmében szerepet játszó fehérjéket kódoló gének megemelkedett kifejeződésében nyilvánul meg. 
Eredményeink fényében a módosított mintavétel a TNBS által kiváltott kísérletes vastagbélgyulladás modell használatakor, és a TNBS kezelt állatok nem-gyulladt vastagbélszakaszainak vizsgálata, az IBD pathomechanizmusában eddig ismeretlen terápiás célmolekulák azonosítását teszi lehetővé. 


\section{SUMMARY}

Inflammatory Bowel Disease (IBD) is characterized by chronic inflammation along the gastrointestinal tract that associates with abdominal pain and malabsorption, which significantly reduce the quality of life. In addition, long lasting inflammation highly increases the risk of colorectal cancer of IBD patients. As a multifactorial disorder, besides genetic factors, microbial environment and lifestyle have great impact on IBD progression, but its exact etiology is still unclear. Understanding of the background molecular mechanism/s of IBD and development of novel therapies are important, because its incidence is increasing worldwide.

In the case of the widely used 2,4,6-trinitrobenzene sulfonic acid (TNBS) induced rat model of IBD the intracolonically administered TNBS destroys the integrity of intestinal epithelia and generates sporadically located lesions. Hence, inflamed and phenotypically normal or uninflamed tissue regions alternate along the colons, similarly to that observed in the digestive tract of IBD patients. After the TNBS treatment, the ratio of the morphologically distinguishable inflamed and uninflamed tissues is different among biological replicates. Consequently, the conventionally, namely longitudinally achieved sample collection from the colons may lead to heterogeneous sample population. To investigate the transcriptional changes after TNBS induction in different regions of the colon, we took samples from both the inflamed and the uninflamed tissue areas and compared them to untreated control samples. To prove the relevance of this in vivo system we validated the results on biopsies taken form IBD patients. Similarly to the model, we collected samples from the inflamed and uninflamed colon regions of patients in active/relapsing phase and compared them to samples derived from patient in inactive/remission phase.

To demonstrate global gene expression alteration between inflamed and uninflamed tissue regions following TNBS treatment, whole transcriptome analysis was performed by applying RNA-Seq. In silico performed multidimensional scaling (MDS) of individual transcriptomic data clustered samples into control, TNBS treated uninflamed and TNBS treated inflamed groups. In addition, heatmap representation of significantly altered transcripts confirmed differences between inflamed and uninflamed samples of TNBS treated 
animals; in contrast, control and uninflamed samples proved to be very similar at global transcriptomic level.

Functional analysis of our data sets revealed significant alteration of canonical pathways at the site of inflammation related to communication between immune cells, immune cell recruitment, signaling of pattern recognition receptors and regulation of inflammatory response. In line with this, the expression of proinflammatory cytokines and chemokines (e.g. Tnfa, Il6 and $\mathrm{Ccl} 3$ ) was induced in the inflamed tissues but remained unaltered in the uninflamed samples. Inversely, levels of glycosyltransferases (e.g. A4gnt) and mucins (e.g. Muc2) responsible for the protection of epithelia significantly increased in the TNBS treated uninflamed tissues.

We have next proved the relevance of our results obtained from rat model by using samples taken from IBD patients. The expression of proinflammatory cytokines significantly increased in the inflamed colons of patients as compared both to the inactive and to the activeuninflamed samples: these data corroborated those obtained from rat model. After the examination of expression pattern of genes with known impact on IBD pathogenesis in TNBS induced rat model of experimental colitis, and validation of our results in samples originated from IBD patients, we aimed to find novel target molecules associate with IBD.

Increasing evidence suggests that malfunction in the negative regulation of immune response leads to robust and prolonged inflammation. TAM receptors (TYRO3, AXL and MERTK) are known negative regulators of inflammation. Both mRNA and protein level of Axl significantly increased in the TNBS treated inflamed rat samples, in addition, we also detected elevated AXL gene expression in the colonic lesions of IBD patients. At the site of inflammation pleiotropic AXL may have a role as a negative regulator of innate immunity as well as phagocytic receptor in the reconstruction of tissue homeostasis. In addition, as the inducer of epithelial-mesenchymal transition (EMT) Axl may also enhance the risk of colorectal cancer in IBD patients.

Upon EMT epithelial cells lose their epithelial characteristics, cell-cell connections disintegrate and cells motility enhance. We have determined that the expression of EMT activating protein coding genes significantly increased both in the inflamed colon samples of 
TNBS treated rats as well as IBD patients (FGF2, FGF7, EGR1, NOTCH2, JAK2, HIF1 $\alpha$, ZEB2, SNAI1, VIM, LOX, MMP9), in contrast, the expression of the epithelial marker CDH1 decreased. During transcriptome analysis we observed the global reduction of primiRNAs and mature miRNAs: 27 out of 28 miRNAs (e.g. miR-192, -200b, -375, -143) showed downregulated expression profile. Most of these have targets among EMT inducing genes and their reduced expression may further enhance EMT in the inflamed colon tissues.

Besides the EMT inhibiting pri-miRNAs and miRNAs, we identified other primiRNAs with reduced expression that are related to posttranscriptional regulation of inflammatory genes. miR-27b is a known inhibitor of MMP13; the latter mediating the conversion of pro-TNF $\alpha$ into active form. In the inflamed colon samples we identified significantly decreased expression of pri- and mature miR-27b associated with increased MMP13 and TNF $\alpha$ mRNA levels. TNF $\alpha$ is a popular target of many inflammatory disorders including IBD: miR-27b may be a potential therapeutic target as its ectopic overexpression may indirectly reduce the level of TNF $\alpha$.

In summary, modified sample collection applied both for TNBS induced rat model of experimental colitis as well as for IBD patients facilitated the identification of unique gene and miRNA expression signatures which may help to better understand the molecular background of IBD. We have determined that the gene and miRNA expression pattern of inflamed and uninflamed colon tissues taken both from TNBS treated rats and IBD patients significantly differ from each other. In line with this, expression pattern of uninflamed samples represents a particular condition with specific molecular signature in which the expression of molecules responsible for the protection of the epithelium is significantly increased. Taken together, our results stress the importance and potential of the modified sample collection protocol which may facilitate the identification of novel molecules involved in IBD pathogenesis. 


\section{KÖSZÖNETNYILVÁNÍTÁS}

Szeretném megköszönni témavezetőm Dr. Nagy István támogatását és tanácsait, melyekkel hozzájárult elméleti és gyakorlati ismereteim bővítéséhez, az önálló kutatómunka elsajátításához. Köszönöm segítségét és türelmét, melyek nélkül dolgozatom nem készülhetett volna el.

Köszönöm Vörös Andreának a munkám során alkalmazott technikák elsajátításában nyújtott segítségét és baráti támogatását.

Hálával tartozom Cseklye Juditnak többek között az RNS-Seq könyvtárkészítében nyújtott segítségéért és Dr. Bálint Balázsnak a transzkriptóma analízis bioinformatikai feldolgozásáért.

Köszönöm a segítségét a Seqomics Kft. valamennyi dolgozójának.

Továbbá szeretném megköszönni Dr. Szalai Zitának és Dr. Varga Csabának az in vivo kísérleti rendszerben felhasznált állatok tartását, kezelését és a minták begyüjtését.

Köszönettel tartozom Dr. Kellermayer Zoltánnak, amiért a kísérleteinkben felhasznált IBD-s betegkből származó biopsziákat biztosította számunkra.

Köszönöm Dr. Hegedűs Zoltánnak, hogy segített az IPA alkalmazás használatának elsajátításában.

Hálásan köszönöm családom kitartó támogatását.

A dolgozat megvalósításához hozzájárult a TÁMOP 4.2.4.A/2-11-1-2012-0001 azonosító számú „Nemzeti Kiválóság Program - Hazai hallgatói, illetve kutatói személyi támogatást biztosító rendszer kidolgozása és müködtetése konvergencia program" címü kiemelt projekt, melyet az Európai Unió támogatásával, az Európai Szociális Alap társfinanszírozott. 


\section{IRODALOMJEGYZÉK}

1. Liu, J. és X. Cao, Cellular and molecular regulation of innate inflammatory responses. Cell Mol Immunol, 2016. 13(6): p. 711-721.

2. Akira, S., S. Uematsu, és O. Takeuchi, Pathogen recognition and innate immunity. Cell, 2006. 124(4): p. 783-801.

3. Hansen, J.D., L.N. Vojtech, és K.J. Laing, Sensing disease and danger: a survey of vertebrate PRRs and their origins. Dev Comp Immunol, 2011. 35(9): p. 886-97.

4. van Duin, D., R. Medzhitov, és A.C. Shaw, Triggering TLR signaling in vaccination. Trends Immunol, 2006. 27(1): p. 49-55.

5. Park, B.S. és J.O. Lee, Recognition of lipopolysaccharide pattern by TLR4 complexes. Exp Mol Med, 2013. 45: p. e66.

6. Ting, J.P., és mtsai The NLR gene family: a standard nomenclature. Immunity, 2008. 28(3): p. 285-7.

7. Elinav, E., és mtsai Regulation of the antimicrobial response by NLR proteins. Immunity, 2011. 34(5): p. 665-79.

8. Moore, C.B., és mtsai NLRX1 is a regulator of mitochondrial antiviral immunity. Nature, 2008. 451(7178): p. 573-7.

9. Schroder, K. és J. Tschopp, The inflammasomes. Cell, 2010. 140(6): p. 821-32.

10. Baroja-Mazo, A., és mtsai The NLRP3 inflammasome is released as a particulate danger signal that amplifies the inflammatory response. Nat Immunol, 2014. 15(8): p. 738-48.

11. Simard, J.C., és mtsai S100A8 and S100A9 induce cytokine expression and regulate the NLRP3 inflammasome via ROS-dependent activation of NF-kappaB(1.). PLoS One, 2013. 8(8): p. e72138.

12. Anand, P.K., és mtsai NLRP6 negatively regulates innate immunity and host defence against bacterial pathogens. Nature, 2012. 488(7411): p. 389-93.

13. Elinav, E., és mtsai NLRP6 inflammasome regulates colonic microbial ecology and risk for colitis. Cell, 2011. 145(5): p. 745-57.

14. Ogura, Y., és mtsai $A$ frameshift mutation in NOD2 associated with susceptibility to Crohn's disease. Nature, 2001. 411(6837): p. 603-6.

15. Hugot, J.P., és mtsai Association of NOD2 leucine-rich repeat variants with susceptibility to Crohn's disease. Nature, 2001. 411(6837): p. 599-603.

16. Jamontt, J., és mtsai Nucleotide-binding oligomerization domain 2 signaling promotes hyperresponsive macrophages and colitis in IL-10-deficient mice. J Immunol, 2013. 190(6): p. 2948-58.

17. Hunter, C.A. és S.A. Jones, IL-6 as a keystone cytokine in health and disease. Nat Immunol, 2015. 16(5): p. 448-57.

18. Feghali, C.A. és T.M. Wright, Cytokines in acute and chronic inflammation. Front Biosci, 1997. 2: p. d12-26.

19. Vandenbroucke, R.E., és mtsai Matrix metalloproteinase 13 modulates intestinal epithelial barrier integrity in inflammatory diseases by activating TNF. EMBO Mol Med, 2013. 5(7): p. 1000-16.

20. Sonnenberg, G.F. és D. Artis, Innate lymphoid cells in the initiation, regulation and resolution of inflammation. Nat Med, 2015. 21(7): p. 698-708. 
21. Papalexi, E. és R. Satija, Single-cell RNA sequencing to explore immune cell heterogeneity. Nat Rev Immunol, 2018. 18(1): p. 35-45.

22. Rivera, A., és mtsai Innate cell communication kick-starts pathogen-specific immunity. Nat Immunol, 2016. 17(4): p. 356-63.

23. Pu, Q. és C. Yu, Glycosyltransferases, glycosylation and atherosclerosis. Glycoconj J, 2014. 31(9): p. 605-11.

24. Ma, B., J.L. Simala-Grant, és D.E. Taylor, Fucosylation in prokaryotes and eukaryotes. Glycobiology, 2006. 16(12): p. 158R-184R.

25. Nakayama, F., és mtsai CD15 expression in mature granulocytes is determined by alpha 1,3-fucosyltransferase IX, but in promyelocytes and monocytes by alpha 1,3fucosyltransferase IV. J Biol Chem, 2001. 276(19): p. 16100-6.

26. Ley, K., és mtsai Getting to the site of inflammation: the leukocyte adhesion cascade updated. Nat Rev Immunol, 2007. 7(9): p. 678-89.

27. Martin-Belmonte, F. és M. Perez-Moreno, Epithelial cell polarity, stem cells and cancer. Nat Rev Cancer, 2011. 12(1): p. 23-38.

28. Graham, D.K., és mtsai The TAM family: phosphatidylserine sensing receptor tyrosine kinases gone awry in cancer. Nat Rev Cancer, 2014. 14(12): p. 769-85.

29. Rothlin, C.V., és mtsai TAM receptors are pleiotropic inhibitors of the innate immune response. Cell, 2007. 131(6): p. 1124-36.

30. Zagorska, A., és mtsai Diversification of TAM receptor tyrosine kinase function. Nat Immunol, 2014. 15(10): p. 920-8.

31. Chan, P.Y., és mtsai The TAM family receptor tyrosine kinase TYRO3 is a negative regulator of type 2 immunity. Science, 2016. 352(6281): p. 99-103.

32. Lemke, G. és C.V. Rothlin, Immunobiology of the TAM receptors. Nat Rev Immunol, 2008. 8(5): p. 327-36.

33. Rothlin, C.V. és G. Lemke, TAM receptor signaling and autoimmune disease. Curr Opin Immunol, 2010. 22(6): p. 740-6.

34. Parks, W.C., C.L. Wilson, és Y.S. Lopez-Boado, Matrix metalloproteinases as modulators of inflammation and innate immunity. Nat Rev Immunol, 2004. 4(8): p. 617-29.

35. Van Lint, P. és C. Libert, Chemokine and cytokine processing by matrix metalloproteinases and its effect on leukocyte migration and inflammation. J Leukoc Biol, 2007. 82(6): p. 137581.

36. Okumura, R. és K. Takeda, Roles of intestinal epithelial cells in the maintenance of gut homeostasis. Exp Mol Med, 2017. 49(5): p. e338.

37. Corfield, A.P., Mucins: a biologically relevant glycan barrier in mucosal protection. Biochim Biophys Acta, 2015. 1850(1): p. 236-52.

38. Johansson, M.E., J.M. Larsson, és G.C. Hansson, The two mucus layers of colon are organized by the MUC2 mucin, whereas the outer layer is a legislator of host-microbial interactions. Proc Natl Acad Sci U S A, 2011. 108 Suppl 1: p. 4659-65.

39. Maynard, C.L., és mtsai Reciprocal interactions of the intestinal microbiota and immune system. Nature, 2012. 489(7415): p. 231-41.

40. Larsson, J.M., és mtsai Altered O-glycosylation profile of MUC2 mucin occurs in active ulcerative colitis and is associated with increased inflammation. Inflamm Bowel Dis, 2011. 17(11): p. 2299-307.

41. Goto, Y., és mtsai Innate lymphoid cells regulate intestinal epithelial cell glycosylation. Science, 2014. 345(6202): p. 1254009. 
42. Pickard, J.M., és mtsai Rapid fucosylation of intestinal epithelium sustains host-commensal symbiosis in sickness. Nature, 2014. 514(7524): p. 638-41.

43. Saleh, M. és G. Trinchieri, Innate immune mechanisms of colitis and colitis-associated colorectal cancer. Nat Rev Immunol, 2011. 11(1): p. 9-20.

44. Silva, L.C., L.C. Ortigosa, és G. Benard, Anti-TNF-alpha agents in the treatment of immunemediated inflammatory diseases: mechanisms of action and pitfalls. Immunotherapy, 2010. 2(6): p. 817-33.

45. El-Gabalawy, H., L.C. Guenther, és C.N. Bernstein, Epidemiology of immune-mediated inflammatory diseases: incidence, prevalence, natural history, and comorbidities. J Rheumatol Suppl, 2010. 85: p. 2-10.

46. Podolsky, D.K., Inflammatory bowel disease (1). N Engl J Med, 1991. 325(13): p. 928-37.

47. Liu, T.C. és T.S. Stappenbeck, Genetics and Pathogenesis of Inflammatory Bowel Disease. Annu Rev Pathol, 2016. 11: p. 127-48.

48. de Souza, H.S.P., C. Fiocchi, és D. Iliopoulos, The IBD interactome: an integrated view of aetiology, pathogenesis and therapy. Nat Rev Gastroenterol Hepatol, 2017. 14(12): p. 739749.

49. Weimers, P. és P. Munkholm, The Natural History of IBD: Lessons Learned. Curr Treat Options Gastroenterol, 2018.

50. Lakatos, L., és mtsai Striking elevation in incidence and prevalence of inflammatory bowel disease in a province of western Hungary between 1977-2001. World J Gastroenterol, 2004. 10(3): p. 404-9.

51. Kurti, Z., és mtsai Nationwide prevalence and drug treatment practices of inflammatory bowel diseases in Hungary: A population-based study based on the National Health Insurance Fund database. Dig Liver Dis, 2016. 48(11): p. 1302-1307.

52. Burisch, J. és P. Munkholm, The epidemiology of inflammatory bowel disease. Scand J Gastroenterol, 2015. 50(8): p. 942-51.

53. Barcellos-Hoff, M.H., D. Lyden, és T.C. Wang, The evolution of the cancer niche during multistage carcinogenesis. Nat Rev Cancer, 2013. 13(7): p. 511-8.

54. Elinav, E., és mtsai Inflammation-induced cancer: crosstalk between tumours, immune cells and microorganisms. Nat Rev Cancer, 2013. 13(11): p. 759-71.

55. Balkwill, F. és A. Mantovani, Inflammation and cancer: back to Virchow? Lancet, 2001. 357(9255): p. 539-45.

56. Coussens, L.M. és Z. Werb, Inflammation and cancer. Nature, 2002. 420(6917): p. 860-7.

57. Grivennikov, S.I., F.R. Greten, és M. Karin, Immunity, inflammation, and cancer. Cell, 2010. 140(6): p. 883-99.

58. Taniguchi, K. és M. Karin, NF-kappaB, inflammation, immunity and cancer: coming of age. Nat Rev Immunol, 2018.

59. Lamouille, S., J. Xu, és R. Derynck, Molecular mechanisms of epithelial-mesenchymal transition. Nat Rev Mol Cell Biol, 2014. 15(3): p. 178-96.

60. Gjerdrum, C., és mtsai $A x l$ is an essential epithelial-to-mesenchymal transition-induced regulator of breast cancer metastasis and patient survival. Proc Natl Acad Sci U S A, 2010. 107(3): p. 1124-9.

61. Vuoriluoto, K., és mtsai Vimentin regulates EMT induction by Slug and oncogenic H-Ras and migration by governing Axl expression in breast cancer. Oncogene, 2011. 30(12): p. 1436-48. 
62. O'Bryan, J.P., és mtsai axl, a transforming gene isolated from primary human myeloid leukemia cells, encodes a novel receptor tyrosine kinase. Mol Cell Biol, 1991. 11(10): p. 5016-31.

63. Gay, C.M., K. Balaji, és L.A. Byers, Giving AXL the axe: targeting AXL in human malignancy. Br J Cancer, 2017. 116(4): p. 415-423.

64. Asiedu, M.K., és mtsai $A X L$ induces epithelial-to-mesenchymal transition and regulates the function of breast cancer stem cells. Oncogene, 2014. 33(10): p. 1316-24.

65. Wang, Z., és mtsai The role of Notch signaling pathway in epithelial-mesenchymal transition (EMT) during development and tumor aggressiveness. Curr Drug Targets, 2010. 11(6): p. 745-51.

66. Rankin, E.B., és mtsai Direct regulation of GAS6/AXL signaling by HIF promotes renal metastasis through SRC and MET. Proc Natl Acad Sci U S A, 2014. 111(37): p. 13373-8.

67. Peng, G. és Y. Liu, Hypoxia-inducible factors in cancer stem cells and inflammation. Trends Pharmacol Sci, 2015. 36(6): p. 374-83.

68. Mohammadi, A., B. Mansoori, és B. Baradaran, The role of microRNAs in colorectal cancer. Biomed Pharmacother, 2016. 84: p. 705-713.

69. Bartel, D.P., MicroRNAs: genomics, biogenesis, mechanism, and function. Cell, 2004. 116(2): p. 281-97.

70. Sontheimer, E.J., Assembly and function of RNA silencing complexes. Nat Rev Mol Cell Biol, 2005. 6(2): p. 127-38.

71. Davis-Dusenbery, B.N. és A. Hata, Mechanisms of control of microRNA biogenesis. J Biochem, 2010. 148(4): p. 381-92.

72. Winter, J., és mtsai Many roads to maturity: microRNA biogenesis pathways and their regulation. Nat Cell Biol, 2009. 11(3): p. 228-34.

73. Vidigal, J.A. és A. Ventura, The biological functions of miRNAs: lessons from in vivo studies. Trends Cell Biol, 2015. 25(3): p. 137-47.

74. Guo, X., és mtsai The microRNA-processing enzymes: Drosha and Dicer can predict prognosis of nasopharyngeal carcinoma. J Cancer Res Clin Oncol, 2012. 138(1): p. 49-56.

75. Wang, X., és mtsai $c-M y c$ modulates microRNA processing via the transcriptional regulation of Drosha. Sci Rep, 2013. 3: p. 1942.

76. Su, X., és mtsai TAp63 suppresses metastasis through coordinate regulation of Dicer and miRNAs. Nature, 2010. 467(7318): p. 986-90.

77. Rupaimoole, R. és F.J. Slack, MicroRNA therapeutics: towards a new era for the management of cancer and other diseases. Nat Rev Drug Discov, 2017. 16(3): p. 203-222.

78. Misso, G., és mtsai Mir-34: a new weapon against cancer? Mol Ther Nucleic Acids, 2014. 3 : p. e194.

79. Giles, K.M., és mtsai AxI mediates acquired resistance of head and neck cancer cells to the epidermal growth factor receptor inhibitor erlotinib. Mol Cancer Ther, 2013. 12(11): p. 2541-58.

80. Cho, C.Y., és mtsai Negative feedback regulation of AXL by miR-34a modulates apoptosis in lung cancer cells. RNA, 2016. 22(2): p. 303-15.

81. Mudduluru, G., és mtsai Regulation of Axl receptor tyrosine kinase expression by miR-34a and miR-199a/b in solid cancer. Oncogene, 2011. 30(25): p. 2888-99.

82. Zhu, H.Y., és mtsai Peroxisome proliferator-activated receptor-gamma agonist troglitazone suppresses transforming growth factor-beta1 signalling through miR-92b upregulation- 
inhibited Axl expression in human keloid fibroblasts in vitro. Am J Transl Res, 2016. 8(8): p. 3460-70.

83. Belfiore, A., M. Genua, és R. Malaguarnera, PPAR-gamma agonists and their effects on IGF-I receptor signaling: Implications for cancer. PPAR Res, 2009. 2009: p. 830501.

84. Zaravinos, A., The Regulatory Role of MicroRNAs in EMT and Cancer. J Oncol, 2015. 2015: p. 865816.

85. Bracken, C.P., és mtsai A double-negative feedback loop between ZEB1-SIP1 and the microRNA-200 family regulates epithelial-mesenchymal transition. Cancer Res, 2008. 68(19): p. 7846-54.

86. Kong, W., és mtsai Upregulation of miRNA-155 promotes tumour angiogenesis by targeting $\mathrm{VHL}$ and is associated with poor prognosis and triple-negative breast cancer. Oncogene, 2014. 33(6): p. 679-89.

87. Wu, S.Y., és mtsai A miR-192-EGR1-HOXB9 regulatory network controls the angiogenic switch in cancer. Nat Commun, 2016. 7: p. 11169.

88. Rokavec, M., W. Wu, és J.L. Luo, IL6-mediated suppression of miR-200c directs constitutive activation of inflammatory signaling circuit driving transformation and tumorigenesis. Mol Cell, 2012. 45(6): p. 777-89.

89. Liu, Y., és mtsai miR-375 targets the $p 53$ gene to regulate cellular response to ionizing radiation and etoposide in gastric cancer cells. DNA Repair (Amst), 2013. 12(9): p. 741-50.

90. Zhang, N., és mtsai MicroRNA 375 mediates the signaling pathway of corticotropinreleasing factor (CRF) regulating pro-opiomelanocortin (POMC) expression by targeting mitogen-activated protein kinase 8. J Biol Chem, 2013. 288(15): p. 10361-73.

91. Ding, L., és mtsai MiR-375 frequently downregulated in gastric cancer inhibits cell proliferation by targeting JAK2. Cell Res, 2010. 20(7): p. 784-93.

92. Xu, Y., és mtsai Snail-regulated MiR-375 inhibits migration and invasion of gastric cancer cells by targeting JAK2. PLoS One, 2014. 9(7): p. e99516.

93. Yamakuchi, M., és mtsai P53-induced microRNA-107 inhibits HIF-1 and tumor angiogenesis. Proc Natl Acad Sci U S A, 2010. 107(14): p. 6334-9.

94. Chen, L., és mtsai MicroRNA-107 inhibits U87 glioma stem cells growth and invasion. Cell Mol Neurobiol, 2013. 33(5): p. 651-7.

95. Chen, L., és mtsai P53-induced microRNA-107 inhibits proliferation of glioma cells and down-regulates the expression of CDK6 and Notch-2. Neurosci Lett, 2013. 534: p. 327-32.

96. Tsujimura, K., és mtsai miR-199a Links MeCP2 with mTOR Signaling and Its Dysregulation Leads to Rett Syndrome Phenotypes. Cell Rep, 2015. 12(11): p. 1887-901.

97. Rane, S., és mtsai Downregulation of miR-199a derepresses hypoxia-inducible factor1 alpha and Sirtuin 1 and recapitulates hypoxia preconditioning in cardiac myocytes. Circ Res, 2009. 104(7): p. 879-86.

98. Raimondi, L., és mtsai Targeting of multiple myeloma-related angiogenesis by miR-199a$5 p$ mimics: in vitro and in vivo anti-tumor activity. Oncotarget, 2014. 5(10): p. 3039-54.

99. Morita, K., és mtsai Relevance of microRNA-18a and microRNA-199a-5p to hepatocellular carcinoma recurrence after living donor liver transplantation. Liver Transpl, 2016. 22(5): p. 665-76.

100. Ding, G., és mtsai MiR-199a suppresses the hypoxia-induced proliferation of non-small cell lung cancer cells through targeting HIF1alpha. Mol Cell Biochem, 2013. 384(1-2): p. 17380 . 
101. Jia, X.Q., és mtsai Lentivirus-mediated overexpression of microRNA-199a inhibits cell proliferation of human hepatocellular carcinoma. Cell Biochem Biophys, 2012. 62(1): p. 237-44.

102. Hassan, T., és mtsai miR-199a-5p silencing regulates the unfolded protein response in chronic obstructive pulmonary disease and alpha1-antitrypsin deficiency. Am J Respir Crit Care Med, 2014. 189(3): p. 263-73.

103. Suzuki, T., és mtsai Suppression of the TGF-beta1-induced protein expression of SNAI1 and $N$-cadherin by miR-199a. Genes Cells, 2014. 19(9): p. 667-75.

104. O'Connell, R.M., D.S. Rao, és D. Baltimore, microRNA regulation of inflammatory responses. Annu Rev Immunol, 2012. 30: p. 295-312.

105. Liu, G. és E. Abraham, MicroRNAs in immune response and macrophage polarization. Arterioscler Thromb Vasc Biol, 2013. 33(2): p. 170-7.

106. Zhuang, G., és mtsai $A$ novel regulator of macrophage activation: miR-223 in obesityassociated adipose tissue inflammation. Circulation, 2012. 125(23): p. 2892-903.

107. Poon, K.S., és mtsai Plasma exosomal miR-223 expression regulates inflammatory responses during cardiac surgery with cardiopulmonary bypass. Sci Rep, 2017. 7(1): p. 10807.

108. Jopling, C.L., és mtsai Modulation of hepatitis C virus RNA abundance by a liver-specific MicroRNA. Science, 2005. 309(5740): p. 1577-81.

109. Robinson, M.D., D.J. McCarthy, és G.K. Smyth, edgeR: a Bioconductor package for differential expression analysis of digital gene expression data. Bioinformatics, 2010. 26(1): p. 139-40.

110. Robinson, M.D. és A. Oshlack, A scaling normalization method for differential expression analysis of RNA-seq data. Genome Biol, 2010. 11(3): p. R25.

111. Ritchie, M.E., és mtsai limma powers differential expression analyses for RNA-sequencing and microarray studies. Nucleic Acids Res, 2015. 43(7): p. e47.

112. Morris, G.P., és mtsai Hapten-induced model of chronic inflammation and ulceration in the rat colon. Gastroenterology, 1989. 96(3): p. 795-803.

113. Goyal, N., és mtsai Animal models of inflammatory bowel disease: a review. Inflammopharmacology, 2014. 22(4): p. 219-33.

114. Brenna, O., és mtsai Relevance of TNBS-colitis in rats: a methodological study with endoscopic, histologic and Transcriptomic [corrected] characterization and correlation to IBD. PLoS One, 2013. 8(1): p. e54543.

115. Boros, E., és mtsai Specific Gene- and MicroRNA-Expression Pattern Contributes to the Epithelial to Mesenchymal Transition in a Rat Model of Experimental Colitis. Mediators Inflamm, 2017. 2017: p. 5257378.

116. Lamine, F., és mtsai Colonic responses to Lactobacillus farciminis treatment in trinitrobenzene sulphonic acid-induced colitis in rats. Scand J Gastroenterol, 2004. 39(12): p. $1250-8$.

117. Walsh, D., és mtsai Pattern recognition receptors--molecular orchestrators of inflammation in inflammatory bowel disease. Cytokine Growth Factor Rev, 2013. 24(2): p. 91-104.

118. Benko, S., D.J. Philpott, és S.E. Girardin, The microbial and danger signals that activate Nod-like receptors. Cytokine, 2008. 43(3): p. 368-73.

119. Kempster, S.L., és mtsai Developmental control of the NIrp6 inflammasome and a substrate, IL-18, in mammalian intestine. Am J Physiol Gastrointest Liver Physiol, 2011. 300(2): p. G253-63. 
120. Sanjabi, S., és mtsai Anti-inflammatory and pro-inflammatory roles of TGF-beta, IL-10, and IL-22 in immunity and autoimmunity. Curr Opin Pharmacol, 2009. 9(4): p. 447-53.

121. Couper, K.N., D.G. Blount, és E.M. Riley, IL-10: the master regulator of immunity to infection. J Immunol, 2008. 180(9): p. 5771-7.

122. Yoshimura, A., T. Naka, és M. Kubo, SOCS proteins, cytokine signalling and immune regulation. Nat Rev Immunol, 2007. 7(6): p. 454-65.

123. Rosenstiel, P., és mtsai Regulation of DMBT1 via NOD2 and TLR4 in intestinal epithelial cells modulates bacterial recognition and invasion. J Immunol, 2007. 178(12): p. 8203-11.

124. Zhang, M.X., és mtsai Immunohistochemical demonstration of alpha1,4-Nacetylglucosaminy/transferase that forms GlcNAcalpha1,4Galbeta residues in human gastrointestinal mucosa. J Histochem Cytochem, 2001. 49(5): p. 587-96.

125. Dall'Olio, F., és mtsai The expanding roles of the $S d(a) / C a d$ carbohydrate antigen and its cognate glycosy/transferase B4GALNT2. Biochim Biophys Acta, 2014. 1840(1): p. 443-53.

126. Groux-Degroote, S., és mtsai B4GALNT2 gene expression controls the biosynthesis of Sda and sialyl Lewis $X$ antigens in healthy and cancer human gastrointestinal tract. Int J Biochem Cell Biol, 2014. 53: p. 442-9.

127. Terahara, K., és mtsai Distinct fucosylation of M cells and epithelial cells by Fut1 and Fut2, respectively, in response to intestinal environmental stress. Biochem Biophys Res Commun, 2011. 404(3): p. 822-8.

128. Yang, X., és mtsai Overexpression of fucosyltransferase IV in A431 cell line increases cell proliferation. Int J Biochem Cell Biol, 2007. 39(9): p. 1722-30.

129. Yang, X., S. Liu, és Q. Yan, Role of fucosyltransferase IV in epithelial-mesenchymal transition in breast cancer cells. Cell Death Dis, 2013. 4: p. e735.

130. Wang, H., és mtsai Circulating MicroRNA223 is a New Biomarker for Inflammatory Bowel Disease. Medicine (Baltimore), 2016. 95(5): p. e2703.

131. Johnnidis, J.B., és mtsai Regulation of progenitor cell proliferation and granulocyte function by microRNA-223. Nature, 2008. 451(7182): p. 1125-9.

132. Dorhoi, A., és mtsai MicroRNA-223 controls susceptibility to tuberculosis by regulating lung neutrophil recruitment. J Clin Invest, 2013. 123(11): p. 4836-48.

133. Li, W., és mtsai miR-27b-3p, miR-181a-1-3p, and miR-326-5p are involved in the inhibition of macrophage activation in chronic liver injury. J Mol Med (Berl), 2017. 95(10): p. 10911105.

134. Zhang, M., és mtsai MicroRNA-27a/b regulates cellular cholesterol efflux, influx and esterification/hydrolysis in THP-1 macrophages. Atherosclerosis, 2014. 234(1): p. 54-64.

135. Chuturgoon, A.A., A. Phulukdaree, és D. Moodley, Fumonisin B(1) modulates expression of human cytochrome P450 1 b1 in human hepatoma (Hepg2) cells by repressing Mir-27b. Toxicol Lett, 2014. 227(1): p. 50-5.

136. Tsuchiya, Y., és mtsai MicroRNA regulates the expression of human cytochrome P450 $1 B 1$. Cancer Res, 2006. 66(18): p. 9090-8.

137. Akhtar, N., és mtsai MicroRNA-27b regulates the expression of matrix metalloproteinase 13 in human osteoarthritis chondrocytes. Arthritis Rheum, 2010. 62(5): p. 1361-71.

138. Siemens, H., és mtsai miR-34 and SNAIL form a double-negative feedback loop to regulate epithelial-mesenchymal transitions. Cell Cycle, 2011. 10(24): p. 4256-71.

139. Yu, J., és mtsai miR-300 inhibits epithelial to mesenchymal transition and metastasis by targeting Twist in human epithelial cancer. Mol Cancer, 2014. 13: p. 121. 
140. Liu, Z., és mtsai RUNX3 regulates vimentin expression via miR-30a during epithelialmesenchymal transition in gastric cancer cells. J Cell Mol Med, 2014. 18(4): p. 610-23.

141. Liu, W., és mtsai MicroRNA-27b functions as a new inhibitor of ovarian cancer-mediated vasculogenic mimicry through suppression of VE-cadherin expression. RNA, 2017. 23(7): p. 1019-1027.

142. Bernstein, C.N. és F. Shanahan, Disorders of a modern lifestyle: reconciling the epidemiology of inflammatory bowel diseases. Gut, 2008. 57(9): p. 1185-91. 


\section{FÜGGELÉK}

F1. ábra: A gyulladás szabályozásában szerepet játszó molekulák változása TNBS kezelést követően. A dolgozatban említett fontosabb gének RNS-Seq által azonosított génexpressziós mintázata a nem-gyulladt vs. kontroll (NGY-GY), gyulladt vs. kontroll (GY-K) és a gyulladt vs. nemgyulladt (GY-NGY) minták összehasonlítása során. Az értékek logaritmikus skálán kifejezett fold change, azaz $\log (\mathrm{FC})$ értékek, a szignifikáns változás mértékét $>1$ vagy $<-1$ teljesülése esetén színskála jelöli, a piros a növekedés, a kék a génexpresszió csökkenést szimbolizálja; a szürke a nemszignifikáns értékeket jelöli.

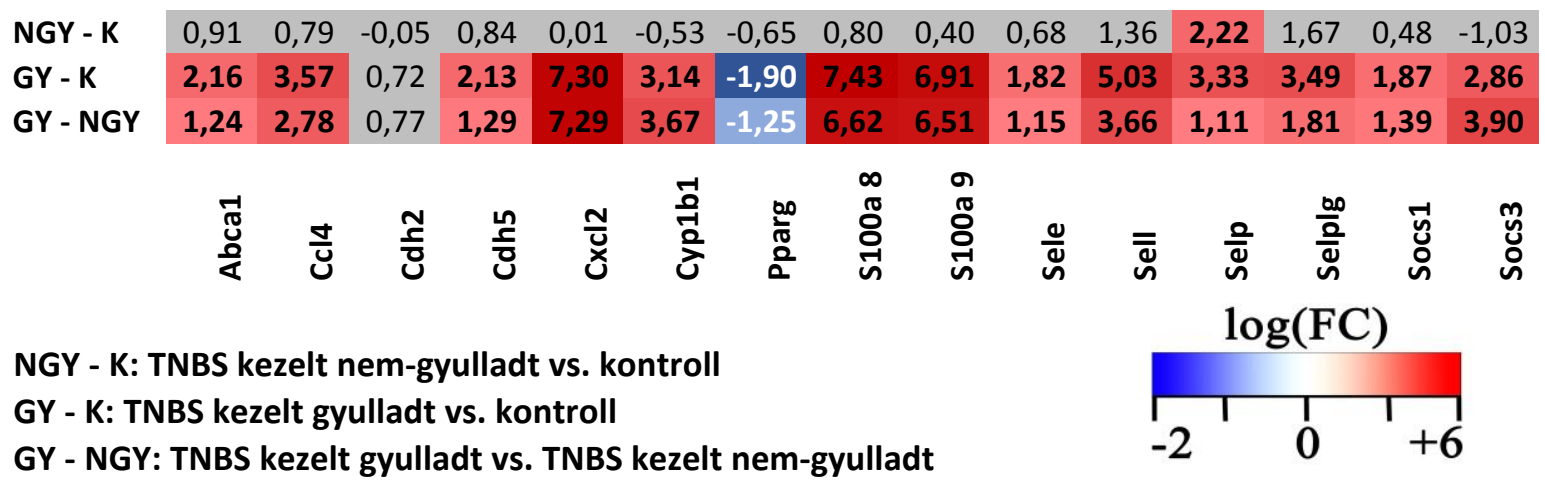

